\title{
Escrito com o Corpo: investigações sobre a escuta e o gesto musical
}

Bernardo Guedes Nogueira Gomes de Barros

Orientador: Prof. Dr. Marcos Branda Lacerda

Universidade de São Paulo - São Paulo

Outubro/2010 


\title{
Escrito com o Corpo: investigações sobre a escuta e o gesto musical
}

\author{
Bernardo Guedes Nogueira Gomes de Barros
}

Orientador: Prof. Dr. Marcos Branda Lacerda

Dissertação apresentada ao Programa de Pós-Graduação em Música - ECA-USP, como parte dos requisitos para obtenção do título de Mestre em Música. Original disponível na Unidade que aloja o Programa.

Universidade de São Paulo - São Paulo

Outubro/2010 


\section{Agradecimentos}

ao meu orientador Prof. Dr. Marcos Branda Lacerda, por acreditar em mim e na pesquisa, pela paciência e ajuda inestimável;

à minha companheira Fernanda Aoki, por seu apoio emocional, trocas de ideias e ajuda, sem você nada disso seria possível;

aos meus pais, pelo apoio e amor em todos os momentos;

aos meu irmãos Joaquim e Geraldo, pela amizade;

ao compositor Frank Cox, pela troca de e-mails e pelos textos gentilmente cedidos; aos compositores Sílvio Ferraz e Fernando Iazzetta, que colaboraram com importantes críticas e contribuições na qualificação da pesquisa;

ao compositor Richard Barrett, pela ajuda, incentivo e sobretudo pela obra musical inspiradora;

à editora PETERs, pelo empréstimo de material;

à CAPES/CNPQ pelo apoio financeiro de grande ajuda na qualidade do trabalho, e ao seu papel importantíssimo para a construção de um ambiente propício à geração de conhecimento e crítica em nosso país. 


\section{Resumo}

O estudo aborda o papel do gesto e da corporalidade na composição, interpretação e percepção musical. Investigaremos obras de diferentes épocas e estilos, porém nosso esforço principal se concentra na corporalidade e do gesto para a interpretação e composição no contexto da música contemporânea. Duas obras são especialmente analisadas, as Variações op.27 de Anton Webern e Air de Richard Barrett. 


\begin{abstract}
The research approaches the role of gesture and corporality in musical composition, performance and perception. We will discuss works from different periods and styles, although our main effort focuses on corporality and musical gesture in contemporary music composition and performance. Anton Webern's Variations op.27 and Richard Barrett's Air are specially analyzed.
\end{abstract}




\section{Sumário}

Lista de Figuras v v

Lista de Tabelas vii

\begin{tabular}{lll}
\hline 1 & Introdução & 1
\end{tabular}

\begin{tabular}{|l|l|}
\hline Gesto e Escritura & 6
\end{tabular}

$\begin{array}{lll}2 & \text { Gesto e Escuta } & 7\end{array}$

2.1 Movimento . . . . . . . . . . . . . . . . . . . . . 8

2.2 Gesto e movimento não são sinônimos . . . . . . . . . . . . . . . . . . . . $\quad 8$

2.3 Gesto físico e sonoro $\ldots \ldots \ldots \ldots$

2.4 Movimento e Significado . . . . . . . . . . . . . . . . . . . 10

2.5 Unidade Morfológica $\ldots \ldots \ldots$

$2.6 \quad$ Figura e Gesto . . . . . . . . . . . . . . . . . . . . . . . . . . . . . . . 14

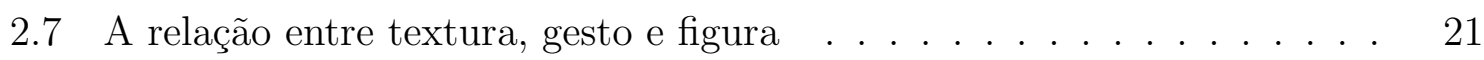

3 Aspectos da Escuta Musical 24

3.1 Quatro aspectos fundamentais da escuta musical . . . . . . . . . . . . . 27

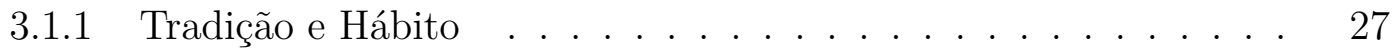

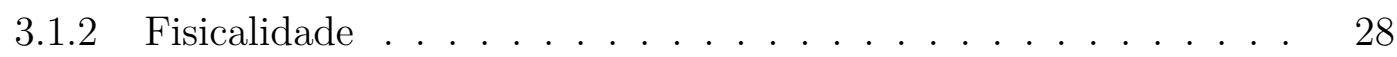

$3.1 .3 \quad$ Estruturalidade . . . . . . . . . . . . . . . . . . . . . . . . . 29

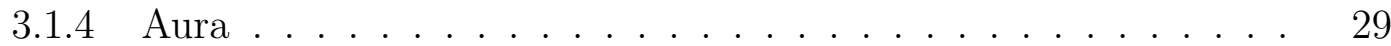


3.2 Desmantelamento da técnica instrumental . . . . . . . . . . . . . . . 30

4 A Escrita Corporal 36

4.1 Notação $\ldots \ldots \ldots \ldots$. . . . . . . . . . . . . . . . . . 36

4.2 Parâmetros "secundários" $\ldots \ldots \ldots$

4.3 Notação Prescritiva . . . . . . . . . . . . . . . . . . . . . . . . . . . 39

$4.3 .1 \quad$ Notação descritiva ou notação de resultado . . . . . . . . . . . . 39

4.3 .2 Notação prescritiva ou notação de ação . . . . . . . . . . . . . . 42

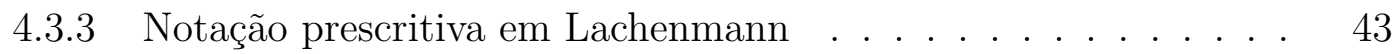

4.4 Consideraçõs finais: escritura musical e o corpo . . . . . . . . . . . . . 47

II Análises Musicais $\quad 48$

5 Fisicalidade em obras para teclado 50

5.1 Domenico Scarlatti . . . . . . . . . . . . . . . . . 50

5.2 Frédéric Chopin . . . . . . . . . . . . . . . . . . 53

5.3 Michael Finnissy $\ldots \ldots \ldots \ldots$. . . . . . . . . . . . . 56

5.4 Anton Webern . . . . . . . . . . . . . . . . . . . . . . . . . 58

5.5 Considerações finais $\ldots \ldots \ldots$. . . . . . . . . . . 70

\begin{tabular}{lll}
\hline Air de Richard Barrett & 71
\end{tabular}

6.1 Introdução . . . . . . . . . . . . . . . . . . . . . . 71

$6.1 .1 \quad$ Breve nota biográfica . . . . . . . . . . . . . . . 72

6.2 Polifonia . . . . . . . . . . . . . . . . . . . . 73

6.2 .1 Polifonia enquanto diferenciação . . . . . . . . . . . . . . . 75

$6.2 .2 \quad$ Semantificação da Técnica Instrumental $\ldots$. . . . . . . . . . . . 83

6.3 Forma $\ldots \ldots \ldots \ldots \ldots \ldots$

$6.3 .1 \quad$ Inserção de Air em Opening of the Mouth . . . . . . . . . . . . 85

6.3 .2 Modelo Formal da Respiração . . . . . . . . . . . . . . . . . . 86 
6.3 .3 Seções . . . . . . . . . . . . . . . . . . . . . . . 98

6.4 A Corporalidade e o Som . . . . . . . . . . . . . . . . . . . . . . 105

6.5 Considerações finais . . . . . . . . . . . . . . . . . . . . . 110

\begin{tabular}{ll}
\hline III Conclusão & 111
\end{tabular}

\begin{tabular}{lll}
\hline 7 & Conclusão & 112
\end{tabular}

\begin{tabular}{ll}
\hline Referências Bibliográficas & 115
\end{tabular}

\begin{tabular}{ll}
\hline Referências Bibliográficas & 115
\end{tabular} 


\section{Lista de Figuras}

$3.1 \quad$ Sonata D.960 de Franz Schubert. . . . . . . . . . . . . . . . . . . 29

3.2 Segundo Quarteto de Cordas de Lachenmann: diferenciação dos componentes do gesto físico na notação musical $\ldots$. . . . . . . . . . . 33

$5.1 \quad$ Sonata K.120 de Domenico Scarlatti (edição de John Sankey) … 51

5.2 Trecho da Sonata K.54 (edição de Alessandro Longo) … . . . . . . . 52

5.3 Trecho inicial da Sonata K.54 de D. Scarlatti (edição de John Sankey)] 52

5.4 Compassos 5 e 6 da Sonata K.54 (edição de John Sankey) … . . . . 52

5.5 trecho do movimento Chopin de Carnaval op.9 de Robert Schumann . 54

5.6 trecho do Noturno op.9 $\mathrm{N}^{\mathrm{O} 2} 2$ de Chopin. Note o dedilhado 4-5-5-4-5-4. 54

5.7 Nota em jornal atribuída a Chopin. Ver nota de rodapé|5] . . . . . . 55

5.8 Sonata $\mathrm{N}^{\circ} 1$ Op.11 de Robert Schumann . . . . . . . . . . . . 56

5.9 Início de Alkan-Paganini (1997) de Michael Finnissy . . . . . . . . 57

5.10 Início da segunda parte de Alkan-Paganini (1997) de Michael Finnissy 57

5.11 Variações op.27 Movimento II de Anton Webern . . . . . . . . . . . 64

5.12 Alturas fixadas em registros $\ldots \ldots \ldots \ldots \ldots$

5.13 eixo de simetria $\leftarrow\left[l^{\prime}{ }^{\prime}\right] ;$ extremos agudo e grave $\leftarrow\left[\right.$ si, sol $\left.\left.^{\prime \prime \prime}\right]\right] .65$

5.14 Esquema geral das manipulações da série original $\ldots \ldots \ldots$. . . . 66

5.15 Gesto-chave da obra. . . . . . . . . . . . . . . . . 67

5.16 Gestos iniciais. . . . . . . . . . . . . . . . 68

5.17 Cruzamento brusco de mãos. . . . . . . . . . . . . . . . . . 69 
6.1 Chemins IV, baseado na Sequenze VII, para oboé e 11 cordas, de Luciano Berio . . . . . . . . . . . . . . . . . 78

6.2 Trecho de metallic dust para clarineta baixo solo de Aaron Cassidy. . . 84

6.3 Representação do espectrograma (preto) e da amplitude de Air (vermelho), duração total da peça. . . . . . . . . . . . . . . . . . . . . . . . . 88

6.4 Compassos 1 a 14 - com marcações para as cordas IV (azul), III (amarelo), II (vermelho) e I (verde). . . . . . . . . . . . . . . . . . . . 89

6.5 Compassos 20 a $30 . \ldots \ldots \ldots$

6.6 Compassos 31 a $44 . \ldots \ldots \ldots$. . . . . . . . . . . . . . . . 90

6.7 Compassos 46 a $54 . \ldots \ldots \ldots$. . . . . . . . . . . . . . . . . . . 91

6.8 Compassos $59-73$.

6.9 Compassos 74 a $81 . \ldots \ldots \ldots \ldots$. . . . . . . . . . . . . . . . 92

6.10 Compassos 85 a $96 . \ldots \ldots \ldots$

6.11 Compasso 19 de Air . . . . . . . . . . . . . . . . . 95

6.12 Compassos 3 e 4 de Air . . . . . . . . . . . . . . . . . . . . . 95

6.13 Símbolos referentes à pressão do arco . . . . . . . . . . . . . . . . . . . 97

6.14 Esquema geral de tamanho de frases de parte da primeira seção: dinâmicas, pressão e ponto de contado do arco inspirado na respiração; com inspirações e expirações. . . . . . . . . . . . . . . . . . . . . . . . . 100

6.15 Modelo de Respiração, com inspirações e expirações. . . . . . . . . . . 102

6.16 Figura de arpejo na segunda seção. . . . . . . . . . . . . . . . . . . . . 103

6.17 Compasso $60 . \ldots \ldots \ldots \ldots$

6.18 Compassos 78 a 81 de Air . . . . . . . . . . . . . . . . . 104

6.19 Espectrograma e fragmentos correspondentes da partitura, compassos 77 e 78. . . . . . . . . . . . . . . . . . . 107

6.20 Compasso 22 


\section{Lista de Tabelas}

$5.1 \quad$ Intervalos das Variações Op.27 de Webern . . . . . . . . . . . . . . . 62

5.2 Trajetórias da série original e séries derivadas. . . . . . . . . . . . 63

$6.1 \quad$ Estrutura geral de Engfürung II, último movimento de Opening of the Mouth. Note a crescente duração das seções referentes à obra Air. . . . 82

6.2 Durações de seções nas peças solistas $\ldots \ldots \ldots$. . . . . . . . . . . . 86

6.3 Posição do arco na corda . . . . . . . . . . . . . . . . . . . . . . 96 


\section{Capítulo 1}

\section{Introdução}

O objetivo do presente trabalho será o desenvolvimento de um estudo sobre o gesto musical e sobre a corporalidade na composição musical. Contudo não se trata de uma tentativa de elaborar uma teoria geral do gesto ou da corporalidade na música; tal empreitada seria por demais ambiciosa para o escopo dessa pesquisa. Em outras palavras, tentaremos contextualizar histórica e musicalmente, expor e contribuir teoricamente para as questões relacionadas à corporalidade e ao gesto. Alguns trabalhos teóricos já abordaram o tema através de perspectivas e tendências diferentes; tais tendências de investigação divergem em maior ou menor grau de modelos mais estreitos da musicologia e podem ser mais que suficientes para abordar alguns aspectos de certo repertório por um viés mais tradicional; porém, assim que abandonamos esse terreno mais documentado, nos deparamos com a necessidade de adotar novos modelos teóricos. Também analisamos com mais proximidade certos casos que evidenciam pontos que queremos destacar através de análises musicais, que não se limitam aos períodos mais recentes da História da Música, mas que tentam apontar indícios e casos particulares tanto do repertório tradicional quanto do contemporâneo, que apresentam de maneira mais explícita os pontos que desejamos abordar em nossa pesquisa.

As investigações teóricas que concernem o gesto e a corporalidade já possuem uma relativa bibliografia. Uma vez abandonado um certo repertório musical e teórico mais tradicional, as possibilidades estéticas e teóricas são ilimitadas, o que acaba por gerar 
um grande número de abordagens por vezes incompatíveis. Basta observarmos como os compositores Trevor Wishart e Brian Ferneyhough — da mesma geração e do mesmo país - fazem uso da noção de "gesto musical" de modo bem distintos.

Não pretendemos nos ater exclusivamente a uma explanação teórica, porém o que mais nos interessa aqui é justamente explorar as relações entre a música e a teoria da corporalidade (parte I), assim como analisar alguns casos mais específicos de como certos tipos de articulações gestuais atuam em uma determinada situação musical (parte II). Essa divisão em duas partes reflete uma separação sistemática dos capítulos. Inicialmente trataremos a questão por um viés mais teórico, e finalmente incluímos dois capítulos mais orientados aos estudos de caso, ou seja, análises musicais .

Nossa abordagem tentou mostrar evidências da importância do gesto físico e da corporalidade na produção musical, especialmente nas últimas décadas. Pesquisamos as obras e os textos de alguns compositores importantes da contemporaneidade que tratam tanto musicalmente quanto teoricamente a questão do gesto na música, como é o caso de Helmut Lachenmann, Brian Ferneyhough, Klaus K. Hübler, Richard Barrett, Frank Cox, Aaron Cassidy. Além dos compositores também achamos interessante colocar o ponto de vista do intérprete que trabalha efetivamente com esse repertório e que lida com a questão do gesto de uma maneira prática, como é o caso de Mary Oliver e Mieko Kanno, que deixaram também referências teóricas de suma importância para a relação da corporalidade com a notação e a interpretação musical.

Além de pesquisarmos sobre o gesto na música contemporânea, também achamos importante ressaltar que a corporalidade está presente na música desde os seus primórdios, mesmo que de uma forma mais ou menos explícita, como veremos com os compositores citados no capítulo 5 tais quais Domenico Scarlatti, Frédéric Chopin, Robert Schumann e, de um modo mais aprofundado, Anton Webern, que pertence à primeira metade do século XX, portanto um período de transição para a contemporaneidade.

Alguns problemas não são endereçados nesse trabalho. Não nos aprofundaremos nas questões ligadas à Filosofia da Mente abordadas no capítulo 4 , pois apesar de 
ser um tema muito importante, nos distanciaria demasiadamente do foco principal da pesquisa, que está relacionada à produção musical tradicional e contemporânea. Os apontamentos referentes ao problema mente-corpo estão colocados apenas para indicar uma hierarquização entre os componentes que constituem o sistema musical.

O plano inicial para o presente estudo abarcava a questão da corporalidade e do gesto físico enquanto apenas um aspecto do que entendemos ser um conjunto de novas e interessantes preocupações composicionais que surgiram na segunda metade do século XX e século XXI. Após alguns meses de trabalho percebemos que a pesquisa foi se concentrando nesse aspecto, que realmente se mostrou o campo no qual poderíamos contribuir da melhor forma para uma elaboração teórica.

No capítulo 2 trataremos do significado da noção de gesto e seu papel enquanto unidade morfológica, bem como outras noções relevantes como figura, textura e movimento. Pontuamos no primeiro capítulo a diferença entre gesto e movimento, que são usualmente tomados como sinônimos, mas que em nossa pesquisa serão mais claramente definidos e contextualizados no âmbito musical. Também discorremos sobre a questão da diferenciação entre os componentes acústicos, físicos e corporais do gesto musical.

No capítulo 4 abordaremos a questão da relação entre corporalidade e notação musical, em especial a notação prescritiva e a quebra de uma hierarquização instaurada na música mais tradicional entre parâmetros "primários" e "secundários". Inicialmente definimos os conceitos de notação descritiva, mais utilizada na música tradicional, onde se tenta descrever o resultado sonoro, e prescritiva, que é a notação que indica as ações necessárias para se obter um resultado, mais associada à música contemporânea e à notação de tablatura.

Na segunda parte do estudo continuamos a desenvolver o tema da corporalidade, porém a partir de casos concretos, ou seja, a partir de análises musicais, que não necessariamente tiveram o mesmo enfoque que um método mais tradicional centrado nas alturas. Em lugar disso, estivemos atentos para a relação entre o gesto físico como um novo parâmetro a ser levado em consideração na criação, interpretação e conse- 
quentemente na teoria musical. É nesta segunda parte que a questão da corporalidade finalmente é revelada como um novo componente a ser somado a todos outros parâmetros, e que é de igual importância na composição musical.

Ainda nessa segunda parte, no capítulo 5, analisaremos certos casos que pertencem ao repertório dos instrumentos de teclado, mais especificamente do cravo e do piano. Na seção 5.1 veremos, a partir de estudos de John Sankey, um importante cravista e musicólogo, como Scarlatti lançava mão da corporalidade como elemento integrante do discurso musical. Na seção 5.2 veremos certas características idiossincráticas do compositor Frédéric Chopin que sugerem uma forte inspiração de elementos de corporalidade em sua obra.

Reservamos um maior espaço para abordar o compositor Anton Webern, na seção 5.4 . Apesar de ser um compositor que quase sistematicamente é ligado a um tipo de construção puramente abstrata do material musical, tentamos aqui investigar a importância fundamental que a corporalidade possui na articulação musical de suas Variações op.27.

No capítulo final abordamos a obra Air de Richard Barrett, um dos compositores da segunda metade dos séculos XX e XXI que mais radicalmente desenvolveu uma linguagem pessoal ligada aos aspectos abordados no nosso estudo, dando uma grande importância para a corporalidade. A obra para violino solo de Barrett foi escolhida porque nela estão contidos praticamente todos os assuntos tratados no decorrer do trabalho: em Air podemos apontar a utilização de uma notação prescritiva e descritiva combinadas; utilização de parâmetros ligados à corporalidade de igual importância em relação aos parâmetros mais abstratos da notação; presença de polifonia paramétrica que abarca aspectos corporais e relação com questões de "poliobra". Finalmente tratamos da relação muito próxima da corporalidade com o timbre na seção 6.4, onde tentamos evidenciar forte ligação entre toda a articulação dos movimentos físicos presentes na obra musical com um elaborado sistema de timbres.

Neste trabalho tentamos realizar uma pesquisa sistemática em torno do gesto, da corporalidade, da fisicalidade e das consequências desses parâmetros na composição, 
interpretação, notação e análise musicais. Além de fornecermos um escopo teórico que busca elucidar e atualizar quanto à importância da corporalidade, também tentamos oferecer um respaldo mais concreto referente à prática musical, buscando a reflexão não só de teóricos e compositores, mas também de intérpretes que nos auxiliaram na pesquisa enviesada para o campo da análise musical. 


\section{Parte I}

\section{Gesto e Escritura}




\section{Capítulo 2}

\section{Gesto e Escuta}

Outra maneira de abordar uma coisa é considerá-la inominável

Ponge

A palavra gesto é muito comum na linguagem utilizada pelos músicos. Porém uma definição clara do seu significado pode não ser uma tarefa tão simples quanto pode parecer à primeira vista. O que realmente significa esta palavra? Entendemos que a resposta desta questão está no uso dessa palavra no contexto dos músicos, compositores, intérpretes e mesmo teóricos. Para certos termos a busca de uma definição verbal pode ser um pouco desconcertante ou mesmo criar mais problemas do que no início. Podemos imaginar outras palavras que também desafiam nossa tendência natural de se procurar um objeto que corresponda ao termo através de uma definição ostensiva: palavras como consciência, significado, dois, espaço ou comprimento. Wittgenstein acreditava que estaria aqui uma das grandes fontes de perplexidade filosófica: "um substantivo nos faz procurar por algo que corresponda a ele" (Wittgenstein 1985, p.1).

Tendo isso em mente e considerando que uma definição verbal pode nos trazer poucos benefícios - já que vai nos levar de uma expressão verbal para outra, ou pode nos levar para um terreno metafísico de onde seria difícil escapar posteriormente - , podemos tentar uma abordagem que almeje captar o significado a partir do uso do termo: de que forma essa palavra é utilizada no contexto da música? Nesse capítulo tentaremos 
deixar claro o significado que queremos dar ao termo gesto.

\subsection{Movimento}

Gesto é uma palavra usada em muitas disciplinas, como psicologia, linguística, antropologia, estética e musicologia; pode estar ligado a muitas conotações diferentes, algumas mais gritantes, outras mais sutis entre si. Dentro dessa diversidade semântica cada significado guarda, cada qual a sua maneira, uma ligação com um aspecto fundamental, que é o movimento do corpo humano. O movimento das mãos, do corpo, do aparato vocal etc.

Tais conotações podem possuir tanto uma função semântica quanto puramente expressiva. Uma explicação direta de gesto poderia ser dada como simplesmente um movimento de uma parte do corpo humano. No contexto da performance musical, gestos são movimentos feitos por um intérprete para controlar um instrumento musical. No contexto da escuta musical, gestos são movimentos que acompanham ou expressam a atividade da escuta, como a ação de bater palmas de acordo com o andamento de uma música. Esta definição tem como foco principal o movimento físico e dá uma importância menor à expressão e à intenção.

\subsection{Gesto e movimento não são sinônimos}

O gesto guarda uma relação com o movimento, mesmo que metafórica. Porém nem todo movimento pode ser considerado um gesto: para um movimento ser considerado gesto ele deve se tornar significativo para um sujeito que imprima uma intencionalidade e interpretação a esse gesto. Claramente isso introduz um aspecto subjetivo bem como um aspecto de dependência de contexto. Um mesmo observador em diferentes contextos pode ter interpretações diferentes, ou em um mesmo contexto dois observadores podem interpretar o mesmo gesto de maneiras totalmente diversas. Em suma: um movimento é considerado gesto quando está inserido em um contexto onde haja uma determinada intencionalidade passível de interpretação.

Acreditamos que é de extrema importância que as considerações sobre o gesto não se 
restrinjam apenas ao seu aspecto mais facilmente mensurável (o movimento) pois esta simplificação pode nos limitar e prejudicar o entendimento de que existe uma cadeia de aspectos relacionadas à comunicação e interpretação em conexão ao movimento físico. Assim, podemos considerar que movimentos corporais controlam instrumentos para gerar ondas sonoras no ar; esses movimentos são em contrapartida transmitidos aos ouvintes, recebidos pelo aparelho auditivo, passa pelo sistema nervoso, pelo cérebro, movimenta e afeta o corpo do ouvinte. Toda essa cadeia de acontecimentos decorrente de um movimento tem consequências complexas do ponto de vista dos estados mentais que o ouvinte é levado a ter. Essa rede de eventos constitui um objeto de pesquisa muito mais complexo, que envolve a inter-relação entre distintas áreas da percepção, indo além da simples averiguação de um movimento.

\subsection{Gesto físico e sonoro}

Temos aqui uma interessante distinção entre dois aspectos de um gesto:

- o aspecto físico, o movimento enquanto tal, simplesmente;

- o aspecto sonoro, o resultado acústico desse movimento físicd 1 .

Podemos perceber que o movimento é uma parte essencial do gesto, porém a noção de gesto não é equivalente à noção de movimento. Para a definição de gesto precisamos de um componente subjetivo, mental, racional, consciente, dependente de um contexto, com intencionalidade e com um sentimento qualitativo em relação a um fenômeno físico.

Além da ação e da intencionalidade podemos acrescentar o componente da incorporação, ou seja, da imagem mental que o ouvinte faz de um gesto. Segundo Delalande (1988) o que define um gesto musical é a intersecção das ações observáveis e as imagens mentais. Ele também sugere que há uma certa tipologia dos gestos, podendo se tratar de configurações puramente simbólicas em um caso extremo ou puramente funcionais em outro. Ele utiliza alguns termos que nos ajudam a analisar os diversos

\footnotetext{
${ }^{1}$ A propagação do som também pode ser considerada um fenômeno mecânico; em nosso caso, entretanto, utilizamos a palavra "físico" para indicar o movimento corporal do músico.
} 
aspectos do gesto: gesto efetivo, gesto acompanhante e gesto figurativo. O gesto efetivo, ainda segundo Delalande, por exemplo, seria o que pode ser chamado de um gesto que produz som efetivamente; o gesto acompanhante é o movimento físico que está por trás do gesto efetivo; já o gesto figurativd ${ }^{2}$ corresponderia à imagem mental que não é provocada por nenhum tipo de movimento físico correspondente e que ocorra de fato, mas que é sugerida pelo som.

\subsection{Movimento e Significado}

A voz é talvez o lugar da mais radical de todas as divisões subjetivas - a divisão entre significado e materialidade.

KAJA Silverman

Uma visão mais atenta do termo gesto revela o potencial para promover um acesso a questões centrais de processos de percepção e de ação, bem como de processos de interações entre mente e ambiente. Uma das vantagens de se usar o termo gesto é que ele transcende o impasse da dicotomia cartesiana (Descartes 2005) da mente e do corpo, pois o gesto musical vai além do puro movimento físico e depende fundamentalmente da intencionalidade do ouvinte diante desse fenômeno físico. De um lado temos um fato ontologicamente objetivo de um movimento corporal que pode ser medido e que não depende de uma consciência para existir, ou seja, um fenômeno de terceira pessoa. Por outro lado temos um fato que consiste em um estado mental ontologicamente subjetivo porém episteticamente objetivo da percepção musical, um fenômeno de primeira pessoa.

\subsection{Unidade Morfológica}

O estímulo, como o conhecemos, é de infinita ambiguidade, e ambiguidade enquanto tal... não pode ser vista.

ERNST GOMBRICH

Dentre as possíveis maneiras de se abordar o gesto, também podemos entendê-lo

2 A expressão "gesto figurativo" utilizado por Delalande não se relaciona com o termo "figura" que usaremos mais adiante na seção 2.7 
como uma unidade portadora de conteúdo musicalmente significativo. Partamos do princípio de que um evento musical pode ser decomposto até chegarmos aos seus elementos mínimos, muito embora o que acarreta a experiência musical não é cada um desses elementos mínimos isolados, mas a propriedade que surge da inter-relação entre eles, em conjunto. Esta propriedade que surge da relação dos elementos mínimos é o que constitui uma determinada configuração portadora de conteúdo musicalmente significativo.

Vamos utilizar uma pequena comparação para ilustrar essa relação entre os elementos simples e uma propriedade que não está presente em nenhum lugar desse sistema, mas é uma propriedade que emana das inter-relações dos elementos em funcionamento. Pensemos na propriedade da liquidez da água: assim como a liquidez é uma propriedade da água, também é verdade que a água é composta de moléculas de $\mathrm{H}_{2} \mathrm{O}$. A propriedade da liquidez emana das interações entre essas moléculas em uma dada temperatura. São dois níveis diferentes de se ver o mesmo evento. Não somente uma mudança no nível mais baixo (a molécula $\mathrm{H}_{2} \mathrm{O}$ ) pode acarretar uma mudança no nível mais alto (a liquidez), como também mudanças no nível mais elevado podem ocasionar consequências no nível mais baixo. Se considerarmos um objeto como algo simples isso significa que este não é composto de outros elementos, ou seja, não é complexo. Dizer que um objeto é complexo significa que ele é formado por partes que se inter-relacionam de modo particular, o que constitui um todo. Porém, apontar para um objeto e dizer se é simples ou complexo é algo relativo, que depende do que se quer dizer por complexo e em qual nível de descrição a intenção da pergunta se encontra. Embora definições possam variar, podemos entender que, dado um contexto, o que queremos dizer quando falamos de uma formação de elementos é que os elementos individuais são semanticamente menos importantes quando isolados do contexto de uma dada formação musical, ou conforme o caso até mesmo irrelevantes. O desenvolvimento do termo gesto representa uma propriedade da consciência e da realidade da percepção musical, que por sua vez tenta agrupar e organizar os eventos musicais. 
A partir de dois excertos dos compositores Stockhausen e Andriessen podemos exemplificar com mais clareza o que tentamos demonstrar. Primeiramente com o conceito de grupos de Stockhausen, que relaciona a ideia de um complexo de sons que juntos formam um gesto, uma formação, ou um "grupo". Stockhausen demarcou a unidade morfológica com seu conceito de grupos, que são mais importantes semanticamente do que cada um dos elementos que constituem esse grupo.

Quando não podemos mais contar as notas individuais em um grupo, elas ultrapassam o grupo [...] quando não podemos mais contar os elementos, então isso depende da velocidade: naturalmente, quando o passo é rápido demais não conseguimos mais contá-los, e 13 notas podem parecer um só gesto, não se tem vontade de contá-las. Ou há eventos demais acontecendo de uma vez, como em um enxame de abelhas; quando o enxame é percebido como uma formação, tornase uma entidade única. Se vemos uma árvore, não contamos as folhas, mas ainda assim somos capazes de distinguir um pinheiro de uma faia. É um efeito dos elementos, mas há algo a mais, o formato, a forma como um todo, que caracteriza a massa. (Stockhausen 2009)

A noção de grupo é muito cara a Stockhausen, e foi o que o permitiu efetivamente avançar para além dos impasses da primeira fase do serialismo integral. Ao nosso ver a noção de grupo foi altamente frutífera para Stockhausen justamente porque lhe permitiu uma via de acesso à organização de estruturas mais próximas à percepção musical, que podem se comportar enquanto gestos, e o compositor tem acesso, dessa maneira, aos componentes internos do gesto. Apesar de constituir uma abordagem completamente diferente da apresentada por outros compositores - dentre esses Ferneyhough, Delalande e Lachenmann, também investigados nesse trabalho —, a ideia mais ampla de grupo é muito pertinente para uma sensibilização por parte do compositor para o modo como percebemos a música, através de unidades morfológicas que não coincidem necessariamente com a noção de uma nota, representada por uma única altura e duração; porém uma noção de gesto, ou figura na nomenclatura utilizada por Ferneyhough (como veremos na seção 2.7) tem o potencial de ter acesso aos parâmetros constituintes 
daquilo que efetivamente percebemos como a unidade formadora de significado musical, com o potencial de construção que o serialismo trouxe à produção musical contemporânea.

O compositor Louis Andriessen também descreve a importância do gesto em sua prática musical:

Eu acredito que [eventos musicais] são muito físicos. Pelo menos no meu caso, se é bom, vem do movimento. Como Stravinsky disse, 'música não vem do pensamento, mas do movimento'. Um tipo de movimento musical. Eu penso que ambos [gestos físicos e gestos musicais] desempenham um papel importante. (Andriessen 2006, p. 543$)^{3}$

Podemos perceber alguns elementos relevantes para nossa investigação nestas duas declarações. Stockhausen afirma algo em linhas análogas ao que tentamos expor anteriormente sobre a característica de nossa percepção de agrupar eventos em conglomerados mais ou menos complexos, e nesse processo tendemos a abstrair a percepção desses elementos mais simples em favor de uma gestalt, uma formação, um grupo, ou o que poderíamos chamar de um gesto.

Já o compositor Andriessen expressa uma crença na ligação intrínseca entre os eventos musicais com o movimento e a fisicalidade, ao nosso ver tanto aquela fisicalidade que causou tais eventos quanto aquela que eles despertam na mente do ouvinte. Gesto refere-se a um movimento; e, implicitamente, a uma duração deste movimento e desta ação. Andriessen também esboça uma separação conceitual entre o gesto físico em si e o gesto musical. O gesto musical, do nosso ponto de vista, também pode ser entendido como algo composto do evento acústico e da ação sob a interpretação e intencionalidade da percepção de um sujeito.

Podemos encontrar ainda um terceiro compositor, Brian Ferneyhough, que baseou grande parte de sua reflexão teórica em torno das ideias de gesto, figura e textura.

\footnotetext{
3"I believe that musical events are very physical. At leaset in my case, if it's good, it comes from movement. As Stravinsky said, 'Music comes not from thought, but from movement.' A sort of musical movement. I think that for me they both [physical and musical gestures] play a role"
} 
Porém antes devemos tentar deixar claro até que ponto há uma intersecção entre o que chamamos anteriormente de gesto e o que Ferneyhough procura classificar como gesto e figura. Essa distinção adicional entre "figura" e "gesto" é muito cara a Ferneyhough e devemos analisá-la melhor antes de seguir.

\subsection{Figura e Gesto}

Para evitar futuras confusões utilizaremos as palavras gesto e figura entre aspas quando elas corresponderem precisamente ao significado atribuído por Ferneyhough a esses termos. Há um outro fator a ser considerado: essas duas categorias (gesto e figura) não são autoexcludentes nem incompatíveis; um gesto pode revelar seu aspecto figural ou seu aspecto gestual de acordo com o processo no qual ele está inserido e com as referências as quais ele remete. Como Ferneyhough coloca, deve-se fazer uma distinção entre "o gesto enquanto tal", uma presença objetiva do gesto ligada diretamente ao material e o aspecto figural do geste $4^{4}$ Nesse caso Ferneyhough está se remetendo ao "gesto" que se refere a algo, a um estilo, a uma outra situação, e que, como um todo, significa algo. Isso não é, de modo algum, o que definimos como gesto nas seções anteriores. Percebemos o "gesto" de Ferneyhough como uma propriedade, um subconjunto por assim dizer, do gesto. Nossa concepção de um gesto com potenciais (des-)(re-)construtivistas e está ligado diretamente ao conceito de "figura".

Isso pode ser um ponto que pode criar confusão para os leitores desse trabalho, porém gostaríamos de lembrar que o próprio Ferneyhough apontou que o que ele chama de "figura" ou a "figuralidade do gesto" é, de fato, para ele também, uma subcategoria do gesto.

Uma das coisas que tento fazer é distinguir a diferença entre o gesto enquanto tal, que em si é uma presença objetiva e vinculada ao material — podemos examinar suas delineações, podemos apreciá-lo como um 'vocábulo' em qualquer nível (fato que é a razão que para mim o estilo geral não é de muita importância - pode-se

\footnotetext{
${ }^{4}$ Citação completa nesta página.
} 
escrever em quintas paralelas ou qualquer outro estilo: isso não é importante), e o aspecto figural de um gesto ('figuralidade' sendo ela mesma uma subcategoria do gesto). O que distingue a maneira figural de construção ou observação de um gesto da parte 'gestual' do gesto é que tenta-se entender a totalidade do gesto através das possíveis desconstruções em tendências paramétricas’

Com a citação acima esperamos que o que Ferneyhough caracteriza como "figura" esteja clara. A "figuralidade do gesto", para nosso estudo, constitui o grande potencial de estruturalidade do gesto. Na verdade essa distinção pode ser melhor compreendida em um argumento musical mais estruturado, do que na análise de um gesto isolado.

[...] tenta-se construir gestos em que as qualidades paramétricas das quais são compostos são lançadas no mundo da música para o futuro, para o potencial futuro da música, no momento em que o gesto se apresenta. (Ferneyhough 1995, p.285)

O conceito de parâmetro é largamente entendido e utilizado na composição musical desde o início da década de 1950. Tratou-se de uma ferramenta por parte do compositor, para poder trabalhar mais diretamente com os diferentes aspectos do material musical. Mas aqui podemos perceber algo interessante, se a princípio o termo parâmetro se referia exclusivamente às características mais facilmente codificadas em notação musical e, por assim dizer, "racionalizáveis", primeiramente foi ampliada para abarcar o conceito de grupo (em Stockhausen, como vimos anteriormente); porém, em um

\footnotetext{
5"One of things I'm trying to do is to distinguish between the gesture as such, which in itself is an objective, material-bound presence - we can examine its delineations, we can appreciate it as a total 'vocable' on whatever level (which is why overall style is of no great importance to me - one can write in perfect 5ths or whatever: that's not the question), and the figural aspect of a gesture ('figurality' being itself a subcategory of gesture). The thing which distinguishes the figural way of constructing or observing a gesture from the 'gestural' part of the gesture is that one is attempting to realize the totality of the gesture in terms of its possible deconstruction into parametric tendencies."

6"That is, no longer does one attempt to create a gesture via the automatic coming together of abstract parametric units or quantities, nor does one try to build a gesture as an affective quality, and place there totalities against one another. One attempts to so construct gestures that the parametric qualities of which they are composed are released into the world of the music, as it were, into the future, the future potential of the music, at the moment in which the gesture presents itself."
} 
segundo momento um passo adicional foi tomado por compositores como Brian Ferneyhough. Este compositor considera um parâmetro toda e qualquer característica de um objeto musical que possa ser discernível através da percepção. Isso acarreta que certas características anteriormente desprezadas do material musical agora podem ser incorporadas no trabalho de composição e tratadas enquanto parâmetros, assim como as alturas e as dinâmicas. Um gesto, ou "figura", desse modo, pode ser entendido como um complexo formado por trajetórias de parâmetros; e tais parâmetros podem extrapolar os chamados parâmetros "primários" 7 e abarcar tudo o que seja relevante para o discurso, incluindo-se aí as ações físicas, a corporalidade e vários aspectos tratados nessa pesquisa.

Então no momento em que o gesto é realmente dissolvido no futuro, certos elementos paramétricos, os quais devem em suas próprias razões ter sido embutidas nesse gesto (e portanto não são mais quanta isolados [...]), são liberados de modo a poder juntar variantes de muitas maneiras, ou coincidir para produzir novas unidades gestuais. (Ferneyhough 1995, p.285)

Ferneyhough prossegue colocando que para ele a situação ideal não está na construção de material a partir de "gestos abstratos" ou de um suposto "pensamento paramétrico para gerar gestos", porém algo realmente caro a Ferneyhough é o "emprego livre e turbulento", assim como "gestualmente justificado" que constituem o "centro de toda a preocupação composicional’’9

Aqui podemos extrair as principais ideias presentes no texto de Ferneyhough, que

7 Sobre a diferenciação entre parâmetros "primários" e "secundários" atribuímos por Pierre Boulez, ver a seção 4.2

8"So at the moment in which the gesture actually dissolves into the future, certain parametric elements, which owe their original raison d'être to having been embedded in this gesture (and therefore are no longer isolated quanta, floating, 'quarks' or whatever), are released in order to be able to conflate in different ways, or coincide to produce new gestural units. So for me, the ideal situation is one in which neither the abstract gesture in itself, nor the use of parametric thinking to generate gestures, but the gestually justified, free-ranging employment of parametric information is the center of all compositional concern."

9 "So for me, the ideal situation is one in which neither the abstract gesture in itself, nor the use of parametric thinking to generate gestures, but the gesturally justified, free-ranging employment of parametric information is the center of all compositional concern." (1995, p.285) 
elucidam nossa investigação a cerca do gesto:

- maneira figural de construção;

- figuralidade como uma subcategoria do gesto;

- a parte gestual do gesto;

- desconstrução do gesto em tendências paramétricas.

As ideias de parâmetro e construção são muito importantes em nossa pesquisa, mas não menos fundamental é também a distinção entre sua concepção de "figura" e outras duas práticas possíveis:

1. a composição automática de unidades paramétricas abstratas;

2. a construção de um gesto enquanto uma qualidade afetiva.

Obviamente trata-se de uma simplificação grosseira, mas que serve de ilustração ao que o autor tenta caracterizar como processo "figural" de composição, que não corresponde às enumerações logo acima. Ferneyhough propõe um novo modo de lidar com os processos construtivos de formações musicais, sensível a contextos e tendências, mas que não abrem mão de um processo de organização.

O compositor e violoncelista estadunidense Frank Cox também relata, através de uma experiência própria, algo que corresponde ao impasse descrito no item 1:

Iniciei minha descida ao Abgrund $[10$ das possibilidades inesgotáveis da organização e composição das mais sutis distinções entre os fatores que contribuem para a produção sonora em um instrumento, utilizando-me de técnicas seriais. Durante a fascinação inicial com esses recursos, confiei em minha intuição para alcançar configurações significativas empregando procedimentos seriais para gerar e modelar materiais previamente desconhecidos. Entretanto vim a reconhecer várias armadilhas formalistas à espreita: apesar dos procedimentos seriais poderem gerar uma vasta gama de sons e texturas impressionantes, assim como suas transformações, eles não podem em si mesmos assegurar sua significância na experiência

10 'Abismo'. 
[musical], nem localmente nem no que diz respeito ao drama de sua composição temporal. A intuição pode ser aplicada à geração de estruturas e processos formalistas autônomos, porém uma vez em movimento pode-se tanto tentar magicamente abastecê-los com significância [...], ou afirmar-se em detrimento deles (quebrando assim o círculo mágico da autonomia auto-consistênte, uma premissa central do formalismo radical). Serialismo formalista é indiferente em relação às qualidades dos materiais; seu próprio círculo [de atuação] é delimitado pelos aspectos quantificáveis de qualquer material. Mesmo sendo extremamente útil na produção de componentes notáveis de material sônico, [...] raramente resultam em estruturas integralmente artificiais sendo experimentalmente ricas durante um período mais prolongado de tempo, como aquelas alcançados pelo Alto Modernismo, que tinha como premissa transformação extrema e alienação de materiais, e cuja qualidade linguística foi herdada da música tonal/modal. (Cox 2005) ${ }^{11}$

Tal experiência composicional, segundo o próprio Frank Cox, falhou em mediar de maneira mais produtiva:

- a intuição "intrinsecamente fundamentada no processo composição";

• "um mundo de experiência único com transformações únicas a esse mundo";

- uma geração flexível e consistente de material. (Cox 2005)

O que seria o "aspecto figural do gesto" além da desconstrução do gesto expondo seus constituintes paramétricos? Esses componentes estão, assim, acessíveis ao compositor,

11"I began a descent into the Abgrund of the inexhaustible possibilities of independently organizing and layering by serial means minute notatable distinctions among all factors contributing to sound production on an instrument. During the initial entrancement with these resources, I trusted my intuition to achieve meaningful configurations by employing serial procedures to generate and shape previously unknown musical materials. However, I came to recognize several lurking formalist traps: although serial procedures could generate a wide range of striking sounds and textures as well as their transformations, they could not of themselves either ensure their experiential significance, either locally or in terms of the drama of their temporal shaping. Intuition could be applied to the generation of autonomous formalist structures and processes, but once these were set in motion, it could either attempt to magically bestow them with significance (by asserting that these 'really' meant something else than what was in public evidence), or assert itself at their expense (thereby breaking the magic circle of autonomous self-consistency, a central premise of radical Formalism). Formalist serialism is indifferent with regard to materials' qualities; its proper sphere is limited to the quantifiable aspects of any materials. Although it is extremely useful in generating striking compounds of sonic material, its divesture of 'auratic' surplus from materials in the interests of structural combination has, despite its aims of 'overcoming' high-Modernism, rarely resulted in wholly artificial structures as experientially rich, over a sustained period, as those attained by high Modernism, which was premised on an extreme transformation and estrangement of materials whose language-quality was largely inherited from tonal/modal music." 
e representam "o potencial futuro da música no momento em que o gesto se apresenta ". O que é sublinhado aqui é que o gesto pode ser encarado como um "objeto processual" (Ferneyhough 1995, p.414). Acreditamos que o que o compositor Frank Cox chamou de "serialismo formalista" esteja em estreito paralelo à crítica que Ferneyhough realiza aos "pós-serialistas" nos textos citados, em que a existência de correntes de informação paramétricas se desvincula de uma implementação concreta em um argumento musical.

Em ambos os casos (itens 1 e 2) Ferneyhough aponta o problema de se criarem blocos isolados e de se menosprezar o potencial processual da "figura". A "figura" pode ser entendida como um objeto manipulável que se projeta para o futuro enquanto gerador de forma. O "aspecto figural do gesto" possui uma capacidade variável de permitir que essas camadas sobrepostas de parâmetros sejam flexíveis para separações, extensões e recombinações em constelações posteriores. E nesse contexto não é preciso ater-se aos parâmetros mais convencionais por vezes chamados de parâmetros primários, representados pela altura, ritmo e dinâmica; mas qualquer variável que seja um componente significativamente claro dentro de uma formação, e que isso garanta espaço suficiente para desdobramentos em outras formações.

Ferneyhough utilizou diversas imagens para ilustrar o que ele quis dizer com objetos processuais e processos, assim como o aspecto "figural" do gesto. Ele recorre muitas vezes à ideia de linhas de forçc12 (que também poderiam ser chamada de 'vetores') que agem sobre gestos. Uma dessas imagens consiste na onda em movimento de colisão a uma rocha, uma forçą que pode ser percebida pela forma como a onda se manifesta após a colisãd13, Ou ainda como um "raio laser, você o distorce, amassa, quebra, fratura, torce, e através do grau de estrago que esse objeto agora apresenta, podemos começar a julgar o tipo e a qualidade da energia que lhe foi aplicada" (Ferneyhough et al. 2008).

\footnotetext{
12 Termo oriundo do filósofo Gilles Deleuze em 'Logique du sens', livro inspirado na obra do pintor Francis Bacon (Deleuze 2003).

13 “They seemed strange only because we couldn't actually see them / And we realized this only ar a point where they lapse / Like a wave breaking on a rock, giving up / Its shape in a gesture that expresses that shape" (AsHBERRY, J. 'Self-portrait in a convex mirror' apud. Ferneyhough 1995 p.34).
} 
$\mathrm{Na}$ verdade esses vetores - aqui preferimos esse termo, mas que está absolutamente relacionado às linhas de força — podem ser entendidos em várias dimensões, por exemplo o quão próximo ou distante se está desse gesto. Podemos estar muito próximos ou demasiadamente distantes, ou perdendo a ideia de sua gestalt, ou não percebendo suas potencialidades gerativas e de projeção em outras alocações temporais. Com a ideia de vetores criamos uma ponte entre materialidade e violência, coisas que são o que são, e coisas que tendem inerentemente à mudança imprevisível, tendo em vista a força aplicada. Seriam essas torções causadas por vetores aplicadas a um gesto "que nos revelaria a quantidade de partículas energéticas" por meio do atrito, da resistência, da oposição hostil que lhe é aplicada em um dado contexto. Essa "quantidade de partículas energéticas" talvez seja mais reveladora do que o objeto inicial por si só .

Novamente volto à idéia do raio de laser: você o aplica a um objeto, você entorta, tira uma lasca, trinca, torce, e através do grau de distorção que esse objeto agora apresenta nós podemos começar a julgar o tipo e a quantidade de energia que foi nele aplicada. Desta maneira criamos uma ponte entre "coisificação" e força aplicada, entre coisas que são concretamente o que elas são e coisas que tendem a mudar imprevisivelmente devido à força aplicada sobre elas. Eu geralmente chamo isso de torque: é a resistência que o processo de torção aplica ao objeto que nos diz o tipo e a quantidade de partículas de energia que estavam em jogo naquele momento. (Ferneyhough et al. 2008)

Algo importante a ser lembrado é que essa não é de fato uma classificação, mas representa antes de tudo um modo de observar e reconhecer a função de um gesto, segundo o próprio Ferneyhough "a utilidade para [o compositor] reside principalmente no encorajamento de cross-fadings de um modo a outro".

Um dos lados da questão sobre os usos do termo 'figura' em Ferneyhough é uma crítica não só ao encapsulamento dos parâmetros que constituem uma certa concepção de gesto mas também às práticas que se relacionam ao serialismo e ao pós-serialismo onde materiais são construídos pela intersecção de camadas produzidas separadamente. Como colocou Frank Cox na citação 2.6, o método mais radicalmente formalista do sera- 
lismo e pós-seralismo é "indiferente em relação às qualidades dos materiais; seu próprio círculo [de atuação] é delimitado pelos aspectos quantificáveis de qualquer material". O que Ferneyhough sugere em suas investigações é que tais diagramas de materiais "nasçam legitimados por meio da incorporação funcional em um contexto gestual concreto" $\left(1995\right.$, p.387) ${ }^{14}$

Ele concebeu seus objetos musicais manipuláveis como entidades instáveis e dinâmicas de:

1. um gesto delimitado e funcional, um evento musical com uma gestalt imediata, clara e gestual;

2. ao mesmo tempo exercendo um papel gerador de forma, estabelecendo trajetórias das características constituintes de sua forma.

O aspecto figural do gesto possui uma capacidade variável de permitir que essas camadas sobrepostas de parâmetros sejam flexíveis para separações, extensões e recombinações em formações posteriores.

\subsection{A relação entre textura, gesto e figura}

É preciso esclarecer que essa classificação entre figura, gesto e textura não é excludente; como aponta Ferneyhough, "a utilidade para [o compositor] reside principalmente no encorajamento de gradações de um modo a outro" (Ferneyhough 1995, p.414).

Nos textos Form-Figure-Style e Il tempo della Figura (1995), Ferneyhough reflete sobre questões relacionadas ao estilo, ao modo como produzimos e percebemos o gesto na tentativa de elucidar de alguma forma os elementos estruturais internos em jogo na

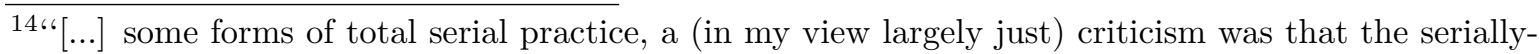
generated intersection of parametric strands produced a sound object which in no way clearly reflected the ordered nature of these same strands: the polyphony was generationally virtual whilst remaining perceptually latent. In my own recent pieces, I've tried to bypass this problem by allowing the individually manipulable parametric strata to begin like authenticated by means of functional embedding in a concrete gestural context. I invariable envisage a sonic event as fluctuating between two notional poles - that is, its immediate, identifiable, gestural gestalt, and its role as a launching pad for the subsequent establishment of independent linear trajectories of the gestalt's constituent characteristics." 
composição musical. Na verdade não classificar, mas evidenciar modos de observar um objeto musical, ou reconhecer uma certa função: a textura, o gesto e a figura.

Há em especial uma crítica realizada por Ferneyhough que concerne a utilização do "gesto" na composição musical. Ferneyhough denomina gesto como algo convencionalmente sedimentado em um domínio sintático exteror; que não pertença, pois, a uma história do trabalho do compositor, que não seja um "objeto processual": a consistente reutilização e modificação desses elementos no curso de várias obras da produção de um compositor, indiferentemente ao seu estilo ou conceito de material. O que estaria por sua vez ligado a uma ideia da formação de um "estilo", da construção de sua própria morfologia musical.

Ferneyhough atesta ter buscado uma solução para o que ele vê como um problema da composição contemporânea permitindo que tais diagramas de materiais, citando novamente, "nasçam legitimados por meio da incorporação funcional em um contexto gestual concreto" (1995,p.387). Aqui sim se apresenta o conceito de "figura", e que corresponde mais diretamente ao gesto com potencial de construção, desconstrução e reconstrução. Ferneyhough concebeu seus objetos musicais manipuláveis como entidades instáveis e dinâmicas de

- um gesto delimitado e funcional, um evento musical com "uma gestalt imediata, clara e gestual";

- ao mesmo tempo exercendo um papel gerador de forma, "estabelecendo trajetórias das características constituintes de sua forma". (p.387).

O aspecto figural do gesto (evento, objeto musical, frase) possui uma capacidade variável de permitir que essas camadas sobrepostas de parâmetros sejam flexíveis para "separações, extensões e recombinações em constelações posteriores". E neste contexto, continua Ferneyhough, não é preciso se ater aos "bons e velhos parâmetros [primários]" 15 , pois pode-se pensar qualquer coisa enquanto um parâmetro desde que "permita

\footnotetext{
${ }^{15}$ Sobre os parâmetros 'primários' e 'secundários', ver seção 4.2
} 
uma modulação por graus", e "seja um componente suficientemente claro de sua gestalt geradora para garantir sua percepção nos demais contextos"(Ferneyhough 1995).

$\mathrm{Na}$ nossa pesquisa esperamos levar em consideração o gesto como uma unidade morfológica de primeira grandeza, composto não só pelos parâmetros mais tradicionais das alturas durações; mas por todos os parâmetros musicalmente significantes em um dado contexto musical, o que pode incluir aspectos físicos e corporais, e as mais ou menos complexas inter-relações estre os parâmetros em jogo em um argumento musical. 


\section{Capítulo 3}

\section{Aspectos da Escuta Musical}

Uma teoria do corpo já é uma teoria da percepção MERLEAU-PonTy

Um dos motivos que levaram Lachenmann a radicalizar certos aspectos da notação e da composição musical no que se refere à corporalidade e à fisicalidade são algumas conclusões que ele entende serem universais na percepção da música. No caso de nossa pesquisa gostaríamos de destacar um ponto que consideramos crucial para a virada estética de Lachenmann: o atrito e a ambivalência entre dois aspectos da escuta músical; por um lado tradição e hábito, de outro fisicalidade e corporalidade. Lachenmann crê que tal atrito e ambivalência esconde uma hierarquização e uma repressão da fisicalidade por parte de nossa tradição musical. Tal fato impulsionou Lachenmann a adotar procedimentos radicais para expor tal ambivalência entre esses dois aspectos, o que resultou em interessantes resultados estéticos e sujeitos a uma discussão muito frutífera.

Segundo Lachenmann (2004,p.61) não existe nenhuma experiência musical onde os seguintes quatro aspectos fundamentais da escuta não estejam interconectados e se apresentem de forma imediata e intuitiva 1 :

\footnotetext{
1"Tonalität — Körperlichkeit — Struktur — Aura: Es gibt keine Musik, die im Zusammenwirken dieser vier Aspekte nicht von jedem Hörer unmittelbar und intuitiv verstanden würde. Nichts gibt es, was noch zu entschlüsseln wäre. Und dennoch: Die Auseinandersetzung mit den Bedin-
} 
- tonalidade e hábito;

- corporalidade e fisicalidade;

- estrutura;

- aura.

Para nosso estudo será interessante explorar a tensão entre os dois primeiros aspectos fundamentais: entre o hábito/tradição e o fenômeno acústico/corporal. Essa diferenciação nunca foi elaborada anteriormente a Lachenmann no campo da música instrumental. Lachenmann desenvolveu suas experiências composicionais através da estratégia de radicalizar a corporalidade na música, na tentativa de suprimir de nossa percepção o componente do hábito da experiência musical, a seu ver relacionado a um conceito de material burguês, tonal e do chamado bom som. A passagem abaixo pode revelar algo sobre a relação entre o bom som do aparato estético dominante estabelecido e a algo que o perturbe e exerça uma resistência em relação a ele.

De fato, um estudo das obras do período estilístico'clássico' do serialismo [integral], tais como Canto Sospeso ou Incontri de Luigi Nono, Structures ou Marteau de Boulez, Gruppen ou Kontra-Punkte de Stockhausen, revelam que o rigor constrangedor desta música não é somente derivada da consistência virtuosa com o qual as regras autoimpostas são aderidas - não menos porém de um conhecimento com o qual a música, mesmo com a ajuda de tais sistemas de regras - e em contato dialético com elas - constituem uma reação às estruturas sociais existentes e às regras comunicativas existentes do aparato estético burguês que eles criaram, e os oferece resistência - não só teórica mas real - colocando seu funcionamento normal fora de ação, de fato às vezes até o destruindo. Foi tal resistência ao estabelecido que constituiu a força de tal erupção estética revolucionária e considerou

gungen des Materials kann aus sich heraus niemals zu eindeutigen Interpretationen, geschweige denn zu eindeutigen äesthetischen oder kompositionstechnischen Schlußfolgerungen und Doktrinen führen.Denn jeder im Material wirkende Zusammenhang ist vieldeutig, steht selbst wiederum in Zusammenhängen, ist ein Konglomerat aus Zusammenhängen, bewußten, unbewußten, bedachten, unbedachten, rationalen, unrationalen — und der Komponist hat nicht weniger Schwierigkeiten, seine Musik zu verstehen, als jeder andere. Damit ist, so scheint es, dem Komponisten, der auf die hier vorgetragenen Reflexionen sich eingelassen hatte, abenso wie dem denkenden Hörer, alles wieder aus den Händen geglitten. Was immer der Komponist hat nicht greifbaren Ganzen. Wer weiß: Vielleicht kontrolliert das Ganze ihn, und der Komponist ist der Schwanz, der mit dem Hund wedelt." 
a beleza de tais obras em um tempo que o conceito tradicional de 'beleza' era vista com muita suspeita por esses compositores. (Lachenmann 2004, p.83-92) ${ }^{2}$

Lachenmann buscou um novo conceito de material que não só entrava resistiu às convenções tradicionais relacionadas à tonalidade, mas em relação à própria natureza dos sons e de seus modos de realização. Esse novo material exigiu uma diferenciação dos componentes internos do gesto, onde podemos perceber os aspectos da escuta, incluindo suas contradições e ambiguidades. Esse desacoplamento dos componentes e a radicalização do elemento corporal e acústico acarretaram uma escrita extremamente idiomática. As razões por trás desse novo material, do ponto de vista do próprio Lachenmann, estão muito próximas de apontar para uma concepção aparentemente oposta à produção do "período clássico do serialismo", onde as questões da fisicalidade e da aura, por exemplo, não eram de suma importância. Suas estratégias e motivações se desdobram de uma forma diferente dos compositores das décadas seguintes que também trabalharam em direção a uma escrita radicalmente idiomática ${ }^{3}$. No que concerne a consciência do componente do hábito e do tonalismo em cada objeto sonoro que percebemos, também tornou-se consciente e diferenciada, bem como as predisposições sociais e históricas em relação às decisões tomadas pelo compositor no momento e local onde ele habita.

Compor enquanto resistência ao conceito de material prevalecente significa: lan-

\footnotetext{
${ }^{26}$ Tatsächlich zeigt die Untersuchung von Werken der klassischen seriellen Stilperiode, etwa die des Canto sospeso oder der Incontri von Luigi Nono, der Structures oder des Marteau von Boulez, der Gruppen oder der Kontra-Punkte von Stockhausen, daß die Stringenz dieser Musik sich nicht einfach der tugendhaften Konsequenz verdankt, mit der selbstgewählten Regeln durchgehalten werden und funktionieren, sodern mindestens so sehr der Weisheit, mit der die Musik selbst mit Hilfe solcher Regelsysteme - und im dialektischen Umgang damit - auf die gesellschaftlich vorgegebenen Strukturen und bereits geltenden kommunikativen Spielregeln des jeweils von ihnen in Gang gesetzten bürgerlichen ästhetischen Apparats reagiert, ihnen nicht bloß deklamatorisch, sondern konkret Widerstand leistet, das heißt: ihr geläufiges Funktionieren außer Kraft setzt, sie zuweilen gar zertrümmert. In diesem ihrem Widerstand gegen das Eingeschliffene lag die bis heute ungebrochene Kraft jenes historischen ästhetischen Ausbruchs und Aufbruchs und die Schönheit dieser Werke zu einer Zeit, als der von der Tradition verwaltete Begriff 'Schönheit' den meisten dieser junger Komponisten suspekt zu sein schien."

${ }^{3} \mathrm{O}$ termo 'idiomático', ou 'idioma', em textos sobre música, pode se referir tanto ao idioma de um instrumento ou uma técnica instrumental (como na expressão aqui empregada 'radicalmente idiomática', que explora ao máximo o universo de um instrumento), como também pode ser um sinônimo para estilo (como na expressão 'não-idiomática', para expressar a negação de qualquer estilo).
} 
çar nova luz sobre este conceito de material, iluminando-o assim para revelar e criar sensibilização do que é suprimido nele. [...] Escuta significa: mudar e redescobrir-se através desta capacidade de mudar. É na mudança da abordagem ao material que o compositor se expressa, se descobrindo como parte de uma realidade burguesa que possui muito mais camadas do que aquela mais visível. (Lachenmann 2004)

\subsection{Quatro aspectos fundamentais da escuta musical}

Os quatro aspectos fundamentais da escuta musical, segundo Lachenmann, são: o hábito e a tradição 3.1.1); a fisicalidade do fenômeno acústico e físico (3.1.2); a estruturalidade (3.1.3); a aura (3.1.4) do objeto musical (Lachenmann 2004, p.54-62). Tais aspectos estão presentes em todo objeto musical e são percebidos instantaneamente e intuitivamente pelo ouvinte.

\subsubsection{Tradição e Hábito}

Todo elemento que é captado pelo nosso aparato auditivo está sujeito (e é moldado em sua própria definição) pela nossa tradição ou em relação a ela. O que na cultura ocidental pode ser um fenômeno complexo, mas que inevitavelmente estará fortemente ligada à tonalidade, ou à "tonalidade" em um sentido mais amplo do termo: a tudo aquilo que a tradição tonal construiu. Toda uma "altamente complexa e polivalente dialética" (Lachenmann 2004, p.54) entre consonância e dissonância; relações de alturas tonais, atonais ou microtonais; som familiar ou não familiar; som harmônico ou ruidoso; modos de tocar tradicionais ou desconhecidos; instrumentos familiares ou não familiares e inúmeras outras áreas de tensões que os sons estabelecem em si e entre si causadas por predisposições sociais, históricas e materiais. Além de todas as convenções ligadas a essa tradição, à canção, à "prática do acompanhamento" ( $i d e m$.)e às formas tradicionais de um modo geral. 


\subsubsection{Fisicalidade}

Ao mesmo tempo todo objeto musical é também percebido como um estímulo corpóreo imediato trazido por informações físicas. Este aspecto, segundo Lachenmann, estará sempre em atrito com o primeiro, em ambivalência. Qualquer tentativa para que este aspecto venha à tona só será possível quando ele seja tão óbvio que não se perceba sua existência, pois estará encoberto pela convenção. Esses dois aspectos são mutuamente excludentes, como polos magnéticos opostos: para se perceber um o outro deve ser atenuado, para se perceber o aspecto energético, físico, o puro fenômeno acústico necessariamente deverá existir alguma força que contradiga a tradição e o hábito. Isso pode ser percebido não só em resistências radicalmente fortes, mas mesmo no repertório tonal e tradicional, por vezes surgem pequenas resistências que fazem o aspecto da fisicalidade ser percebido.

A Sonata D.960 de Franz Schubert (fig. 3.1), por exemplo, em seus momentos de maior quebra com a estandardização, tanto do estilo musical da época, quanto do uso do instrumento, o aspecto da fisicalidade é revelado. Notem como em um instrumento de épocaf a figura de trinado no registro grave soa muito pouco familiar e habitual, tanto pela sua quebra com a estandardização estilística quanto pelo uso de um registro inesperado, que nesse instrumento possuía um timbre mais metálico e duro comparado aos pianos modernos.

\footnotetext{
${ }^{4}$ Hammerflügel do início do século XIX, Viena.
} 

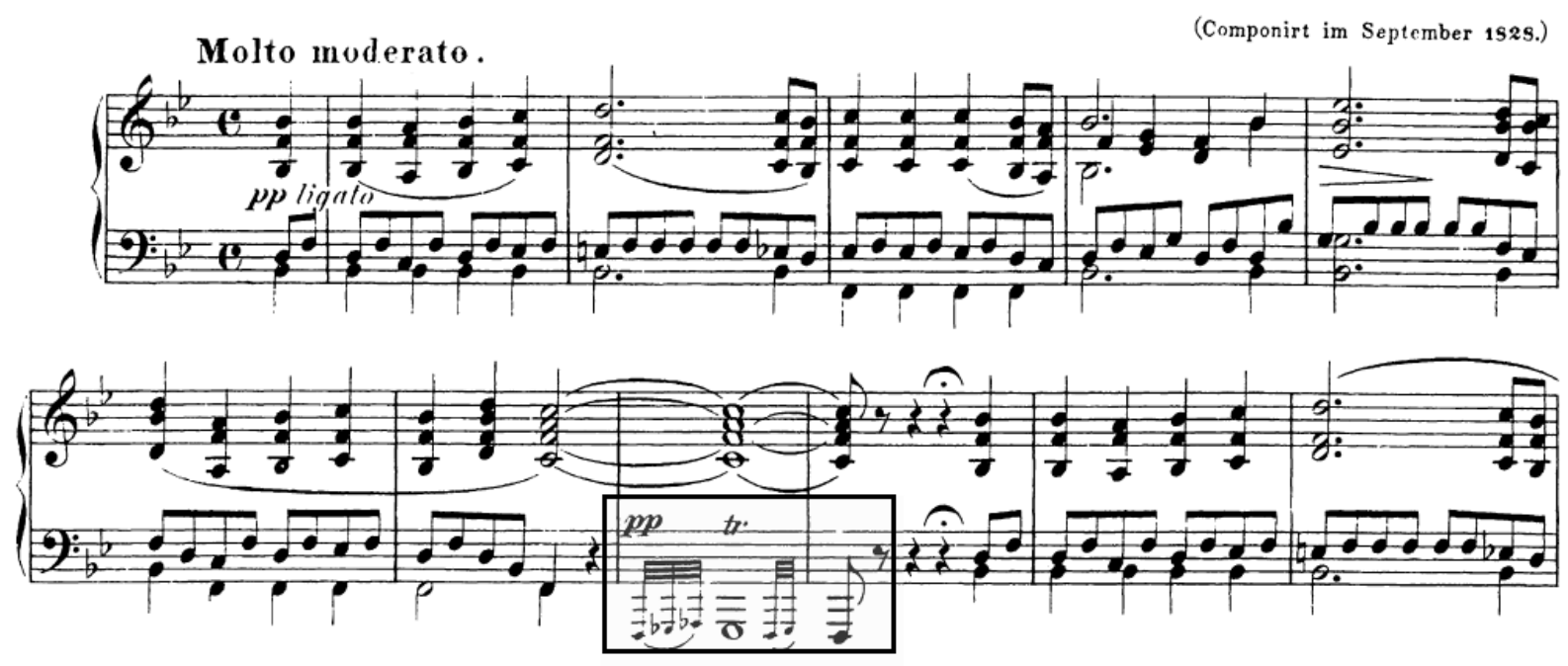

Figura 3.1: Sonata D.960 de Franz Schubert

\subsubsection{Estruturalidade}

O terceiro aspecto fundamental não entra em atrito com nenhum outro, ao contrário dos dois anteriores. Lachenmann o define como a estruturalidade do som enquanto um produto individualizado de sistemas, regras, leis e constelações temporalmente articuladas. Ou seja, é a função do objeto em um determinado contexto, tendência ou algum tipo de organização temporal.

\subsubsection{Aura}

A aura de um som é tudo aquilo que um som pode remeter ao ouvinte, tanto para um indivíduo quanto para um grupo de pessoas. Nos sons podem estar presentes ou ausentes referências reconhecíveis que apontam para contextos extramusicais. Tais contextos podem ser entendidos através de nossas esferas de experiências sociais e culturais, nossa memoria de eventos. Algo importante para caracterizar a aura é a qualidade de um som remeter a uma situação, ideia, objeto ou algo não relacionado diretamente à música de um modo instantâneo, que ocorre imediatamente durante a escuta musical, sem ser submetido a uma reflexão adicional da nossa consciência.

Um exemplo deste tipo de atribuição feita por Lachenmann é a comparação que este faz entre o uso dos cowbells nas obras Gruppen de Stockhausen e na Sexta Sinfonia de 
Gustav Mahler. Apesar do elogio de Lachenmann à obra de Stockhausen pelo seu "dinamismo na interação entre timbre e estrutura", ele o critica por "tratar os instrumentos somente como entidades acústicas, menosprezando sua aura cultural". Em Über das Komponieren Lachenmann (2004, p.75) ressalva que os cowbells na Sexta Sinfonia de Mahler não são meros "componentes acusticamente funcionais de uma estrutura", mas sim evocam, para um morador de cidade grande em viagem ao campo, "uma paisagem transfigurada, mais próxima do céu, com um ar mais puro".

\subsection{Desmantelamento da técnica instrumental}

No caso de um conceito de material que coloque a corporalidade em uma categoria mais próxima às das outras dimensões da composição, assim como aborde o gesto a partir de seu aspecto figural voltado à geração de material, que tipo de notação seria a mais indicada? Tanto em Helmut Lachenmann quanto em Klaus K. Hübler as indicações contidas na notação musical se referem muitas vezes às ações que o intérprete deve efetuar, e não necessariamente ao resultado esperado. Isso abre toda uma nova dimensão a ser levada em consideração, principalmente quando os elementos constituintes da técnica instrumental são dissociados (Alberman 2005, Kanno 2007).

É claro que há tanto elementos descritivos quanto prescritivos em toda notação musical, mas a questão se refere principalmente à predominância, às funções e à independência entre os elementos corporais constituintes do gesto. Em compositores como Klaus K. Hübler, Richard Barrett e Aaron Cassidy encontramos uma atenção detalhada e delicada entre os diversos parâmetros correspondentes às ações corporais, atuando em trajetórias muitas vezes independentes e postas em conjunto "como em um ensemble de músicos, e para um contínuo fluxo e deslocamento do poder expressivo entre eles" (Kanno 2007, p.252)

Lachenmann pode ser citado como um pioneiro a explorar esta área, inclusive a

5"The work ['The Crunch of Memory' de Aaron Cassidy] draws the performer's attention to a delicate balance between the parameters in the process of putting-together like an ensemble of musicians, and to a continuous shift and fluctuations of expressive power between them. One of the outcomes of this process is a greater realization of the expressive significance of the bow." 
independência rítmica entre diferentes parâmetros das ações do intérprete. Devemos entender também que as técnicas tradicionais já são em si mesmas complexas e "polifônicas", pois já são uma conjunto complexo de ações físicas codificadas, encapsuladas e indissociáveis de uma "técnica". Tais relações entre as ações físicas são transmitidas pela tradição da interpretação. Quando o compositor diferencia tais estratos simultâneos do gesto físico ele tem acesso ao material não mais como um alfabeto de técnicas, em si altamente complexas - porém indiferenciadas internamente - transmitidas pela tradição da interpretação (espressivo, furioso, dolce, teneramente, morendo). Percebese a complexidade que tais técnicas podem conter ao percebermos o trabalho envolvido ao se tentar reconstruí-las através da descrição de seus componentes internos. A esse respeito o violinista David Alberman aponta que:

[... uma importante apreensão da história conceitual das técnicas de Lachenmann é a divisão e desmantelamento das partes componentes de cada técnica. Por tal eu quero dizer que técnicas clássicas estabelecidas e normais consistem em combinações particulares das ações da mão esquerda e da mão direita do instrumentista. Por exemplo: um dolce clássico, com som legato é produzido com um vibrato (técnica da mão esquerda) e também pressão e velocidade do arco, inclinação do arco e o ponto de contato do arco na corda entre o cavalete e o espelho (ou seja, técnica da mão direita). Lachenmann separou tais elementos [... e usa pautas diferentes para as ações da mão direita e da mão esquerda; o que proporciona ao compositor determinar, inclusive, que as mãos devem ser ritmicamente independentes. (Alberman 2005)

A figura 3.2 ilustra a diferenciação interna do gesto físico do músico. Os dois pentagramas superiores correspondem ao primeiro violino; os dois inferiores, ao segundo violino

\footnotetext{
6"[...] one important insight into the conceptual history of Lachenmann's techniques is the division and dismantling of the component parts of each technique. By that I mean that established and normal classical techniques consist of particular combinations of left-hand and right-hand activity. For instance: a classical dolce, legato sound is made up of vibrato (i.e. left-hand technique) and bow speed, bow inclination and the contact point of the bow on the string between the bridge and the fingerboard (i.e. right-hand technique). Lachenmann has separated out these elements (whether 'deconstructed' is the proper word is a question for another discussion) and uses different staves for left-hand and right-hand activity, which allows him, for instance, to specify that the hands should be rhythmically independent. Lachenmann's notation also allows him to make clear where he takes a sound which would be continuous in classical music, but which he has dissolved into its molecular parts.[...]"
} 
- cada qual com uma scordatura diferente. Note como as ações efetuadas pela mão esquerda (notas rápidas com pouca pressão do dedo) são notadas separadamente da ação prescrita para a mão direita, responsável pelo arco. A posição do arco no cavalete, as arcadas, as intensidades são determinadas separadamente da mão esquerda. O gesto da mão direita é responsável não só pela articulação da dinâmica ou de uma sutileza de timbre (um pouco mais sul tasto ou sul ponticello), mas pela correspondência entre a força requerida e o resultado sonoro, pois quando o arco se posiciona exatamente no local do cavalete tanto a força requerida não corresponderá à dinâmica resultante (eis o porquê da indicação “ 'fortississimo' ” entre aspas), quanto também o som deixará de ter uma altura definida (endossada na partitura com a indicação "fast tonloss"). Outro detalhe interessante a ser observado seria a pausa de semínima dentro de tercina na mão direita. Neste momento a mão esquerda segue seu gesto independentemente, porém sem um resultado sonoro considerável, o que poderia acontecer caso a pressão do dedo fosse normal ou percussiva. 


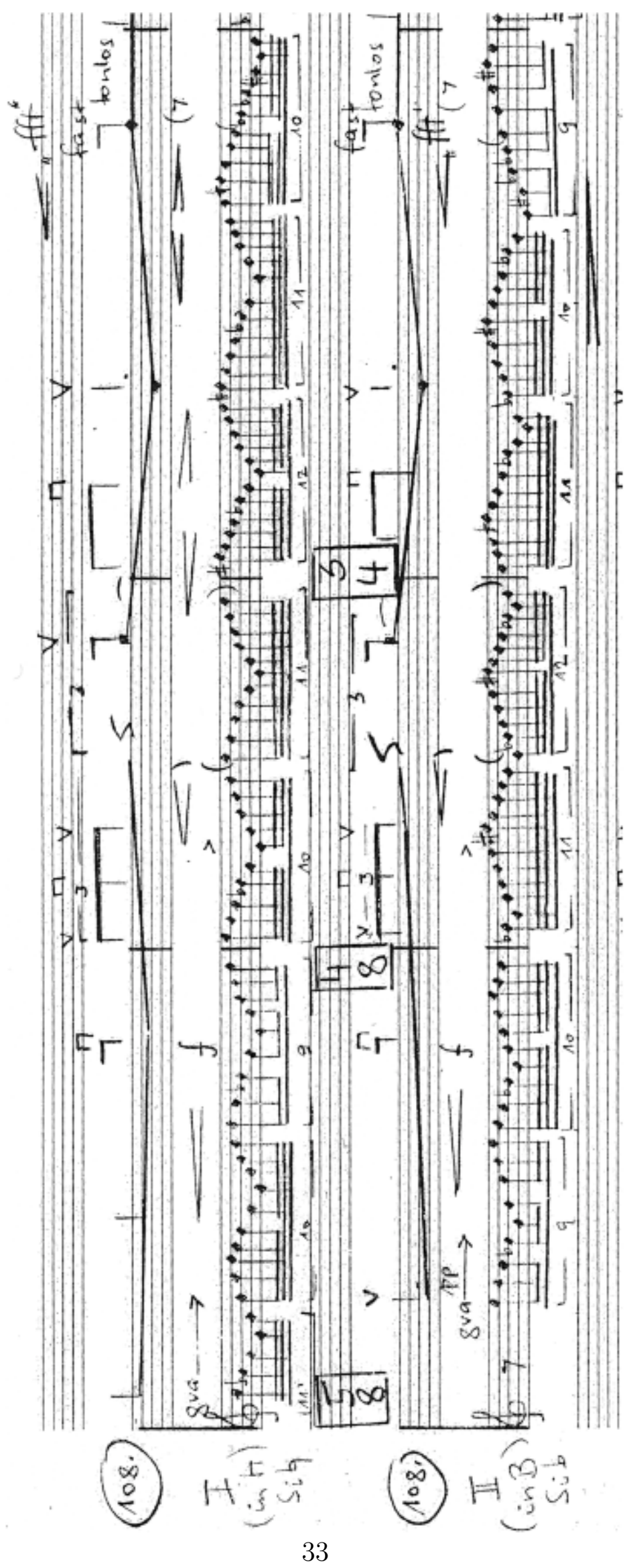

Figura 3.2: Segundo Quarteto de Cordas de Lachenmann: diferenciação dos componentes do gesto físico na notação musical 
A dissociação dos elementos da técnica instrumental inicialmente realizada por Lachenmann (Alberman 2005) foi reformulada em novos tipos de notação que permitiriam, em tese, a realização de uma gama muito grande de semantificaçõe $\mathrm{l}^{7}$ dos componentes da técnica instrumental. Ou seja, tratar tais componentes físicos e corpóreos como parâmetros da figuralidade dos gestos devidamente inseridos e significativos em um contexto musical. Assim aponta Klaus K. Hübler em seu artigo Expanding String Technique:

A história da Música Nova é marcada, em grande parte, pela indiferença por parte dos compositores aos instrumentos musicais e suas limitações. Por um lado, a escola do serialismo integral concebia os parâmetros composicionais com base em leis abstratas; as possibilidades técnicas específicas dos instrumentos eram consideradas, quando muito, empecilhos para a realização de um conceito gerativo [...] Nosso propósito aqui é pleitear um modo de composição para o instrumento em questão. Isto não implica um retorno a uma pseudo-naïveté simplista; antes, deve promover uma expansão do som e da técnica com raízes nos recursos específicos dos instrumentos e de seus modos de performance. Um exame crítico dos instrumentos e o enfoque na imaginação inovadora do potencial concreto dos instrumentos pode ser gratificante na medida em que isso abre uma perspectiva completamente nova sobre os instrumentos. ("Hübler 2004, p.233)

O que Hübler propõe aqui é o deslocamento da técnica instrumental para o centro

${ }^{7}$ Usamos o termo 'semantificação' não no sentido da produção de significados linguísticos, mas da geração de componentes significativos do ponto de vista do argumento musical.

8"Preliminary Remarks on the 'Spirit' [Geist] of Instruments. The history of New Music is marked to a large extend by the disregard of the instrument and its limitations. On the one hand, the serialist school conceived the compositional parameters on the basis of abstract laws; the specific technical possibilities of the instrument were considered at the most as an undesirable obstacle to the realization of the constructive concept. On the other hand, many sought to distort the sound quality of the instrument in an attempt to extirpate all the well-known, historical characteristics that the instrument had acquired through centuries of development. Both of these lines of thought shared one common feature: the conviction that the renewal of the sound potential and technique of the instruments could only be attained by a progressive rejection, either partial or in whole, of the traditional instrumental technique and performance style as we know it. Despite the occasionally interesting results, these tendencies gave rise to dissatisfaction. Instead of seeking to create a group of instruments suited to the new demands, one continued to use the classical instruments while simply ignoring their historical implications. Our purpose here is to plead for a manner of composition adapted to the instrument in question. This in no way implies a return to a simplistic pseudo-naïveté; rather, it should promote an expansion of sound and technique that has its roots in the specific resources of the instrument and in its manner of performance. A critical examination of the instrument and a focusing of the innovative imagination on the concrete potentials of the instrument can be rewarding to the degree that it opens a completely new perspective on the instrument" 
das preocupações composicionais. A abordagem de Hübler se difere da produção que o precede por propor uma dissociação dos componentes físicos constituintes de um mesmo gesto ainda mais radical que Helmut Lachenmann. Tal estratégia é o caminho que ele encontrou para, em suas próprias palavras, "promover uma expansão do som e da técnica com raízes nos recursos específicos dos instrumentos e de seus modos de performance, fazer uso do potencial concreto dos instrumentos" (Hübler 2004). 


\section{Capítulo 4}

\section{A Escrita Corporal}

O objetivo aqui é capturar a lei do desejo que faz música, que produz a escrita. Julia Kristeva.

Neste capítulo abordaremos a relação entre a notação musical e a corporalidade na música contemporânea. Primeiramente tentaremos demonstrar o papel da notação musical na composição, que, a nosso ver, extrapola a função de uma ferramenta de descrição, podendo também transmitir de modo mais sensível questões ligadas à integridade estética de uma obra musical. Em seguida abordaremos uma hierarquização herdada da tradição entre parâmetros "primários" e "secundários" — tomando-se emprestado a definição do compositor Pierre Boulę ${ }^{1}$ - da escrita (seção 4.2). Finalmente tentaremos demonstrar que o método da notação prescritiva pode revelar uma preocupação composicional especial em relação à corporalidade (seção 4.3).

\subsection{Notação}

Até que ponto é de fato relevante levantar a questão da notação e tentar relacioná-la à uma integridade estética e uma correspondência com outras questões composicionais mais profundas? Ferneyhough também crê que a notação mantém uma relação com as intenções do compositor, como aponta de maneira muito clara:

\footnotetext{
${ }^{1}$ Boulez, P. Boulez on Music Today apud. Wishart 1996
} 
Notação (particularment $\mathrm{2}^{2}$ notação) nos mostra duas faces: rastreável e analisável em termos de desenvolvimento histórico, como sem dúvida é; e,no entanto, dificilmente pode ser separada, mesmo em princípio, dos objetivos concretos que um determinado artista se propôs. Está longe de ser acidental que tantas obras das últimas três décadas são, talvez, mais imediatamente caracterizáveis em termos visuais do que pelas suas características sonoras. (Ferneyhough 1995, p.2) ${ }^{3}$

. O processo de notação deixa-se impregnar, reflete e expõe certas preocupações técnicas e estéticas do compositor. Na música contemporânea tal fato possui uma importância maior do que em épocas precedentes. Uma das grandes características da música produzida nos séculos XX e XXI é justamente a diversidade estilística. O mesmo não ocorreu em épocas anteriores, onde a notação estava mais firmemente fundamentada no todo de um processo de produção baseada em um estilo comum. Hoje as limitações de comunicações da notação musical se tornam mais evidentes justamente porque o trabalho de interpretação se tornou mais complexo. Desse ponto de vista, a integridade estética entre as representações visuais de uma composição e as intenções e desejos do compositor se torna mais importante.

O compositor francês Pierre Boulez também atestou a importância da notação para além da descrição do material, quando diz que a notação

[...] não constitui um elemento subalterno da linguagem, mas o principal; a notação associa a natureza do material à natureza do trabalho que atua sobre ela. A notação descreve o material, certamente; mas ela também remete à sua existência e sua elaboração. Daqui resulta que a natureza do material é revelada pela notação e as relações de mudança de material na qualidade de comparação com a invenção; a notação deve não somente refletir, mas exprimir essas mudanças profundas. (Boulez 2005)

\footnotetext{
${ }^{2} \mathrm{~A}$ ênfase foi dada pelo próprio Ferneyhough

3"Notation (particularly notation) shows us two faces: traceable and analyzable in terms of historic development as it doubtless is, it is nevertheless hardly to be separated, even in principle, from the actual goals which a particular artist has set himself. It is far from accidental that so many works of the last three decades are perhaps more immediately categorizable in terms of their visual rather then their aural characteristics."
} 
A relação da notação com o material iria além de uma ferramenta de descrição, mas está ligada diretamente a seu próprio processo de criação e à sua própria ontologia. Na opinião de Boulez a notação deve tentar exprimir tais propriedades, daí resultaria uma maior integridade estética, já que a notação estaria de acordo com outros componentes da obra.

\title{
4.2 Parâmetros "secundários"
}

Anteriormente nos referimos à diferenciação que Boulez realiza entre parâmetros "primários" e parâmetros "secundários". De fato nós relacionamos que essa diferenciação está relacionada ao impasse que o serialismo integral sofreu, e que tiveram de ser resolvidas por compositores que adotaram o conceito de parâmetro.

\begin{abstract}
Altura e duração me parecem constituir a base de um dialeto composicional, enquanto que intensidade e timbre pertencem a categorias secundárias [de parâmetros]. A história da prática musical universal testemunha a decrescente importância, como é confirmado pelas diferentes fases de desenvolvimento de notação. Sistemas de notação e ritmo sempre aparecem altamente desenvolvidos e coerentes, embora muitas vezes difícil de encontrar teorias codificadas para a dinâmica e timbre, que geralmente são deixadas ao pragmatismo ou à ética. $4_{4}^{4}$
\end{abstract}

Ao nosso ver, Ferneyhough realizou uma importante mudança conceitual não só pela sensibilização em relação ao gesto, mas também pela compreensão que o tipo de categorização utilizada por Boulez na citação acima é totalmente dependente de um contexto musical, e deve ser analisada caso a caso. Em certos contextos outros parâmetros podem ser até mais importantes que os parâmetros "primários"; como acreditamos ser o caso com a análise da peça Air no capítulo 6 .

\footnotetext{
4 'Pitch and duration seem to me to form the basis of a compositional dialectic, while intensity and timbre belong to secondary categories. The history of universal musical practice bears witness to this scale of decreasing importance, as is confirmed by the different stages of notational development. Systems of notating both pitch and rhythm always appear highly developed and coherent, while it is often difficult to find codified theories for dynamixs or timbre which are mostly left to pragmatism or ethics [...]" (Boulez, P. Boulez on Music Today, apud. Wishart, 1996, p.6)
} 


\subsection{Notação Prescritiva}

Como atestado por outros autores (Alberman 2005), Lachenmann foi o primeiro compositor a ter uma abordagem radical no que se refere tanto à notação prescritiva quanto ao desmantelamento da técnica instrumental em parâmetros relativos às ações do músico. Iremos tratar desses termos e questões com mais detalhes a seguir.

\subsubsection{Notação descritiva ou notação de resultado}

A notação descritiva, ou notação de resultado, pode ser entendida como uma tentativa de se construir um sistema que tenha como objetivo a descrição do resultado sonoro no eixo bidimensional (alturas e durações) da partitura. Uma partitura, nos períodos anteriores ao século XX, continha quase que exclusivamente informações relativas às alturas, ritmos, andamento, dinâmicas e algumas indicações verbais. Várias informações muito importantes para a performance eram suprimidas, pois deveriam ser deduzidas a partir das sugestões contidas nesses elementos mais facilmente inscritos em notações musical; assim como, dos contextos culturais e musicais do lugar e época em questão. Salvo exemplos retirados da tradição da notação musical por tablatura, a grande maioria das inscrições realizadas em notação musical se referem a indicações descritivas; são indicações relativas a uma descrição de um resultado requerido e, do ponto de vista de uma precisão sob esse aspecto, grosseiramente representada, pois mesmo para esses parâmetros, sem uma contextualização e uma tradição de interpretação musical para servir de base, dificilmente um intérprete chegaria a uma interpretação adequada.

Seria algo comparável a uma gravação sonora, que aspira o registro dos gestos musicais assim como eles soam ao ouvido, contendo toda a informação assim como ela deve chegar aos ouvidos. Isso permitiria, por exemplo, registrar uma sequência musical sem que haja nenhum tipo de preocupação com os meios materiais e com as ações que serão necessárias para se produzir esse resultado sonoro. Um tipo de notação totalmente descritiva não é difícil de ser imaginado, basta olhar incontáveis exemplos em textos primordialmente didáticos ou descritivos. Muitas das informações contidas em uma 
partitura podem ser apenas descritivas, como a notação de altura sem nenhuma indicação da ação requerida, ritmo registrado em notação métrica ou notação proporcional, intensidade sonora em um sentido absoluto, e não relativa ao esforço físico requerido, assim como textos descritivos. Tais elementos são de grande relevância na tradição da música ocidental e não fortemente integrados no ofício dos músicos. É esperado de um músico profissional que ele possa mentalmente decodificar uma partitura e saber o resultado sonoro que aqueles símbolos querem representar.

Uma experiência interessante pode ocorrer quando utilizamos programas de computador escritos especialmente para a notação musical, o que em muitos casos também permitem que a partitura seja convertida em um arquivo MIDI ou um aparato de reprodução. Nesse instante percebemos duas coisas interessantes: primeiramente que a partitura possui, de fato, uma grande quantidade de informação capaz de fazer com que uma máquina desprovida de inteligência realize uma execução daquelas informações. Mas ao mesmo tempo percebemos que nem todas as informações estão registradas nesse código, talvez nem mesmo a metade. Há vários motivos e explicações para esse fato. Um deles é que a notação musical sempre está inserida em um contexto e em uma tradição de interpretação e também possui o seu próprio processo de transformação e reinterpretação ao longo da História. Podemos citar inúmeros exemplos disso, um deles, apontado por Kanno (2003) é, por exemplo, o ajustamento microtonal das alturas de acordo com contextos harmônicos e contrapontísticos. Ou o conceito de "bom som", que na verdade é apenas uma instância de um complexo jogo da técnica instrumental. Ou como nos afirma o compositor francês François Couperin: "como há uma grande distância entre a gramática e a declamação; há também entre a tablatura e a maneira de bem-tocar" 5

Como mencionamos há pouco, tais convenções não são estáticas, antes são passíveis de mudanças mais ou menos rápidas no decorrer do tempo, o que eventualmente acarre-

\footnotetext{
${ }^{5}$ Couperin, F. L'Art de toucher le clavecin, Paris, L'auteur, Foucaut, 1717, prefácio. Reimpressão: New York, Brounde Brothers limited, 1969; apud Bouissou. Também disponível em http:// imslp.org/wiki/L'Art_de_Toucher_le_Clavecin_(Couperin,_François)
} 
tam novas áreas de estudo para arcar com os desafios de se interpretar músicas escritas em épocas anteriores à gravação sonora, ou pobremente registradas. Tais mudanças, entretanto, na maioria das vezes são realmente muito lentas para serem percebidas por apenas uma geração de músicos, o que muitas vezes acaba criando a sensação de que a prática de interpretação atual seria pura e simplesmente uma convenção absoluta e totalmente fiel às origens daquele repertório em questão. Isso nos coloca em uma posição na qual uma interpretação mais precisa, segundo esse ponto de vista, não seria aquela realizada por um computador digital, mas sim pela obediência estrita às regras herdadas de certa tradição de interpretação que a notação surge por motivos históricos. Porém, isso cria um novo impasse, pois somente partituras que estiverem em total acordo com as regras da convenção é que serão passíveis de uma interpretação precisa. Esse raramente é o fato da maioria das obras do repertório da música contemporânea. O que ocorre, muitas vezes, é que certos problemas que surgem no processo de interpretação de uma partitura de música contemporânea são justamente aqueles problemas implícitos em qualquer método de notação musical. O que leva alguns importantes compositores, como Karlheinz Stockhausen, somente considerarem seu trabalho encerrado quando conseguem uma gravação adequada de sua obra. Do ponto de vista desses compositores, no nosso atual estágio tecnológico, somente o registro sonoro pode suprir as deficiências contidas na notação, mesmo que não elimine sua necessidade e suas contribuições únicas ainda insubstituíveis. Outro exemplo desse fenômeno é que é algo absolutamente esperado que intérpretes entrem em contato diretamente com compositores para obter mais informações que ajudem em seus processos de interpretação de uma peça musical.

Segundo a violinista Mieko Kanno, a notação de resultado, ou descritiva, é caracterizada por dois grandes fatores:

- uma notação de resultado somente se torna estabelecida e amplamente aceita quando o som que ela intenta representar já é de fato claramente entendido pelo compositor; 
- a representação de um som, gesto ou objeto sonoro só pode ser adequado e servir ao seu propósito de realização se já for bem estabelecido na prática instrumental.

Ela nos dá um exemplo excelente para ilustrar a relação entre a interação entre a prática da composição e da notação. Trata-se de uma técnica violinística introduzida por Szymanowski e Konchanski, que é registrada na partitura como uma combinação das técnicas do glissando e da técnica do trinado. Uma outra abordagem para esse tipo de notação seria muito difícil, caso a partitura fosse realizada tentando estabelecer todas as alturas que essa combinação de ações acarreta. A notação seria mais problemática tanto para o compositor quanto para o intérprete. Ela sugere, então, que há uma clara relação entre uma descrição bem sucedida do som em notação musical e, eventualmente, uma maior adoção desse tipo de notação para aquela situação. Porém tal procedimento nem sempre pode ser utilizado em todas as ocasiões, pois poucos sons são de fato absorvidos pela norma da notação, assim como "nem todos os sons podem ser 'descritos'" (p.234). Há uma lacuna enorme entre "os sons disponíveis por um lado e o vocabulário limitado em notação por outro, onde a inadequação da notação é difícil de ser ignorada". Essas limitações, principalmente a primeira, são difíceis de serem evitadas, e contribuem, segundo Kanno, para os maneirismos e cacoetes na performance.

\subsubsection{Notação prescritiva ou notação de ação}

O exemplo dado por Mieko Kanno sobre a técnica instrumental introduzida por Szymanowski possui componentes de notação prescritiva. O glissando é uma forma de notação que descreve uma mudança contínua na altura de um som, já o trinado é uma indicação de uma ação a ser efetuada. A notação prescritiva consiste em uma partitura em que o compositor especifica as ações e os procedimentos para que um certo resultado sonoro seja alcançado, como uma receita ou uma lista de ações, mesmo que o resultado final não seja muito claro, os passos possivelmente darão ao intérprete recursos suficiente para uma performance adequada. "Notação prescritiva nos diz o que devemos fazer com a mente, o corpo e o instrumento para que se produza os sons de uma obra musical" (Kanno 2007, p.235). Coisas triviais como a indicação de um harmônico 
não pela altura resultante, mas pela posição necessária para a produção desta altura, por exemplo, podem ser consideradas como um tipo de notação prescritiva. Pode-se pensar nas razões originais para o surgimento de cada um dessas técnicas de notação prescritiva. O tremolo e a surdina, por exemplo, foram introduzidos durante o século XVII, período no qual houve o grande desenvolvimento da técnica para instrumentos de cordas friccionadas. Assim como no caso de compositores recentes como Lachenmann, Sciarrino, Barrett ou Cassidy, há uma tendência para o que chamamos anteriormente de semantificação da técnica instrumental na segunda metade do século XX, cujos desdobramentos se estendem até os dias de hoje. Definindo de modo breve o que seria a semantificação da técnica instrumental, trata-se do uso dos recursos materiais, físicos do instrumento e das ações corporais do instrumentista como componentes indispensáveis para uma realização adequada de uma proposta de argumento musical, ao contrário de um discurso onde as alturas e as durações dão conta de transmitir a ideia, e onde os demais parâmetros são tratados apenas como elementos que destacam, acentuam, pontuam, ou deixam mais claro o encadeamento musical.

\subsubsection{Notação prescritiva em Lachenmann}

As obras de Lachenmann do início da década de 1960 - como Fünf Strophen (1961) e Angelion (1962/3) — ainda apontam para uma concepção de material musical próxima das representações mais abstratas do serialismo integral, em linhas análogas a compositores como Luigi Nono. O musicólogo Richard Toop (Toop 2004) $)^{6}$ aponta que em Introversion II (1963), em certos momentos, especialmente na parte de contrabaixo, já se prenuncia sua "visão radical de produção sonora" que emergiria em sua plenitude apenas alguns anos depois; muito embora a "representação dos eventos musicais ainda permanecessem bastante abstratas". Outra obra importante neste processo de formação da musique concrète instrumental 7 seria Notturno (1966), obra com o subtítulo "mú-

\footnotetext{
${ }^{6}$ Toop, R. Concept and context: a historiographic consideration of Lachenmann's orchestral works. Contemporary Music Review, v. 23, n. 3-4, p. 125-143, 2004.

${ }^{7}$ Termo utilizado pelo próprio Lachenmann em seus textos do final da década de 1960 e começo da década de 1970 para descrever suas obras mais radicais no sentido da fisicalidade e que pertencem à primeira fase do seu trabalho composicional.
} 
sica para pequena orquestra com violoncelo solo". Nesta obra Lachenmann já apresenta diferenciações em relação aos seus modelos da Escola de Darmstadt, os sons apresentam certas características que diferem de um pontilhismo clássico, de um espaço de ataques; já as 'notas' possuem uma trajetória interna constituindo uma escritura em direção a um espaço de eventos: crescendi, diminuendi, glissandi etc. Na cadência que dura oito minutos (que se inicia já no quarto minuto de uma obra que tem duração total de dezoito) Toop vê os indícios do que viria a ser Pression: "testemunha-se não tanto o instrumentista virtuoso, mas sim o explorador sonoro virtuoso (compositor e intérprete). [...] Quando a orquestra retoma, é quase como se a música do solista tivesse se transformado em um vírus que progressivamente e sem remorso infecta todos os outros instrumentistas" (Toop 2004, p129- 130).

A renovação paradigmática em direção à ênfase na fisicalidade da produção sonora ocorreu no ano seguinte ao conturbado ano de 1968, caracterizado por mudanças sociais fundamentais no mundo e repleto de acontecimentos históricos importantes. Air ${ }^{8}(1968-$ 1969, para grande orquestra e percussionista solo) foi executada primeiramente nos Cursos de Verão de Darmstadt do mesmo ano.

Toop ainda aponta que, paradoxalmente, apesar das diferenças ideológicas gritantes entre o jovem Lachenmann e Stockhausen, em termos de ênfase na fisicalidade da produção sonora, os dois não poderiam estar mais próximos, especialmente se tivermos em mente obras como Aus den Sieben Tagen ou Mikrophonie I (do compositor Stockhausen), muito embora estas obras apresentem uma manipulação de amplificação via mesa de mixagem, fator este que Lachenmann continuou a evitar nas obras posteriores.

Cabe aqui também rememorar o mérito de Stockhausen que nesse mesmo período apontou sua produção de um modo completamente diferente, e por razões diferentes das de Lachenmann, indicou caminhos para questões da fisicalidade e da corporalidade, e mesmo, até um certo ponto, da notação de ação (como na obra já citada Mikropho-

\footnotetext{
${ }^{8}$ A obra Air do compositor Lachenmann tratada no presente capítulo não deve ser confundida com a obra Air do compositor Richard Barrett, que será analisada no capítulo 6
} 
nie I). Em um primeiro momento no processo de composição Stockhausen começou a produzir uma notação altamente voltada para a prescrição: "primeiro peguei as ações [...] inicialmente trabalhei em uma partitura que dava instruções tais como "pegue uma caixa de plástico [...] segure-a contra a superfície do tam-tam a um ângulo específico (e tentava descrever o ângulo), e então arranhe-a com um movimento rápido [...]" (Stockhausen 2009, p.76). Ou sobre a importância da gesticulação e coreografia em obras como Harlekin ou Inori. Além de outras ocasiões posteriores, já nos anos 1980, como atestam suas visões sobre a construção de um estúdio eletrônico (ou eletroacústico) para seu trabalho, como na passagem que se refere a um equipamento de época que "[...] ainda é o instrumento que mais gosto, porque permite que as velocidades e os registros de todos os parâmetros sejam manipulados em tempo real, por meio de teclados, joysticks e um monte de botões. Essa habilidade de influenciar todos os parâmetros no momento em que se escuta será um requisito essencial para a música eletrônica do futuro. E também para a composição instrumental" (Stockhausen 2009, p.106). Ao dizer isso Stockhausen anunciou de fato certas tendências atuais decorrentes do desenvolvimento de computadores e programas muito mais sofisticados do que nos anos 1980, e que deslocou parte da produção da música eletrônica do estúdio para o palco.

As influências de Stockhausen e Nono na obra de Lachenmann são curiosamente diferentes neste período final da década de 1960. Stockhausen parece ter influenciado Lachenmann pelo viés do material e da ênfase na fisicalidade da produção sonora, embora ambos estivessem distantes ideologicamente; já Luigi Nono parece ter influenciado Lachenmann no que compete às questões éticas da composição musical, embora estivessem distantes no aspecto da fisicalidade.

Além da referida ênfase na produção física do som, que já estava sendo anunciada em obras anteriores, ressaltamos para outros dois pontos importantes nas obras de Lachenmann: o aspecto "provocativo" de um conceito de material que não corresponde 
ao gosto burguês $\mathrm{s}^{9}$ e o grande refinamento no uso dos instrumentos da orquestra de uma obra como Air, como apontou o compositor Walter Zimmermann, presente na estreia: "Foi um tipo de revelação, eu nunca tinha ouvido uma peça orquestral com tamanho refinamento sonoro, 10 , Assim como em Notturno o material do violoncelo solista teve — citando o termo usado por Richard Toop - um papel de "vírus", como ocorreu com o percussionista solista em Air:

A transferência da mentalidade da percussão para a orquestra é refletida na notação, que se torna quase que inteiramente uma notação de ação [ou notação prescritiva]: uma indicação do que deve ser feito em lugar do resultado sonoro. O mesmo se aplica às dinâmicas, que frequentemente refletem o vigor da ação, mais do que o volume sonoro do mesmo na notação. (Toop 2004, p.131) 11

Esta relação de contaminação presente na parte da percussão, bem como a fisicalidade da produção sonora concebidas enquanto material — em lugar de uma concepção abstrata de material — , foram permanente e representaram de fato uma virada estética fundamental. No ano seguinte, 1970, a obra Kontrakadenz, escrita para uma orquestra em grande parte similar a Air, sem a presença de um solista, apresenta a mesma tendência: refinamento das técnicas instrumentais empregadas e a mudança de paradigma, onde o trabalho volta-se não mais para o espaço de ataques do pontilhismo dos anos de 1950, mas sim para um espaço de eventos, onde a informação não está apenas

\footnotetext{
${ }^{9}$ No texto $O$ Belo na Música Hoje Lachenmann discorre sobre a concepção do belo e sobre o aparato estético vigente na música. O conceito de burguesia que Lachenmann utiliza tem origem em autores como Christopher Cauldwell no seu texto O Belo e Estética Burguesas. Lachenmann em seu texto diferencia o conceito burguês de belo (visto pela vanguarda com muita suspeita) da sua própria concepção de belo, que relaciona o belo ao novo, redefinindo a experiência estética e conciliando a estética modernista com o seu próprio conceito de belo. Em homenagem a Cauldwell, Lachenmann compôs em 1977 Salut für Cauldwell para dois violões, utilizando textos do autor.

${ }^{10}$ Comunicação pessoal de Walter Zimmermann a Richard Toop em 1 jan. de 2004 (Toop 2004 p.131).

11“The transference of a percussion mentality to the orchestra is reflected in the notation, which becomes almost entirely an action notation: an indication of what is to be done rather than the sounding result. The same largely holds for the dynamics, which often reflect the vigour of the action, rather than the loudness of the outcome (in any case, in many instances what is affected here is pitch rather then volume). In short, the whole act of performance is emphatically physicalised, even in the score: in this respect, Air remains one of Lachenmann's most radical works."
} 
nos parâmetros tradicionais (altura, intensidade, timbre, duração e alocação temporal), mas também num contexto onde cada evento é entendido como uma trajetória multidimensional.

\subsection{Consideraçõs finais: escritura musical e o corpo}

A notação prescritiva pode ser entendida como um sintoma de que a escritura musical abarca e extrapola os parâmetros mais tradicionais da notação musical. O que não significa que na ausência da notação prescritiva não haja a intervenção de importantes vetores que ajam nas inter-relações entre os diversos parâmetros, mas antes deve ser entendida como uma necessidade do compositor de ter acesso mais direto e expor mais claramente suas intenções no que concernem as ações físicas do intérprete. Poderíamos ir mais adiante e afirmar que a escritura musical vai além até mesmo de qualquer forma de inscrição musical. Por um lado porque a inscrição musical estará sempre ancorada em um fundo de práticas interpretativas e culturais. Por outro lado porque por mais completa que seja a inscrição musical, ela sempre deixará tendências implícitas a serem preenchidas por um trabalho de interpretação posterior. Neste capítulo tentamos chamar a atenção para alguns desses aspectos acerca da relação entre a escritura, a notação musical e a corporalidade. Tais apontamentos serão úteis na parte III, reservada às análises musicais. 


\section{Parte II}

\section{Análises Musicais}




\section{Análises Musicais}

Na parte [I] que segue iremos analisar certas obras que cremos ser especialmente relevantes para demonstrar certas propriedades do gesto físico e da corporalidade que temos em mente. No capítulo 5 analisaremos um conjunto de peças para teclado (piano e cravo). No capítulo 6 analisaremos a obra Air para violino solo de Richard Barrett. 


\section{Capítulo 5}

\section{Fisicalidade em obras para teclado}

Neste capítulo faremos uma investigação sobre o aspecto da fisicalidade, especialmente no repertório para cravo e piano. Serão analisados alguns excertos de músicas dos compositores Domenico Scarlatti (seção 5.1), Frédéric Chopin (seção 5.2), Robert Schumann, Michael Finnissy (seção 5.3), além de uma análise mais detalhada das $V a-$ riações op.27 de Anton Webern (seção 5.4).

\subsection{Domenico Scarlatti}

O compositor e cravista italiano Domenico Scarlatti, durante seus últimos anos de vida, compôs aproximadamente duzentas peças para o seu instrumento . Tais obras correspondem ao que conhecemos hoje como Sonatas. Gostaríamos de chamar atenção no presente estudo para a diferença na recepção e interpretação dessas obras. Tal diferença de interpretação, a nosso ver, possui um forte vínculo com a tese central da pesquisa.

Algo interessante acontece na transcrição que certos editores e pianistas fazem de tais obras, onde além de ignorar os pontos mencionados acima - em relação à tensão com o material disponível - também ignoram as indicações relativas ao gesto físico, o que de certa forma oculta o conceito de material original da obra. Algumas alterações de editores demonstram uma leitura totalmente distorcida destas peças no que concerne aos seus gestos físicos. Segundo John Sankey (Sankey 2009), as indicações de mãos 
realizadas por Alessandro Longd $\mathrm{d}^{1}$ em 1906 foram realizadas sem a devida informação histórica adequada. Sankey realizou uma nova edição considerando tais indicações de mão do manuscrito, ou inferindo a partir de padrões do estilo. Um dos casos mais evidentes, também apontado por outros autores (Cassidy 2004, Sankey 2009) ocorre na Sonata K.120 (figura 5.1):
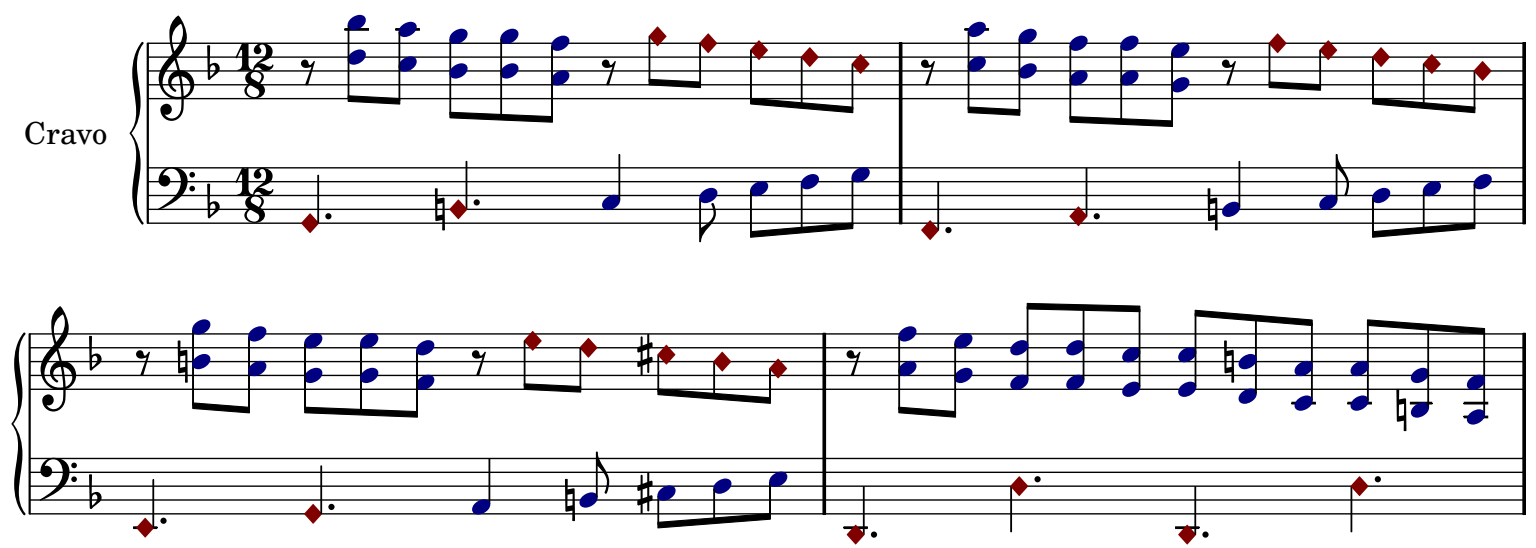

Figura 5.1: Sonata K.120 de Domenico Scarlatti (edição de John Sankey)

Tais indicações não constam em muitas edições. Notemos que neste excerto, apesar do material referente aos ritmos e alturas se manter estável, o compositor determina de uma maneira surpreendente a mão com a qual se deve tocar cada nota. O mesmo trecho sem estas indicações teria uma intenção e um resultado muito distinto. O gesto físico (a ação) e a coreografia(a percepção visual da ação) assumem um papel morfológico importante, assim como as alturas, as articulações, os ritmos etc. A nosso ver, Scarlatti levou em consideração as ações físicas como intrinsecamente conectadas ao resultado sonoro e legítimas componentes do material composicional de modo geral. Aí está uma das propriedades importantes de seu estilo exuberante de tocar o cravo. Outro exemplo seria a Sonata K.54 (figuras 5.2, 5.3 e 5.4).

\footnotetext{
${ }^{1}$ Alessandro Longo (1864-1945) foi um compositor e musicólogo italiano que catalogou um grande número de obras de Domenico Scarlatti.

${ }^{2}$ Nesta edição as cabeças de notas em forma de diamantes e vermelhas devem ser tocadas com a mão esquerda; já as com cabeça de notas arredondadas e azuis, com a mão direita.
} 

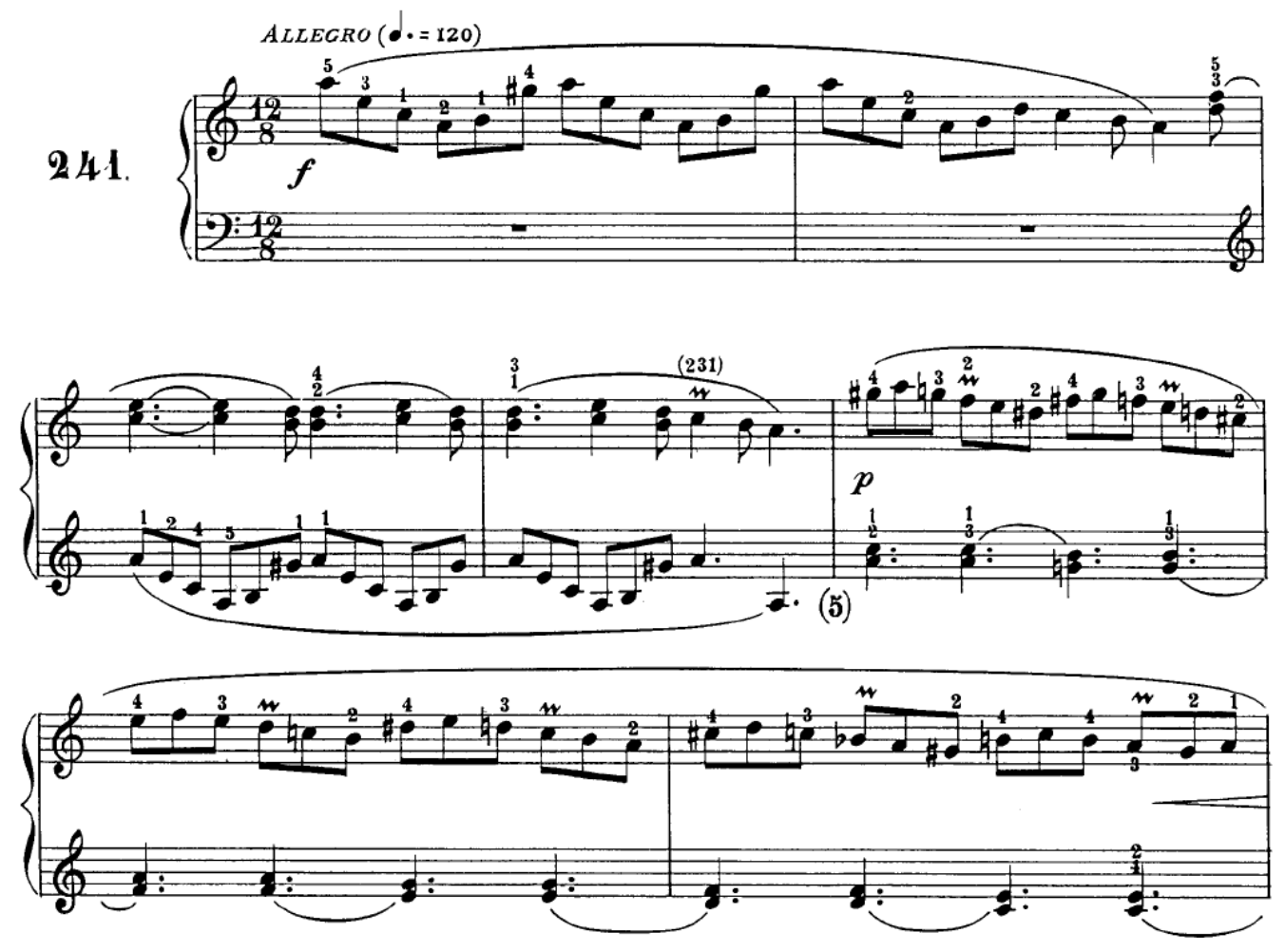

Figura 5.2: Trecho da Sonata K.54 (edição de Alessandro Longo)

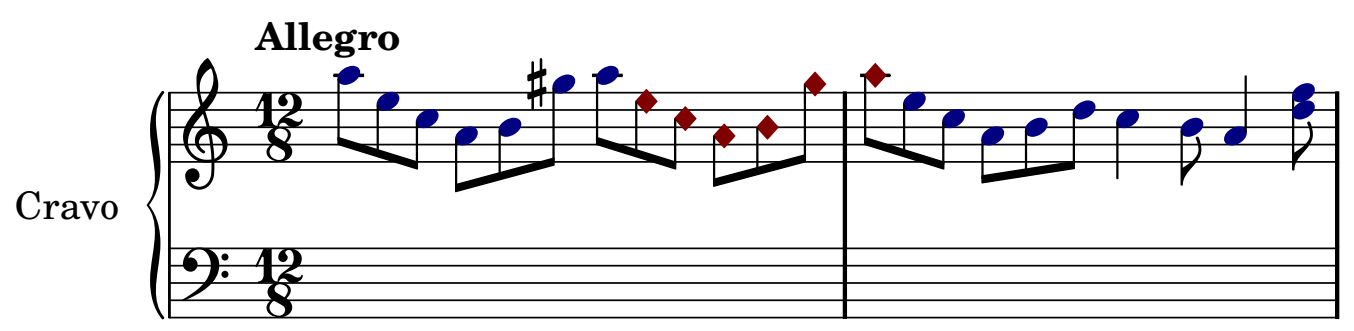

Figura 5.3: Trecho inicial da Sonata K.54 de D. Scarlatti (edição de John Sankey)

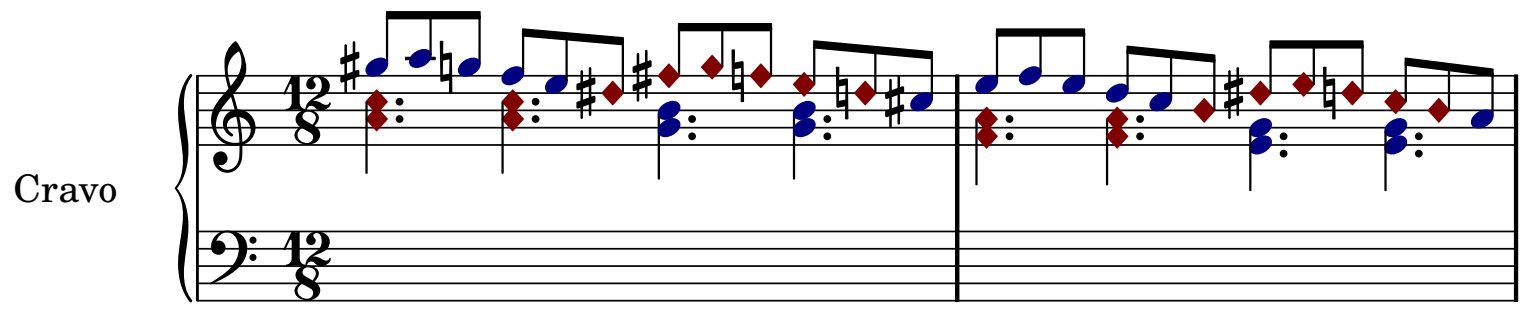

Figura 5.4: Compassos 5 e 6 da Sonata K.54 (edição de John Sankey)

Ainda que as indicações presentes na partitura historicamente orientada sejam um erro de interpretação de John Sankey, podemos notar que o gesto físico contribui en- 
quanto componente morfológico musicalmente significativo a ponto de ser claramente perceptível e haver uma preocupação criteriosa a esse respeito. E mesmo que alguém objete que tais mudanças gestuais não interfiram no resultado sonoro, as mudanças físicas do gesto, em si mesmas, são claramente componentes da expressão musical.

\subsection{Frédéric Chopin}

O pianista e compositor polonês Frédéric Chopin determina certos gestos físicos de modo muito preciso e com uma forte intenção musical, como sugere Charles Rosen; porém muitas vezes tais indicações não são seguidas pelos intérpretes. Segundo Rosen (Rosen 1998, p.365) ${ }^{3}$ dois desses gestos altamente idiossincráticos sugeridos pelos dedilhados são as passagens que utilizam somente os dedos:

- 5 ;

- 4 e 5 ;

- 3,4 e 5 .

Isso é confirmado pela citação que Robert Schumann faz de um desses gestos idiossincráticos de Chopin, no movimento Chopin da obra Carnaval op.9 para piano [figura 5.5]. O segundo gesto idiossincrático sugerido pelos dedilhados refere-se às passagens somente com o polegar, que ocorrem, por exemplo, no Concerto para Piano em Fá menor, e na Balada op. $52 \mathrm{n}^{\mathrm{O}} 4$.

3 "Chopin's two most idiosyncratic fingerings are oddly similar: the first is the realisation of a delicate chromatic line entirely with the fourth and fifth fingers (or with the third, forth, and fifth in more complicated passages); the second is the playing of a series of melodic notes entirely with the thumb." 


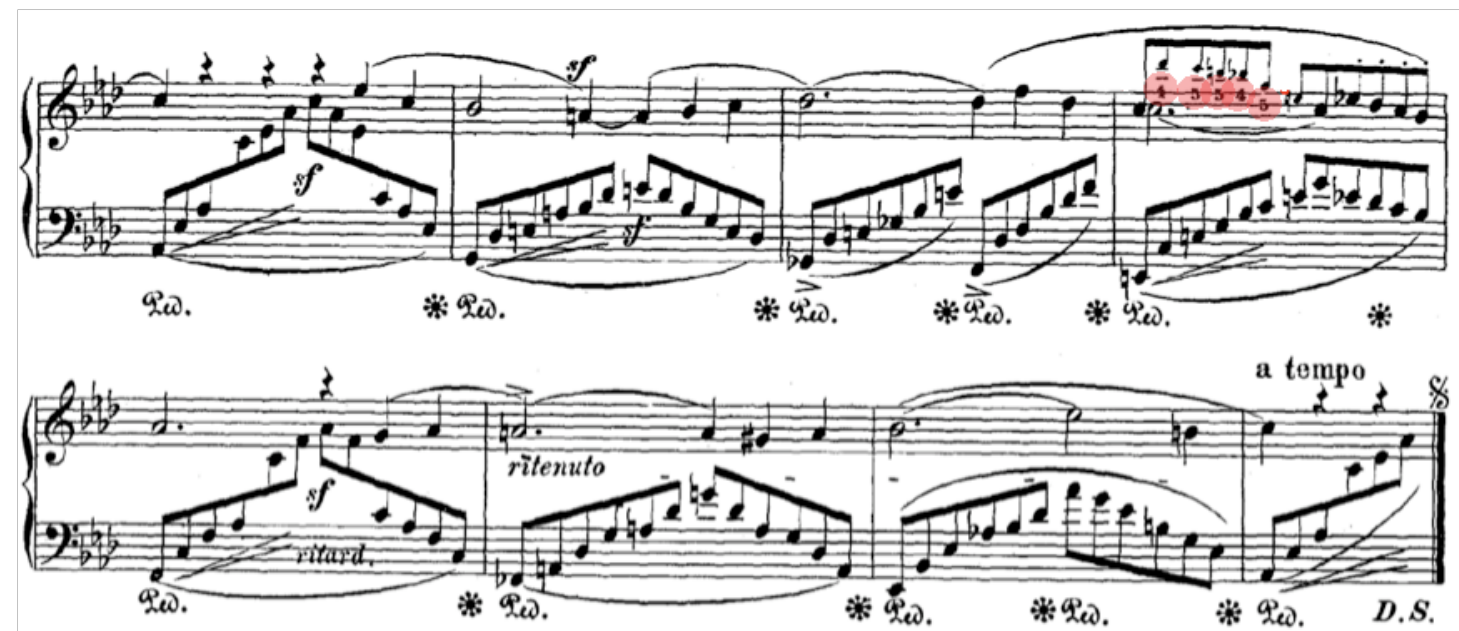

Figura 5.5: trecho do movimento Chopin de Carnaval op.9 de Robert Schumann

Note a citação realizada por Schumann do gesto idiossincrático de Chopin no dedilhado $[4,5,5,4,5,4]$, referente ao uso de tal tipo de gesto em muitas obras como, por exemplo, o Noturno op.9 nº2 (figura 5.6.

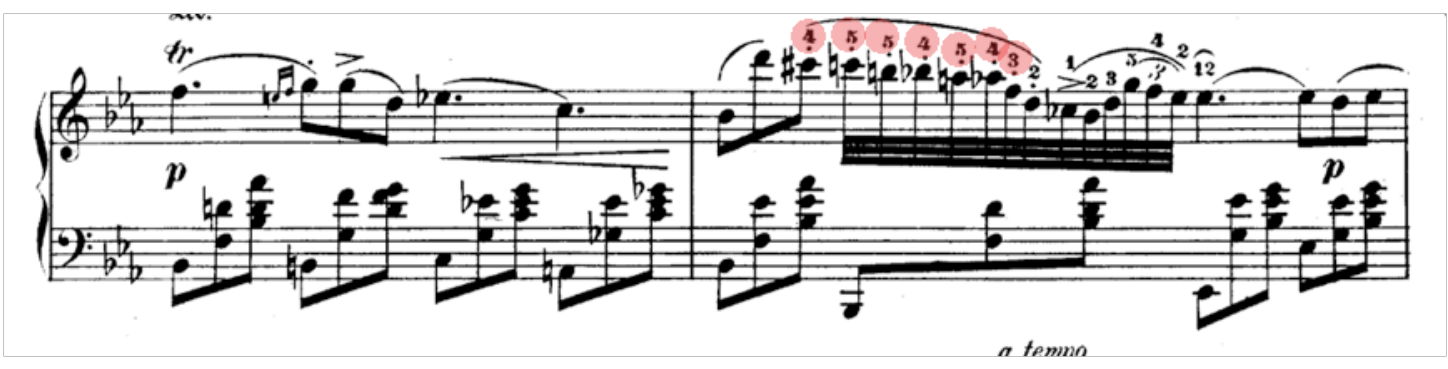

Figura 5.6: trecho do Noturno op.9 №2 de Chopin. Note o dedilhado 4-5-5-4-5-4.

O seu uso do quinto dedo e do polegar colocam Chopin em uma direção oposta à prática reinante no ensino do piano, no qual possui como ideal fazer com que todos os dedos sejam igualmente fortes. Chopin insistiu que cada dedo era fundamentalmente diferente em caráter, e que o intérprete deveria tentar explorar essas diferenças. (Rosen 1998, p.368) ${ }^{4}$

\footnotetext{
4"His use of fifth finger and thumb put Chopin in direct opposition to the reigning contemporary piano pedagogy, the ideal of which was to make all fingers equally powerful and nimble. Chopin insisted that each finger was fundamentally different in character, and that the performer should try to exploit that difference. His use of the fourth and fifth fingers for delicate chromatic effects became almost a trademark."
} 
Nos Estudos op.10 e op.25 as limitações físicas impostas são mais evidentes, justamente por serem estudos de técnica. "Seu interesse musical é derivado de uma dificuldade técnica específica" (ㅈosen 1998). É evidente que ele se preocupou mais com as qualidades estéticas autônomas de tais obras do que com suas funções de exercícios de técnica. A obra não existe somente para exercitar uma dificuldade, mas ocorre justamente o contrário: "a mão, com seu arranjo de músculos e tendões, seu formato idiossincrático" (ํㅗㄹ 1998) é que serve de estímulo e inspiração criativa à expressão musical. Chopin dava muita atenção às suas indicações de dedilhado, como podemos constatar quando afirma $5^{5}$ que cada dedo tem suas propriedades expressivas, e "há muitas qualidades de som" para diferentes dedilhados, "a questão é [saber] usar tais diferenças" no contexto musical (ver figura 5.7).

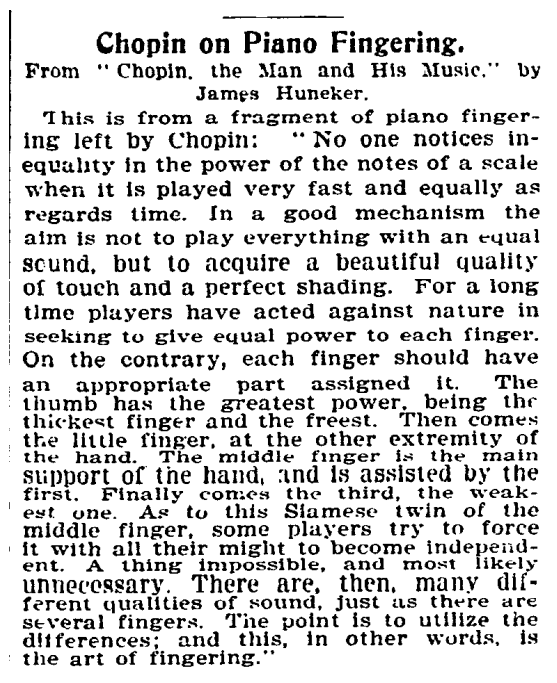

Ehe Äew Jork Ëimes

Published: March 24, 1901 Copyright $\odot$ The New York Times

Figura 5.7: Nota em jornal atribuída a Chopin. Ver nota de rodapé 5.

Rosen aborda ainda o uso característico de conformações da mão na obra pianística de Johannes Brahms. O Scherzo da Grand Sonata op.11 nº 1 de Robert Schumann (1810-1856), pode ser outro caso digno de menção neste contexto: o autor determina o

\footnotetext{
${ }^{5}$ Nota publicada no New York Times em 24 de Março de 1901. Disponível em http://query. nytimes. com/mem/archive-free/pdf?res=9903E4D71330E132A25757C2A9659C946097D6CF. Acesso 10 jan. 2009.
} 
dedilhado $[2,1,2,1,2,1,2]$ e com um propósito musical e expressivo preciso (figura 5.8)..$^{6}$

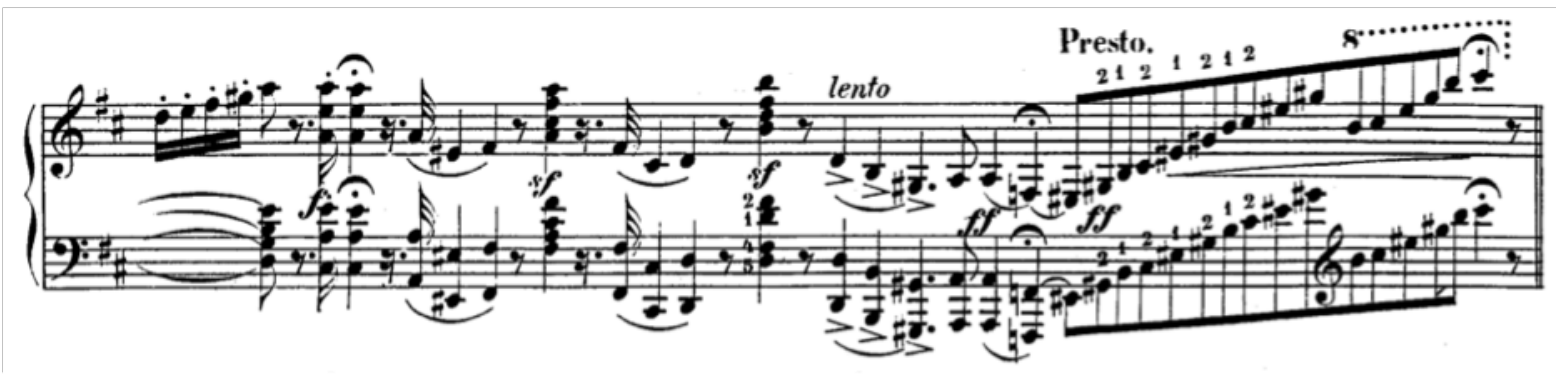

Figura 5.8: Sonata №1 Op.11 de Robert Schumann

\subsection{Michael Finnissy}

O compositor e pianista Michael Finnissy, nascido em Londres no ano de 1946, também nos proporciona exemplos interessantes sobre a questão da fisicalidade em instrumentos de teclado. Utilizaremos excertos de sua obra Alkan-Paganini (1997), parte do ciclo para piano The History of Photography in Sound 7. Tal movimento é dividido em duas partes (em referência aos dois compositores do título): na seção Alkan (figura 5.9p o compositor determina que somente a mão esquerda deve ser utilizada; já em Paganini (figura 5.10), somente a mão direita.

\footnotetext{
6"No one notices inequality in the power of the notes of a scale when it is played very fast and equally as regards time. In a good mechanism the aim is not to play everything with an equal sound, but to acquite a beautiful quality of touch and a perfect shading. For a long time players have acted against nature in seeking to give equal power to each finger. On the contrary, each finger should have an appropriate part assigned it. The thumb has the greatest power being the thickest finger and the freest. Then comes the little finger, at the other extremity of the hand. The middle finger is the main support of the hand and is assisted by the first. Finally comes the third, the weakest one. As to this siamese twin of the middle finger, some players try to force it with all their might to become independent. A thing impossible, and most likely unnecessary. There are, then, many different qualities of sound, just as there are seceral fingers. The point is to utilize the differences: and this, in other words, is the art of fingering." (Atribuido a Chopin, publicado por James Huneker no periódico 'The New York Times' em 24 de Março de 1901. Disponível em http://query.nytimes. com/mem/archive-free/pdf?res=9903E4D71330E132A25757C2A9659C946097D6CF Acesso 10 jan. 2009.)
}

${ }^{7}$ FINISSY. M. Alkan-Paganini (1997), The History of Photography in Sound. Oxford Music Press. 


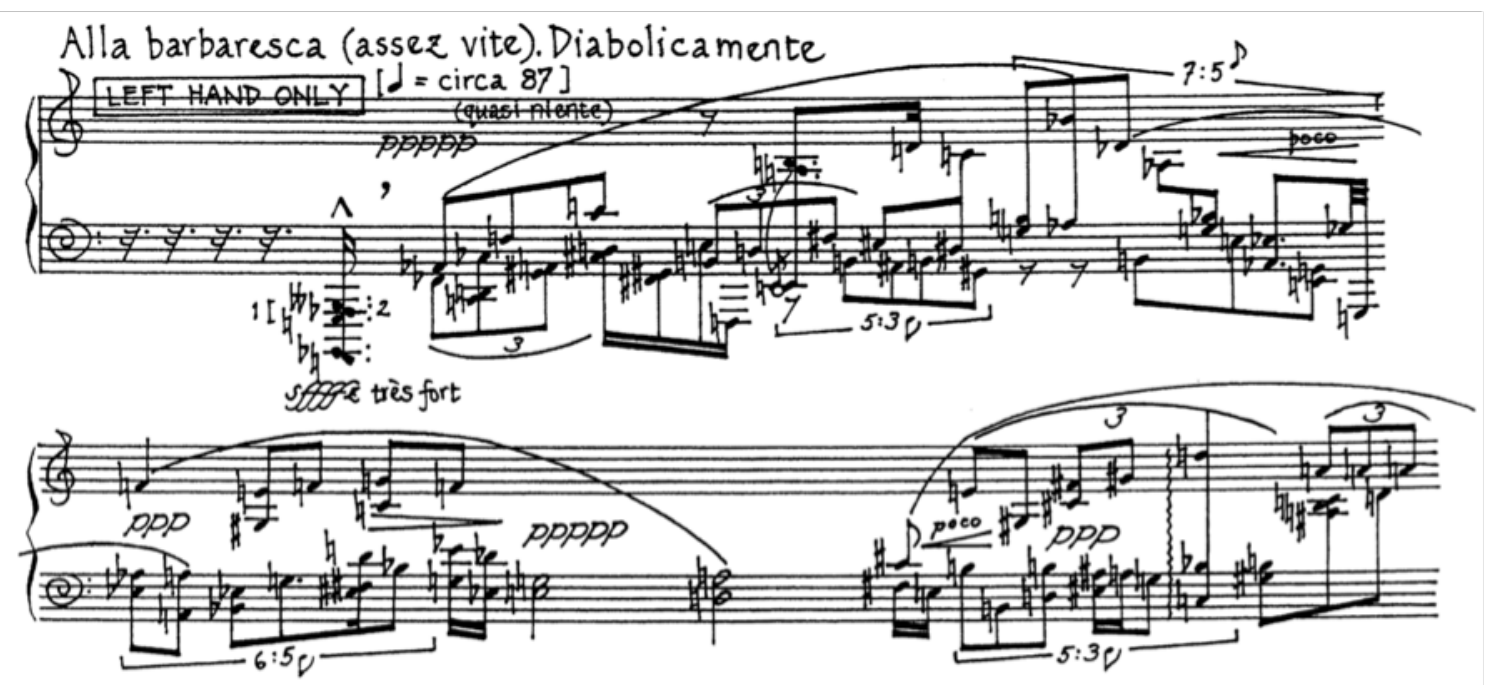

Figura 5.9: Início de Alkan-Paganini (1997) de Michael Finnissy

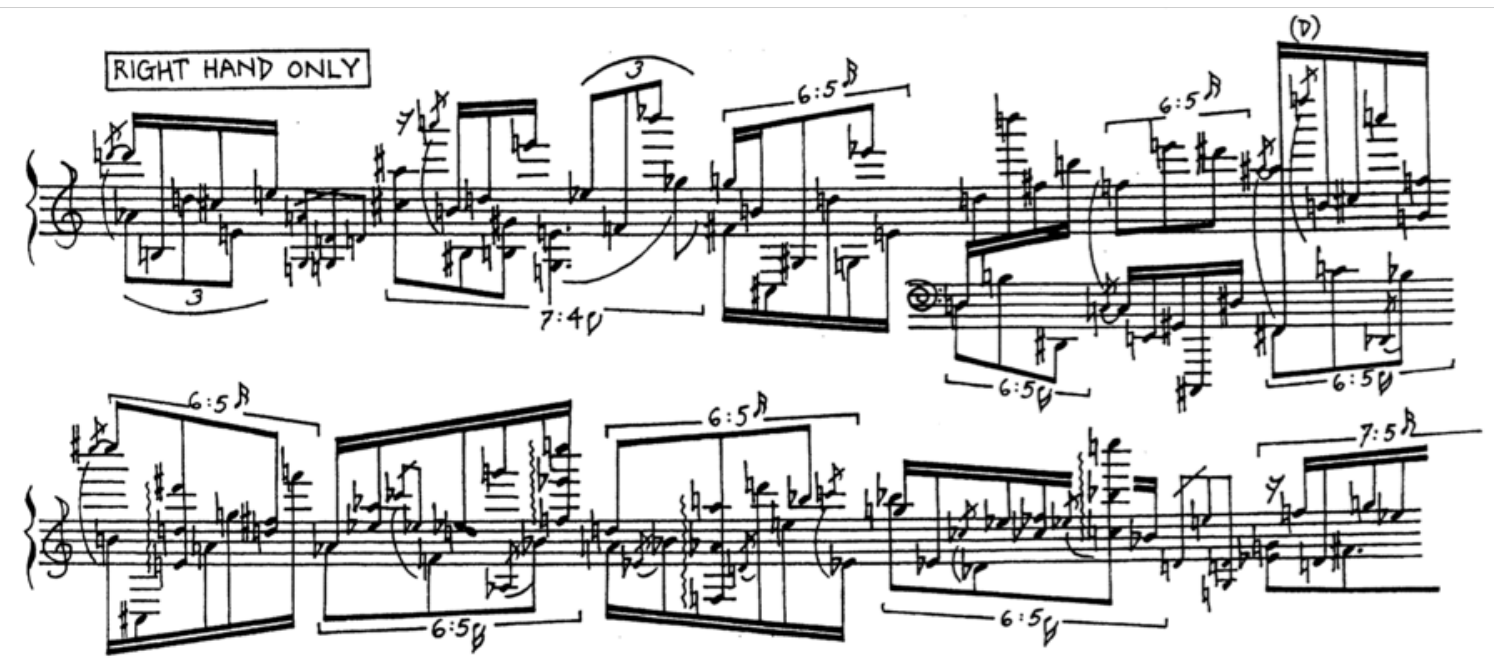

Figura 5.10: Início da segunda parte de Alkan-Paganini (1997) de Michael Finnissy

A primeira seção é referente a uma transcrição de Jeanne qui pleure et Jean qui rit realizada por Alkan, por sua vez recompondo Offenbach. Já a segunda seção refere-se ao Capriccio op.1 nº12 de Paganini, também transcrito por Schumann (op.10, nº1). O fato de Michael Finnissy delimitar o uso de apenas uma das mãos num trecho de difícil execução (onde seria perfeitamente possível utilizar as duas mãos), demonstra as intenções do compositor no que se refere à técnica pianística, na relação corporal com o instrumento e também a um fator histórico. No aspecto da técnica pianística e da relação corporal com o instrumento é criada uma tensão tanto para o intérprete quanto 
para o ouvinte, que percebe a "dificuldade de executar o trecho da obra com apenas uma das mãos, tornando o virtuosismo mais um componente musical, que se soma às alturas, durações, dinâmicas etc. O fator histórico presente na obra de Finnissy também vem no sentido de embasar a questão da corporalidade, considerando especialmente a relação dos compositores Alkan e Paganini com seus respectivos instrumentos. A relação de Alkan com o piano, tanto como compositor quanto como pianista, é pontuada especialmente pelo virtuosismo. O mesmo ocorre com Paganini, que enquanto violinista e compositor também é reconhecido pelo tratamento virtuosístico de seu instrumento. Na obra de Finnissy podemos perceber o quão influente é a questão da corporalidade, tanto no aspecto da pesquisa sobre o virtuosismo no século XIX (citando Alkan e Paganini) quanto em sua pesquisa pessoal a cerca dos limites da técnica pianística relacionada à fisicalidade do gesto musical e da tensão advinda destes limites, que gera um novo componente formal para a composição.

\subsection{Anton Webern}

Nesta seção tentaremos demonstrar a importância do gesto físico e da corporalidade na construção, composição e interpretação das Variações op.27 de Anton Webern. Nossa hipótese é que a própria construção da série e elementos tidos como abstratos estão, segundo nossa hipótese, a serviço de um argumento físico e corporal fundamental.

As Variações constituem um caso elucidativo sobre a função do gesto físico como agente significativo em um argumento musical, especialmente porque este compositor é, mais que comumente, considerado unilateralmente pelo viés dos parâmetros "primários $\sqrt{8}$ em detrimento de outros aspectos, como no exemplo desta obra, a corporalidade. As análises em geral concentram-se quase que exclusivamente nos parâmetros "primários (classe de altura, duração, instrumentação e dinâmica). Os desafios de nossa leitura - um pouco diferente da "análise musical tradicional" e dos "métodos redutivos da prática tradicional" (Adorno 2002, p.174) - será o de não se limitar aos chamados de

\footnotetext{
${ }^{8}$ Sobre parâmetros "primários"e "secundários" ver seção 4.2 .
} 
parâmetros "primários" e aos elementos identificáveis na notação musical, pois assim corre-se o risco de subordinar ou ignorar importantes elementos morfológicos nos jogos da composição musical.

O fato do gesto físico e a corporalidade serem portadores de conteúdo musicalmente significativo nas Variações op.27 é evidente, tanto que nos arriscaríamos a supor que este foi um importante componente gerador de forma e articulação no processo de composição, incluindo a escolha da série e suas manipulações. Aqui partiremos dos elementos menores, as alturas e os ritmos, para em seguida investigar a estruturalidade destas escolhas em relação à corporalidade em jogo em uma tentativa de revelar o "conceito de material" em funcionamento na obra. Isso incluiria o procedimento de composição, as decisões em cada passo deste processo e seus propósitos, além das relações entre todos as interconectividades entre os componentes do argumento musical. Como Adorno aponta a respeito da análise musical:

E correspondentemente, se alguém parte dos elementos constituintes como ponto de partida, a tarefa será entender como esses elementos, em si mesmos, e frequentemente em contradição entre si, e através desta contradição, também simultaneamente gera o todo. [...] Análise é sempre um processo duplo. [...] se alguém não ouve a própria tendência direcional contida em cada um dos elementos, então pode-se dizer que a descrição dos momentos individuais já, por este mesmo motivo, perdeu o sentido. (Adorno 2002, p.174-175) 9

A noção de uma "visão" composicional foi descrita por inúmeros compositores ao longo dos registros históricos, mesmo aqueles tidos como abstratos ou racionais, anterior

9"And correspondingly, if one takes the elements as the point of departure one's task is to understand how these elements in themselves, and frequently in contraiction to each other, and then through this contradiction, also simultaneously generate the whole. In this sense - that is, relative to whole and to part - analysis is always a double process. [...] Take, for example, the well-known counter-

subject to the first theme of Mahler's Fourth Symphony: Already, right from the very beginning, one has to listen to this in terms of the direction it wants to go and for which it yearns, in terms of the fact that it is striving untimately beyond itself toward the high $\mathrm{B}$, in order to fulfill itself; and if one doesn't hear this in its individual elements, if one doesn't hear the theme's own directional tendency within each single element, then the description of the individual moments can already, for the very reason, be said to have missed the point." 
a qualquer procedimento de construção.

Naturalmente tal aparato técnico (utilizar um computador para auxiliar nos frequentemente complexos - cálculos) só pode obter significância no contexto de uma 'visão' composiciona

Ou Stockhausen ao rebater a afirmação de que "há várias fases em seu trabalho no qual a música tem um caráter fortemente objetivo":

Isto não é verdade. Eu sempre senti a música como uma visão, e eu só me interesso por uma nova peça se eu tiver ouvido e visto algo - internamente que fora completamente novo e fascinante para mim; e então se segue um processo mental de construção, e assim continua sendo hoje. Este processo mental de construção é um processo de copiar a minha imaginação o mais perfeitamente possível, ou pode-se dizer que é a redução da minha imaginação para os meios, para o mundo instrumental, que agora existe, o que, na sua maior parte, devo até mesmo expandir de modos inesperados, de forma a aproximar-se de alguma forma ao que imaginei no início. 11

Partiremos da escolha da série e suas transformações: o motivo que levou o compositor a escolher essa série e essas manipulações. Uma questão surge: ele parte de uma série concebida abstratamente ou a partir de uma visão que incluiria uma "corporalidade inteligente" (Cox 2003)? Como podemos investigar as relações entre tais componentes e sua presença e relacionamento no processo de composição? Eis o eixo principal da

10 "Naturally, such a technical apparatus (using a computer to assist in the often complex calculations) can only achieve significance in the context of some kind of compositional "vision'". BARRETT, R. Nota de programa de Cö̈itum (1983-85). Disponível em http://www.ump.co.uk/Barrett/ rb-coigitum.htm. Acesso em 10 de maio de 2009.

11 "That is not correct. I have always felt music, primarily with each new work, as a vision, and I have only been interested in a new piece, if I have heard and seen something - inwardly - that was completely new and fascinating for me, and then a mental process of construction followed, and that is the same today. This mental process of construction is a process of copying my imagination as flawlessly as possible, or one could say the reduction of my imagination to the means, to the instrumental world, that now exists, which, for the most part, I must even completely unexpectedly expand, in order to somehow come closer to what I imagine. ." (Stockhausen, K. Stockhausen's World Theatre. Disponível em http://www.stockhausen.org/stockhausens_world_theatre.pdf. Acesso em 10 de maio de 2009.) 
análise, poderíamos aqui adiantar algumas considerações da nossa leitura: a energia necessária para realizar cada gesto; a relação de correspondência ou contradição entre o gesto físico (sua ação, energia e intenção) e o resultado acústico; a expectativa gerada por um gesto ou uma sequência de gestos; a estruturalidade de cada gesto, por exemplo suas funções de tensão ou relaxamento na experiência musical, ou o grau de concordância ou contradição contido no interior do gesto.

Em tal processo de resgate do processo composicional, ou de especulação das raízes do material, tentaremos revelar tal 'visão' e como ela guiou as escolhas composicionais do compositor. A que essa visão está ligada? A uma relação abstrata de intervalos ou a gestos concretos? Esta série estaria construída a partir desta visão ou constitui um processo paralelo e independente? Como a série, as escolhas e alocações de suas formas são decorrência da visão primordial da música? Como nasce a série?

Como nasce a série? Ela não é fruto do acaso nem do arbitrário, mas organizada a partir de certas reflexões. Nos propomos determinadas questões formais. [...] Nossas séries - as de Schönberg, Berg e minhas [Webern] - são na sua maioria o resultado de uma ideia relacionada a uma visão intuitiva da obra concebida como um todo; em seguida, essa ideia foi submetida a uma reflexão cuidadosa [...]. É a inspiração, se vocês quiserem. (Webern 1984, p.145-6)

A série constitui um campo de possibilidades e uma tendência escolhida criteriosamente para ser exposta aos campos magnéticos, à ação de vetores, distorções e energias expressivas. Sob o nosso ponto de vista o que nessa peça determinou a escolha da série e de suas manipulações foi (nos termos de Cox) uma corporalidade inteligente. Frank Cox tentou definir com a expressão "corporalidade inteligente" (Cox 2003) 2 potenciais construtivos na composição musical que levem em consideração a corporalidade, as potencialidades dessas inter-relações de "novas sortes de polifonias corporais". Não um stratum subordinado a todo os outros parâmetros, porém um dos agentes funcionais em

\footnotetext{
${ }^{12}$ Cox, F. Toward an intelligent corporality: The virtual body. In: Manhkopf, C.; Pagh-PaAn, Y.
} (Ed.). ars (in)humana? Bremem: Einwurf, 2003. 
jogo. No caso da nossa pesquisa, que se concentra no gesto físico e na corporalidade, há também a preocupação de não se abandonar todas as conquistas estruturais, de planejamento, de sistematização, de racionalização da música do século XX. Ou seja, não rebaixar a racionalidade, mas antes elevar em alguns degraus as possibilidades da corporalidade. Eis também um dos motivos de se ter escolhido um compositor como Anton Webern, já que este possui um conceito de material tão radicalmente inovador e ao mesmo tempo tão concentrado em relações de altura e de motivos. Porém mesmo aí a corporalidade também participa de seu argumento musical. Na tabela 5.1 podemos encontrar as possibilidades intervalares da série, o que nos dá as seguintes possibilidades de trajetórias na matriz de possibilidades de classes de alturas, representados na tabela 5.2 . A matriz representada na tabela 5.2 corresponde a todas as possibilidades de transposição, inversão e retrogradação da série original.

\begin{tabular}{|c|c|c|c|c|c|c|c|c|c|c|c|}
\hline ORIGINAL & $2 \mathrm{~m} \uparrow$ & $3 \mathrm{M} \downarrow$ & $2 \mathrm{M} \uparrow$ & $3 \mathrm{~m} \downarrow$ & $2 \mathrm{M} \uparrow$ & trítono & $2 \mathrm{~m} \uparrow$ & $2 \mathrm{~m} \uparrow$ & $3 \mathrm{M} \downarrow$ & $2 \mathrm{~m} \uparrow$ & $3 \mathrm{M} \uparrow$ \\
\hline INVERSÃO & $2 \mathrm{~m} \downarrow$ & $3 \mathrm{M} \uparrow$ & $2 \mathrm{M} \downarrow$ & $3 \mathrm{~m} \uparrow$ & $2 \mathrm{M} \downarrow$ & trítono & $2 \mathrm{~m} \downarrow$ & $2 \mathrm{~m} \downarrow$ & $3 \mathrm{M} \uparrow$ & $2 \mathrm{~m} \downarrow$ & $3 \mathrm{M} \downarrow$ \\
\hline RETRÓGRADO DA INVERSÃO & $3 \mathrm{M} \uparrow$ & $2 \mathrm{~m} \uparrow$ & $3 \mathrm{M} \downarrow$ & $2 \mathrm{~m} \uparrow$ & $2 \mathrm{~m} \uparrow$ & trítono & $2 \mathrm{M} \uparrow$ & $3 \mathrm{~m} \downarrow$ & $2 \mathrm{M} \uparrow$ & $3 \mathrm{M} \downarrow$ & $2 \mathrm{~m} \uparrow$ \\
\hline RETRÓGRADO & $3 \mathrm{M} \downarrow$ & $2 \mathrm{~m} \downarrow$ & $3 \mathrm{M} \uparrow$ & $2 \mathrm{~m} \downarrow$ & $2 \mathrm{~m} \downarrow$ & trítono & $2 \mathrm{M} \downarrow$ & $3 \mathrm{~m} \uparrow$ & $2 \mathrm{M} \downarrow$ & $3 \mathrm{M} \uparrow$ & $2 \mathrm{~m} \downarrow$ \\
\hline
\end{tabular}

Tabela 5.1: Intervalos das Variações Op.27 de Webern 


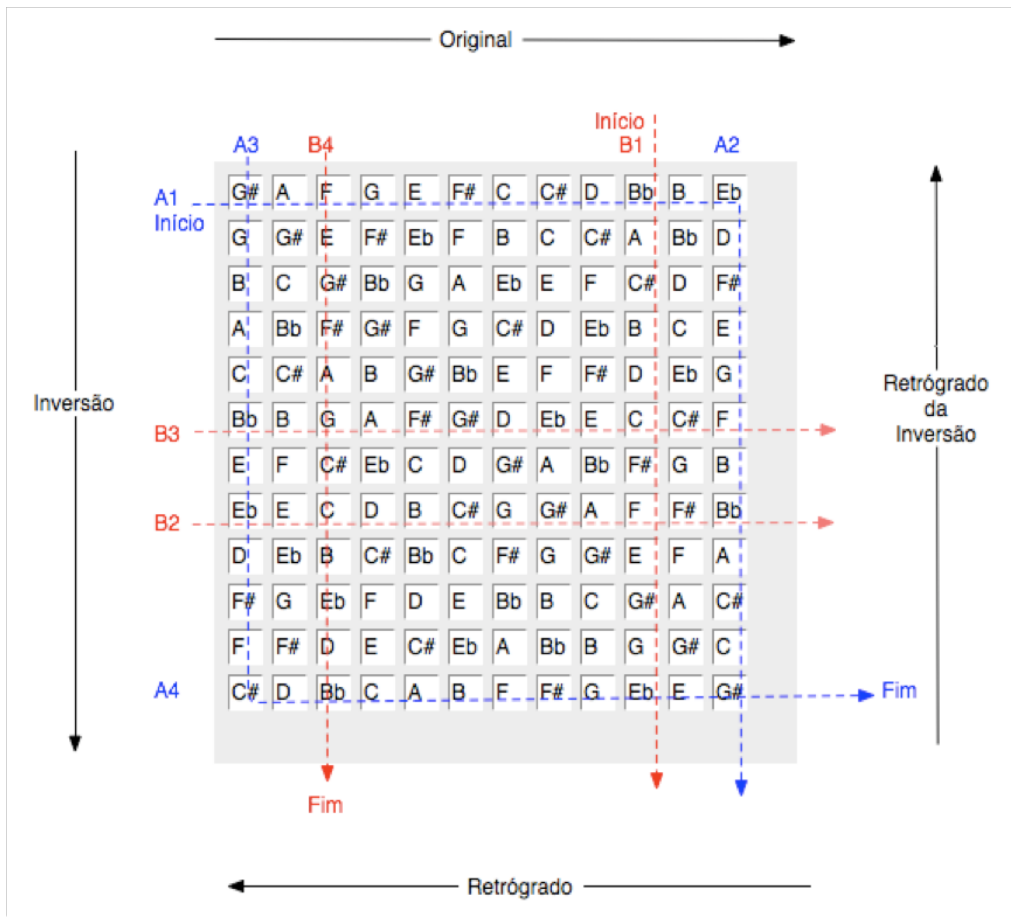

Tabela 5.2: Trajetórias da série original e séries derivadas.

Algo importante de se observar sobre o que provavelmente determinou a escolha da série com suas possibilidades e suas alocações: as alturas são agrupadas sempre aos pares, em alternância e com a mesma duração - como inscrita na notação (duas colcheias em andamento muito rápido). Também acontecem formações de dois grupos de duas notas (como as acciaccature, que aparecem seis vezes), ou como dois grupos de três notas (ou acordes, quatro vezes). Na maioria desses momentos ocorre pausa de colcheia (vinte e uma vezes) entre eventos. Também pode não ocorrer a pausa (sete vezes), ou ocorrer uma pausa de duas colcheias (uma vez), ou uma pausa de quatro colcheias (um vez); o que faz desses momentos de exceção articulações importantes no todo. Podemos considerar a peça tanto um cânone a duas vozes, que se alternam ritmicamente de duas em duas notas ou acordes, quanto uma sequência de gestos cada qual com sua dinâmica, com uma ação separada para cada mão, logo, uma dupla trajetória espacial de movimento. A série e suas manipulações escolhidas foram pensadas de modo que esses pares se limitassem sempre a um grupo bem restrito de intervalos, e esses intervalos, por sua vez, se restringem a tipos de gestos específicos para tais intervalos, porém sempre 
em uma ordem diferente. Ou seja, uma das funções da série e suas manipulações é a permutação dos gestos de acordo com um método sistemático. Observando a partitura podemos constituir as trajetórias que o compositor escolheu dentre as possibilidades dadas pela matriz de possibilidades. Note que uma voz será sempre a inversão da outra, quando uma seguir uma trajetória horizontal a outra seguirá uma trajetória vertical e vice-versa (figura 5.11).

A1

Sehr schnell $\bullet=$ ca 160
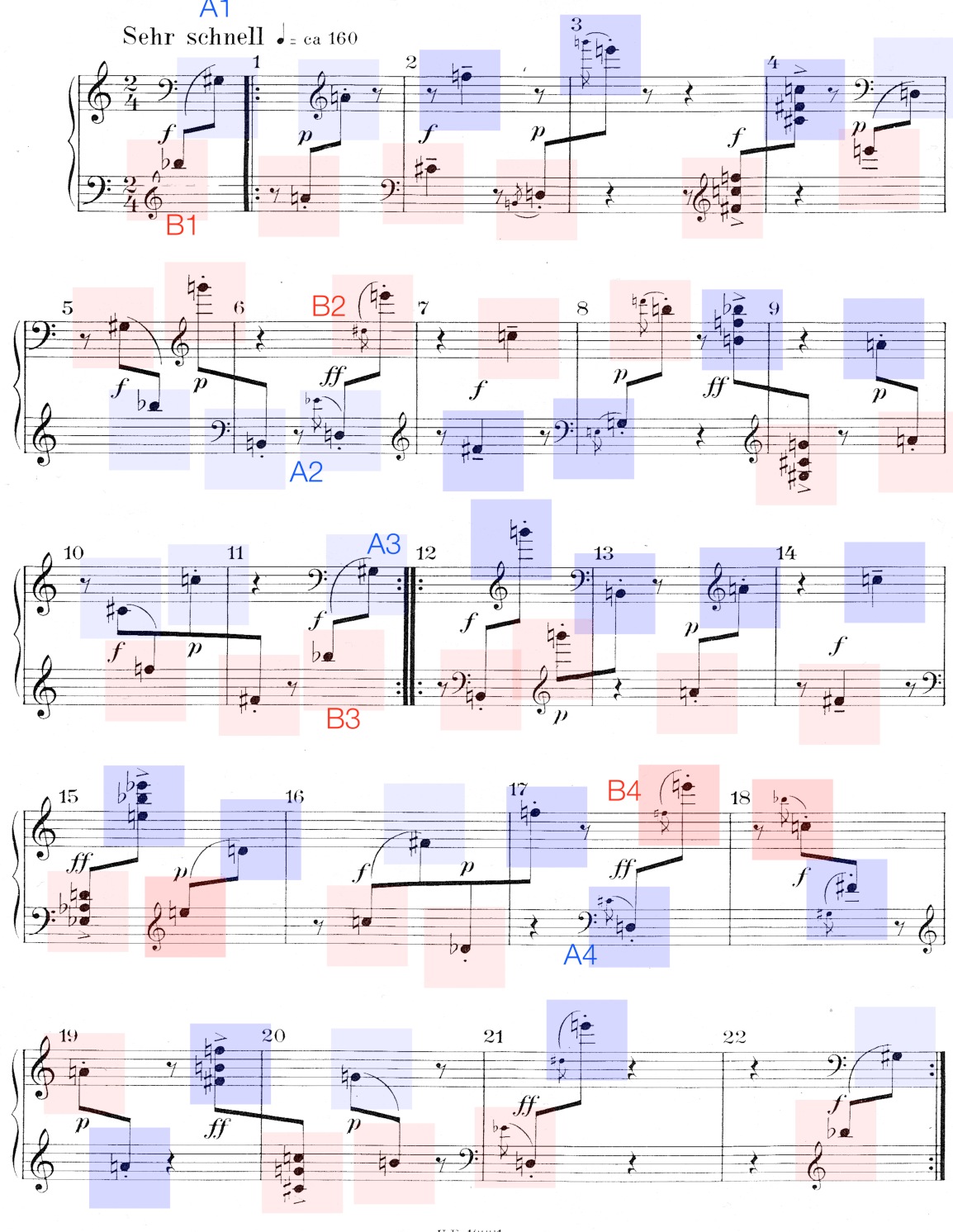

Figura 5.11: Variações op.27 Movimento II de Anton Webern

Percebe-se que além disso a escolha do registro ocorre de tal modo que os intervalos 
estão sempre em simetria em relação à nota lá (acima do dó central), como também o registro das alturas dos gestos é congelado. Com três exceções, onde mesmo com a simetria em relação ao lá central, há alguma mobilidade entre registros (figura 5.12 e 5.13 ):

- o mi bemol ocorre sempre um trítono acima e abaixo em relação ao lá central, ou um décima segunda diminuta acima e abaixo do mesmo lá;

- os pares de classes de altura ré e mi, em três combinações simétricas;

- o par sol e si, que podem ocorrer em três oitavas, em três combinações simétricas.

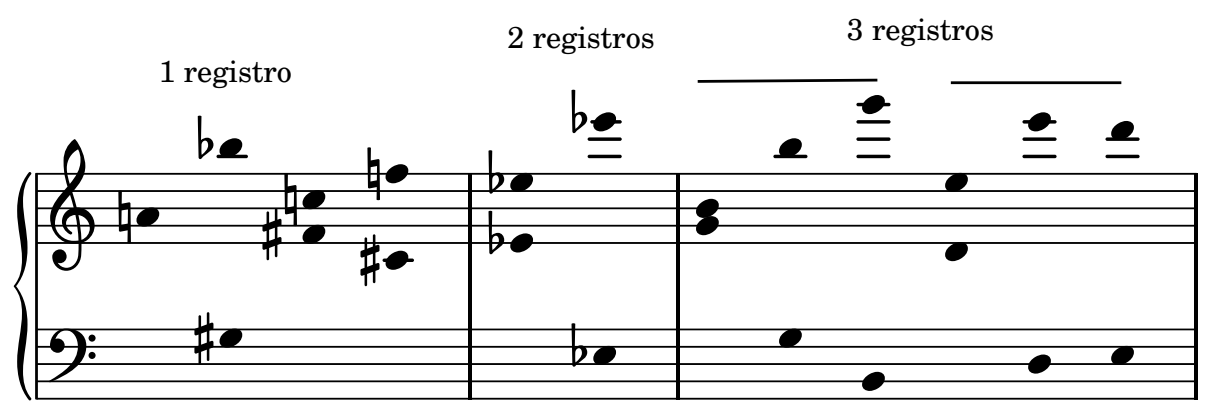

Figura 5.12: Alturas fixadas em registros

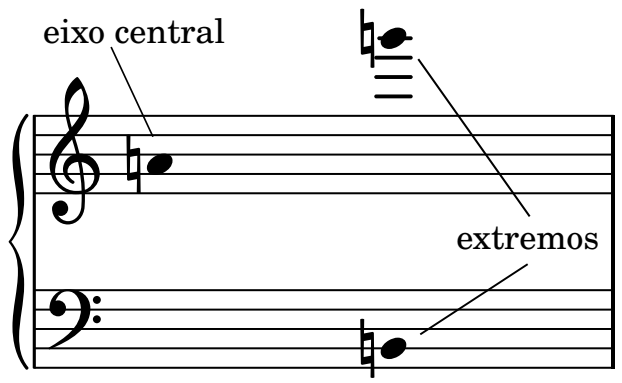

Figura 5.13: eixo de simetria $\leftarrow\left[l \hat{a}^{\prime}\right] ;$ extremos agudo e grave $\leftarrow\left[\right.$ si, sol $\left.^{\prime \prime \prime}\right]$

Podemos supor alguns dos motivos que determinaram essas escolhas. Uma vez que as duas vozes do cânone em inversão estão sempre em alternância, podemos adicionar alguns motivos a mais para a escolha da série. Ela é escolhida de modo que:

- algumas alturas importantes coincidam em momentos-chave da peça;

- a última nota de cada transformação coincida com a primeira nota da próxima sequência; 
- ou a primeira ou a última nota de cada sequência sejam iguais, o que acarreta a repetição dos mesmos intervalos permutados entre as sequências (ver figura 5.14).
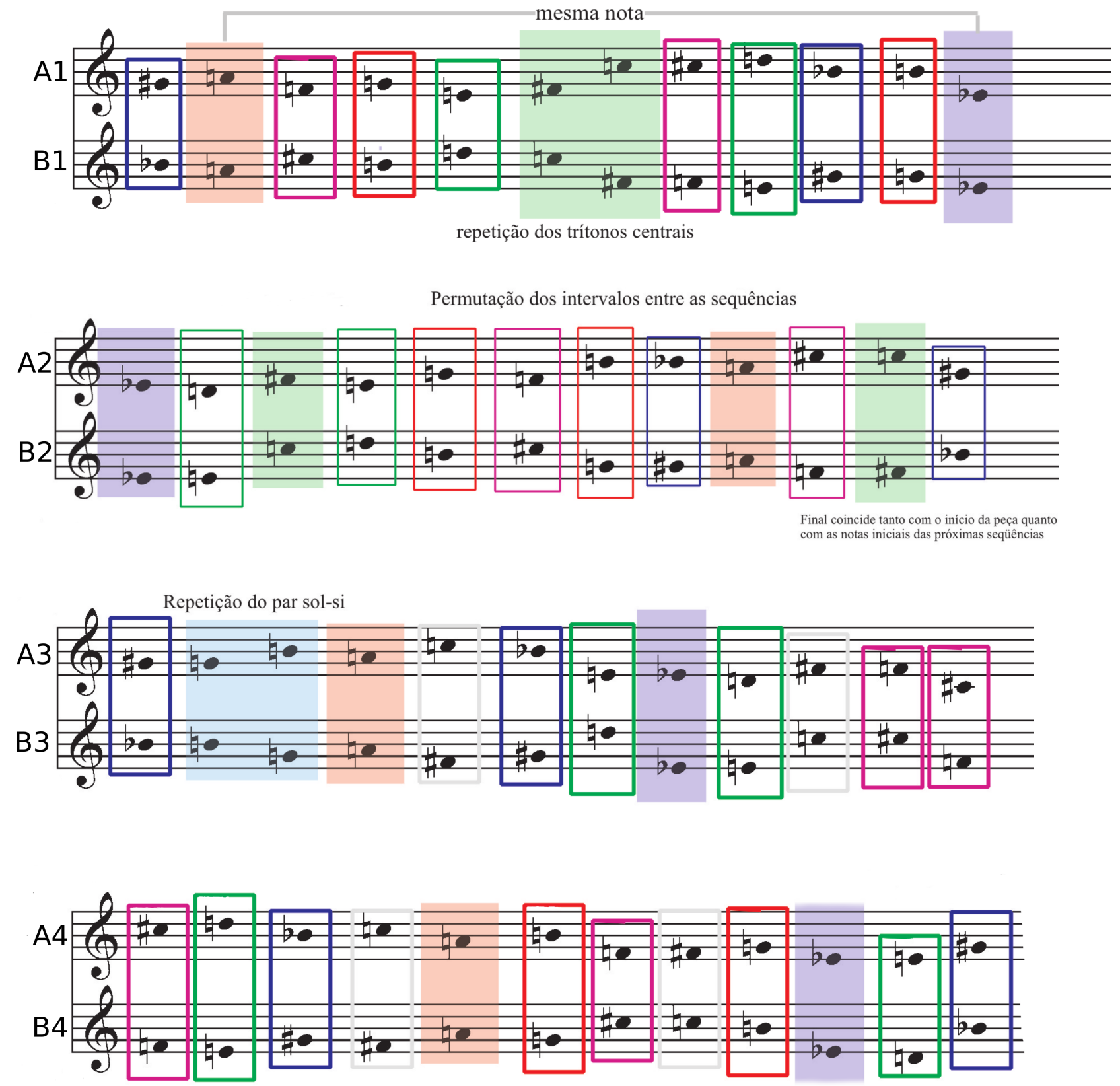

Figura 5.14: Esquema geral das manipulações da série original

Um momento se mostra como um eixo estrutural importante na peça: o par $\left[\begin{array}{ll}\text { sol }^{\prime \prime \prime} & s i,\end{array}\right]$, repetido duas vezes com alternância de mãos $13\left[\begin{array}{llll}s i, m . e . & s o l_{m . d .}^{\prime \prime \prime} & s o l_{m . e .}^{\prime \prime \prime} & s i,{ }_{m . d .}\end{array}\right]$, nos ${ }^{13}$ Indicado por m.e. (mão esquerda) e m.d. (mão direita). 
seus registros extremos, com o gesto que requer mais energia na peça, e com uma contradição entre essa energia e a dinâmica pedida no interior desse gesto, assim como a contradição entre este gestos e seus gestos vizinhos (figura 5.15).

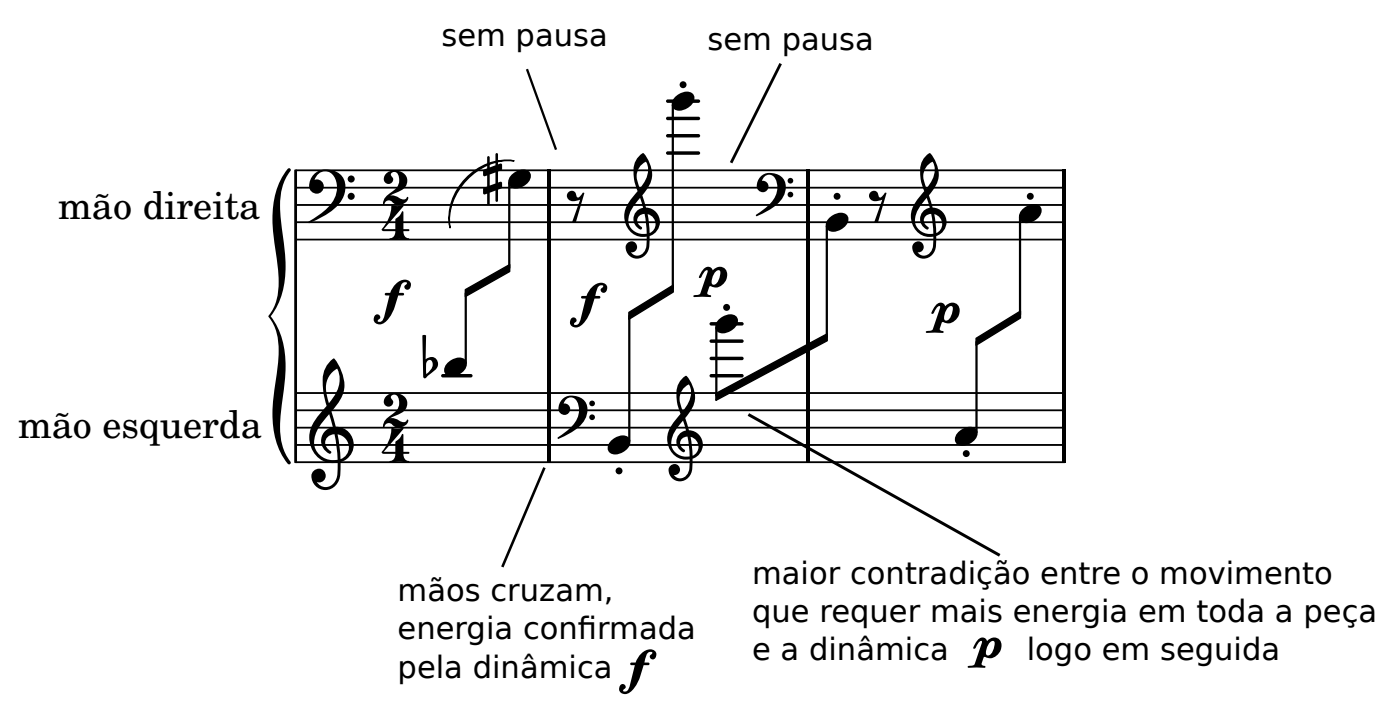

Figura 5.15: Gesto-chave da obra.

Estes gestos centrais (que de fato ocorrem no centro da partitura, como também têm importância central) podem ser considerados o clímax da peça. Muitos intérpretes da obra ignoram as indicações de mãos somente e justamente neste ponto; onde, devido à extrema velocidade de execução, a energia necessária para a realização do gesto é tal que impossibilita a manutenção do andamento (ao nosso entender tal fenômeno é parte integrante da obra e não poderia ser despercebido). Este jogo entre a correspondência ou contradição entre a energia requisitada para a produção do gesto e a dinâmica pedida é elaborada em diferentes graus. Esse jogo entre essas diferentes tensões ou relaxamentos geram um interessante fluxo energético na obra. A energia pedida por um gesto é determinada:

- quando não ocorre a pausa de colcheia (haja vista sua repetição, sua ausência torna-se inesperada) há um aumento considerável da energia;

- quanto maior a distância a ser percorrida no teclado para o cruzamento entre as mãos, maior a energia; 
- quanto mais forte a dinâmica, maior a energia.

A contradição entre essa energia e o resultado sonoro também é um fator importante na articulação e elaboração sintática:

- quando esta corresponde à energia, há uma confirmação da expectativa (maior relaxamento, chamaremos de gesto correspondente);

- quando esta está em contradição à energia, há a negação do esperado (maior tensão, chamaremos de gesto contraditório).

Porém, tais fatores não são rígidos, há uma grande sutileza no jogo entre contradição e correspondência tanto nos gestos em si (as formações locais), quanto na estrutura local entre as formações, quanto também na estrutura do todo. No início da peça, por exemplo, há um cruzamento médio seguido de uma sequência de três gestos que confirmam a expectativa. São, portanto, coerentes na expansão da tessitura do gesto na ordem em que ocorrem.

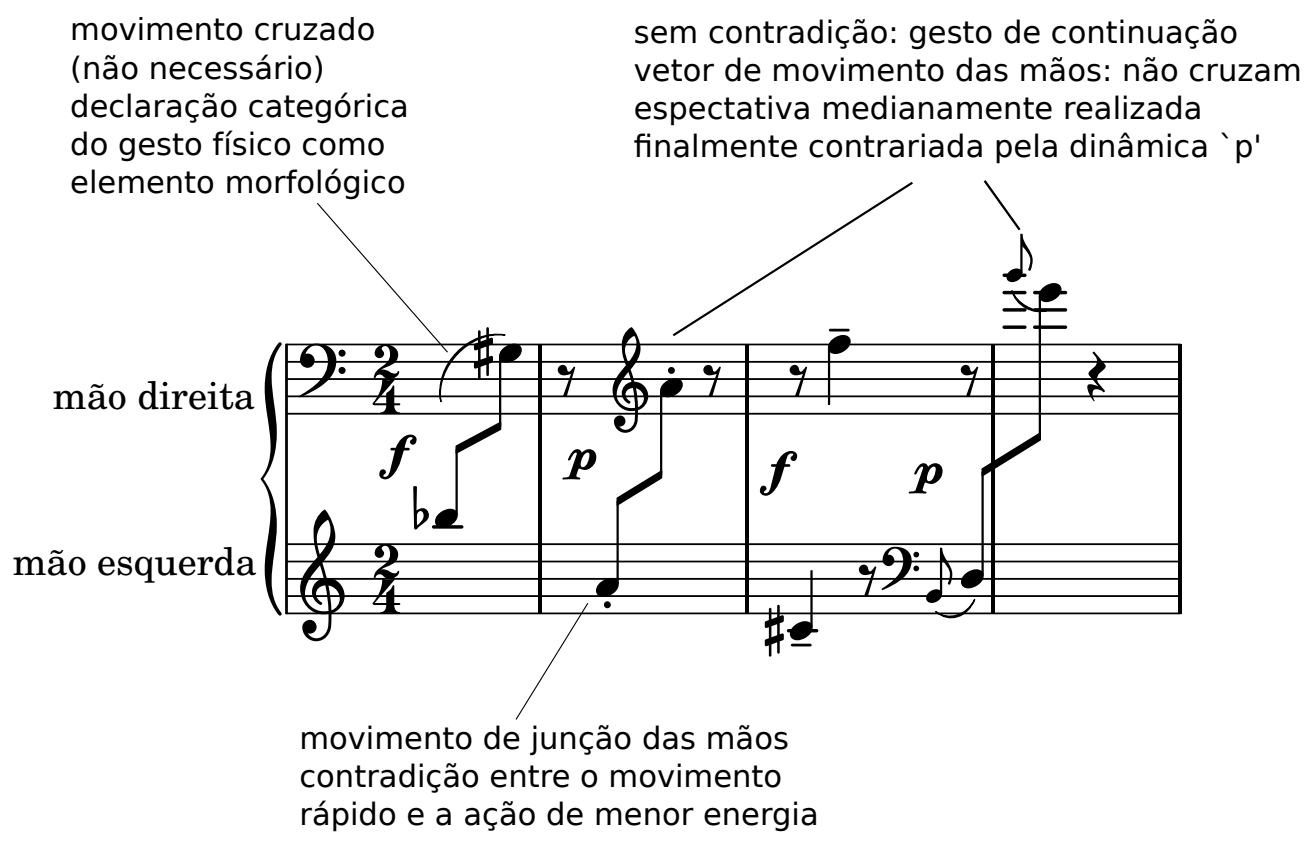

Figura 5.16: Gestos iniciais.

O gesto inicial da obra (figura 5.16) já é uma declaração de que a posição das mãos é 
parte integrante do argumento musical, pois o cruzamento inicial é totalmente desnecessário se tivermos em vista somente as alturas. Durante a obra há uma variada articulação entre direcionalidades simples e previsíveis e movimentos absurdamente abruptos e que requerem toda a energia do intérprete para ser realizado, em especial o gesto sol-si no início da segunda parte da peça. Tendo em vista o andamento pedido, é francamente improvável que o intérprete consiga realizar um movimento tão amplo em tão pouco tempo. Isso inevitavelmente gerará uma tensão essencial para a obra. Além disso tal gesto possui uma contradição interna: justamente quando é prescrita a maior energia possível para o intérprete após uma dinâmica forte, ele deve subitamente ir para a dinâmica piano (figura 5.15).

Ou em outros momentos o cruzamento de mão é mantido, não há nenhum grande deslocamento das mãos, porém a dinâmica prescrita é forte. Logo em seguida a esses momentos, tais gestos são seguidos sem pausa e com um amplo cruzamento de mãos, também com a contradição nas prescrições das dinâmicas, aumentando a tensão (figura 5.17). Ou ainda após um gesto contraditório semelhante, há outro que não pede quase que nenhum movimento das mãos, porém requer uma dinâmica fortissimo.

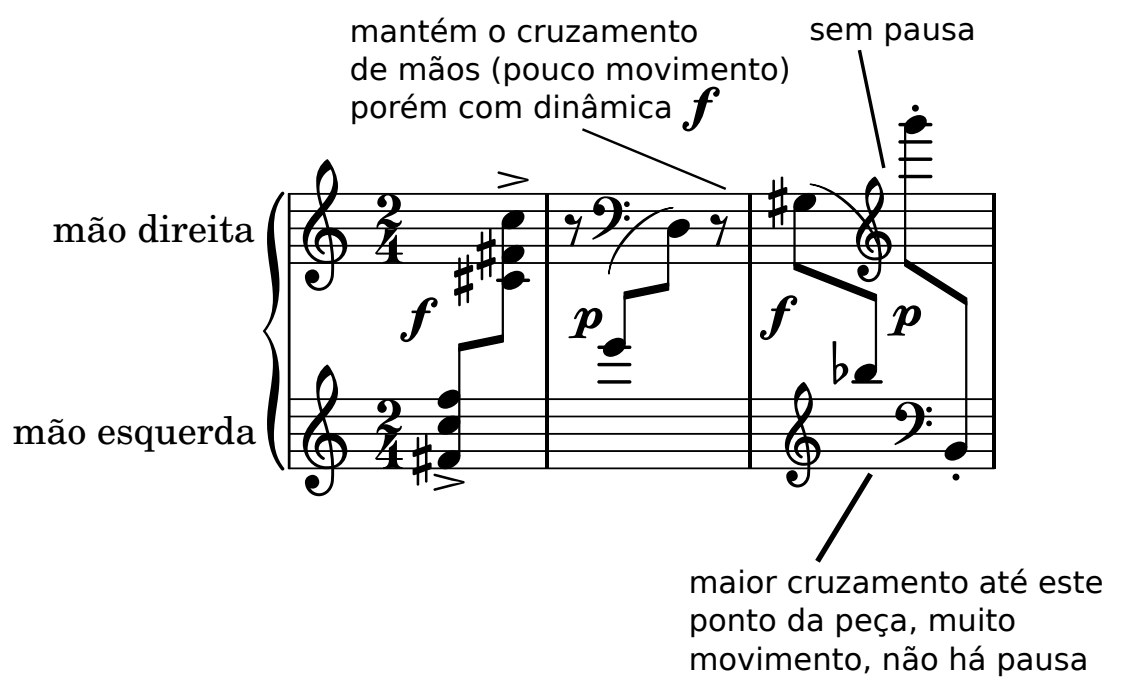

Figura 5.17: Cruzamento brusco de mãos. 


\subsection{Considerações finais}

Nesta seção correspondente à análise das Variações op.27 de Anton Webern tentamos demonstrar a importância que as noções de gesto, gesto físico e corporalidade desempenham tanto na composição quanto em uma interpretação adequada dessa obra.

Em um primeiro momento tentamos estabelecer a relação entre questões importantes relativas à corporalidade e como isso, ao nosso ver, já estava presente nas considerações iniciais sobre a construção da obra, incluindo a construção da série e de sua estrutura geral. Muito embora o foco nesta análise não tenha sido a relação entre as alturas, não nos furtamos de fazer uma minuciosa averiguação da série (vide tabela 5.2), uma vez que percebemos que a relação das alturas com os gestos físicos é indissociável. Ao nosso ver esta análise da obra de Webern — apontado como um grande estruturalista tem uma importância especial pois demonstra uma ampliação da ideia mais usual de que uma abordagem considerada estruturalista vai em sentido contrário a abordagem que nos propomos a fazer, sobre a relação da corporalidade com a estruturação de uma composição. Na análise que nos propusemos a fazer pudemos notar que o gesto físico impulsiona a maneira como a série é configurada, sendo o gesto musical não apenas uma decorrência de uma organização de notas, mas sim o oposto: o gesto influencia primeiramente a organização da série, que é difundida ao longo da música sob a influência dos gestos físicos premeditados pelo compositor. 


\section{Capítulo 6}

\section{Air de Richard Barrett}

\subsection{Introdução}

Unlesbarkeit dieser

Welt. Alles doppelt $\left.\right|^{1}$

PAUl CELAN

Neste capítulo realizaremos uma análise de uma importante obra de Richard Barrett, um influente compositor do País de Gales nascido no final da década de 1950. A obra a ser analisada, Air, foi escrita para violino e possui uma duração aproximada de seis minutos; foi dedicada à violinista Mary Oliver, no ano de 1993. Segundo o compositor (Barrett 1994), Air pode ser pensada em diferentes níveis; em um desses níveis a peça representa uma tentativa de permitir que tanto o instrumento quanto a relação do instrumento com as mãos do instrumentista determinem o material da obra, desde as alturas individuais — que são baseadas em um sistema de contração e extensão de posições da mão esquerda — à sua forma geral, onde há uma trajetória com uma tendência implícita que ascende da corda mais grave à mais aguda do instrumento. Barrett também aponta, inclusive na nota de programa da obra, que outro nível presente remete à relação das ações do arco com o processo de respiração: este processo de respiração sofre um risco crescente de colapso ao longo da obra, como veremos na análise

\footnotetext{
1"Ilegibilidade desse mundo. Tudo em dobro."
} 
a seguir. O compositor ressalta que o aspecto mais importante em seu processo criativo está justamente na ausência de distinção entre a identidade técnica e a identidade expressiva da obra.

Air, juntamente com outras duas obras para instrumentos solistas (von hinter dem Schmerz para violoncelo e knospend-gespaltener para clarineta), formam a base do último movimento, intitulado Engfürung II, por sua vez componente da obra Opening of the Mouth, composta entre 1992 e 1997. Como elaboraremos mais adiante, essas três obras são recortadas, rearranjadas e inseridas neste último movimento em uma forma mais complexa. Engfürung II possui uma duração aproximada de 30 minutos e foi escrita para uma formação atípica de dois violões (um violão clássico de dez cordas, outro com doze cordas de aço), mandolim, mandola, koto, koto baixo, flauta, viola, clarinete, contrabaixo, vibrafone e também uma gravação contendo sons manipulados de sete clarinetes baixo.

Air é uma peça importante no embasamento das nossas elucubrações acerca da corporalidade inteligente pois articula o "diálogo erótico entre corpo e intelecto" — nas palavras de Mary Oliver, citadas na nota de programa da peça ${ }^{2}-$, ampliando o instrumento para além da concepção mais usual de que o instrumento musical representa o papel de uma mera máquina de produzir notas.

\subsubsection{Breve nota biográfica}

Richard Barrett nasceu em 1959 e formou-se em genética em 1983. Desde este período é um músico muito ativo tanto na composição para grupos instrumentais e vocais, quanto na música eletrônica fixada em suporte e improvisação. Trabalhou na Universidade Middlesex de 1989 a 1992, lecionou música eletrônica no Instituto de Sonologia do Conservatório Real de Haia entre 1996 e 2001; no ano de 2009 Barrett reassumiu sua posição no Instituto. Morou em Amsterdã a partir de 1993, depois em Berlim entre 2001 e 2006, quando assumiu a cadeira de composição na Universidade Brunel

\footnotetext{
${ }^{2}$ Barrett, Richard. Air. London: United Music Publisher, 1994
} 
em Londres. Conjuntamente com Roger Redgate fundou o grupo instrumental inglês Ensemble Exposé, muito influente na produção musical do Reino Unido nas décadas de 1980 e 1990. Também atuou como codiretor desde a fundação deste grupo entre 1984, até 1993. Desenvolveu outras colaborações importantes com grupos instrumentais com o grupo de câmara belga Champ d'Action e com o grupo australiano ELISION, que realizou a primeira apresentação pública de Opening of the Mouth. Richard Barrett também é um músico ativo e reconhecido na área da improvisação. Seu duo FurT com Paul Obermeyer possui mais de 25 anos de trabalhos documentados. Barrett se apresenta regularmente com outros músicos, a exemplo da vocalista Ute Wassermann, do saxofonista Evan Parker, do violoncelista Arne Deforce e do flautista César Villavicencio, além de seu octeto $f O R C H$.

\subsection{Polifonia}

Apesar de se tratar de uma obra para violino solo — instrumento que normalmente é tratado melodicamente - Air apresenta uma situação relativamente singular: o tratamento polifônico. Se nos permitirmos adotar um conceito mais abrangente de polifonia, poderemos observar que esta peça possui características altamente polifônicas em diversos planos. Nesta análise vamos nos ater a dois deles:

- polifonia formal: o relacionamento da obra com a forma geral de Opening of the Mouth, que abarca Air;

- polifonia paramétrica e corporal: e as inter-relações das ações físicas e abstratas em jogo.

Porém antes de avançarmos nessas considerações devemos nos ater brevemente sobre o conceito aqui adotado de polifonia. Polifonia, como conceito, deve ser devidamente separada da polifonia entendida enquanto uma preocupação exclusivamente estilística, como na expressão "estilo polifônico" ou ainda "estilo polifônico da Renascença". Incluindo a noção de polifonia equivalente a uma disciplina técnica, como pretende des- 
crever inúmeros tratados de contraponto. Só depois deste tipo de separação é que podemos tornar mais abrangente o conceito de polifonia e usá-lo de modo mais produtivo em nossa análise.

Podemos descrever uma característica que pode ser atribuída à polifonia, não só enquanto estilo mas enquanto conceito, da seguinte forma: a partir da interdependência e das inter-relações de várias camadas de material musical pode-se presenciar o surgimento de um novo objeto ou evento musical genuíno, esse objeto, evento ou qualidade é o que aqui chamamos de polifonia.

Uma abordagem mais abrangente pode nos permitir obter um entendimento diferenciado de uma compreensão reducionista de polifonia que limita sua vastidão somente aos parâmetros de altura e ritmo de certos estilos musicais. Podemos aplicar a noção de polifonia para outras questões conceituais mais amplas no que se refere à composição musical, como, por exemplo, a forma e a escrita para instrumento solista.

Podemos pensar em diversas abordagens que tenham como objetivo revelar qualidades polifônicas em uma escrita para instrumento solista:

- polifonia entre elementos corporais, físicos e sonoros;

- uma polifonia de fluxos paramétricos;

- um desacoplamento dos elementos que compõem uma técnica instrumental;

- polifonia estrutural de objetos musicais, processos e técnicas mais amplos.

No seção 5.4 vimos como na obra Variações op.27 de Anton Webern há certas informações que não estão presentes na notação, mas que influenciam fortemente o resultado musical como um todo. Poderíamos ser levados a crer, neste caso também, que há uma interferência desses fluxos de informações, inclusive aqueles ligados aos movimentos corporais, à energia empregada pelo intérprete em dado momento, ou até mesmo ao aspecto visual dessas movimentações. Também já observamos como Helmut Lachenmann e outros compositores desacoplaram os elementos da técnica instrumental, 
resultando inclusive nas técnicas de notação prescritiva que tratamos e investigaremos mais adiante nesta pesquisa.

Nesta análise teremos a oportunidade de abordar dos outros tipos de fenômenos de polifonia, como a polifonia de fluxos paramétricos e o já discutido desacoplamento dos elementos da técnica instrumental.

\subsubsection{Polifonia enquanto diferenciação}

Contraponto pode ser considerado uma expressão da diferença entre dimensões na música ocidental

Adornd 3

Como aponta o compositor e musicólogo alemão Claus-Steffen Mahnkopf, a polifonia está intimamente relacionada a um sistema de diferenciações:

[...] a diferença forma uma parte inevitável de toda música; a diferença enquanto tal dá vazão à perspectiva polifônica, e é somente através da diferença - enquanto uma diferença temporalmente adjacente (na forma de simultaneidade e/ou correlação diagonal) — que a polifonia pode existir em um sentido terminológico. (Mahnkopf 2002, p.39)

Mahnkopf acredita que se faz necessário expandir a definição de polifonia para além do âmbito vertical, o que acreditamos ser de grande importância para ampliar as possibilidades de análise musical e que pode enriquecer vastamente nossa pesquisa. Para Mahnkopf o conceito de polifonia também deve incluir uma "dimensão diagonal", pois, as "relações polifônicas essenciais não são aquelas entre notas simultâneas", mas antes entre "formas", ou seja, entre "unidades rítmicas e sintáticas (figuras e gestos, por exemplo)" (p.40). Este tipo de definição de polifonia nos permitiria, por exemplo, tratar de outros componentes de um argumento musical como passíveis de agentes em um contexto polifônico. Esses componentes poderiam ser não somente alturas, mas

\footnotetext{
${ }^{3}($ Adorno 2006)
} 
também elementos ligados a outros parâmetros, aos gestos físicos e corporais, à relação entre resultado sonoro e ação física, perfazendo uma polifonia paramétrica.

Essas relações polifônicas que estamos sugerindo não emergiriam de elementos uns contra os outros de forma simples e sincrônica, mas sim "de unidades já conectadas internamente", de estratos que já possuem algum conteúdo sintático. Isso explica o uso do termo diagonal por Mahnkopf — o que nós evitaríamos, dado seu significado pouco óbvio — - o elemento polifônico não seria uma característica nem somente horizontal nem somente uma coordenação vertical, mas sim uma combinação desses dois princípios de modo a revelar uma nova qualidade antes inexistente.

Mahnkopf (2002) aponta ainda uma outra modalidade de polifonia: a polifonia formal. Ele chamou essa categoria polifônica de poliobra. Segundo ele uma poliobra corresponderia à dissociação de uma obra enquanto um todo "organicamente definido": dentro de uma obra "composta de modo orgânico" e consistente consigo mesma, podem estar localizados subcomponentes independentes, "em si mesmos obras compostas organicamente", e que fazem contribuições indispensáveis à organização do todo. Também podem ser apresentadas enquanto obras independentes. O que Mahnkopf quis aqui dizer com "organicamente"? Provavelmente ele tentou indicar obras que são autossuficientes, ou seja, que fazem sentido em si mesmas, e que possuem uma coerência estrutural próprias, são responsáveis pelas suas próprias sintaxes e poéticas. Porém, ao mesmo tempo, podem ser incorporadas em uma obra de maior fôlego, essa também autossuficiente. Porém, diferentemente dos movimentos da música tradicional, tais momentos não são necessariamente seguidos um depois do outro, mas podem ser sobrepostos e combinados de diferentes formas: simultâneas, em sequência, sincronizadas, dessincronizadas etc.

\section{Exemplos de poliobras}

Na história da música ocidental podemos encontrar diversos exemplos desse tipo de construção citado na seção 6.2.1; a seguir tentaremos dar alguns desses exemplos para melhor ilustrar como esse tipo de estratégia de construção composicional tomou forma 
no século XX.

\section{Darius Milhaud}

Um dos primeiros exemplos desse tipo de prática, com um mínimo de radicalidade nesse sentido, seriam os Quartetos de Cordas 14 e 15 de Darius Milhaud. Ambos os quartetos são obras autônomas, independentes e podem ser tocados sem a mínima menção ao outro. Porém, ao mesmo tempo, eles podem constituir um Octeto de Cordas caso sejam executados simultaneamente. Obviamente os contextos e mesmo as poéticas dessas três obras serão distintas.

\section{Luciano Berio}

Outras obras que poderiam ser classificadas como poliobras seriam, por exemplo, Chemins II, Chemins IIb, Chemins III, Chemins, IV e Chemins VI do compositor italiano Luciano Berio. A série Chemins teve início em 1964 como extensões ou versões concertantes para uma outra série de obras, essa para instrumentos solistas, as chamadas Sequenze. Sequenza VI para viola, de 1967, por exemplo, teve mais de uma recomposição, a exemplo de Chemins II, para conjunto instrumental de câmara. Assim como Chemins IV (figura 6.1) também toma como ponto de partida a Sequenze VII para oboé solo. Tanto em Chemins II (para viola e conjunto de câmara) como em Chemins IV (para oboé e onze instrumentos de cordas friccionadas) há uma evidente hierarquização do solista, e uma dependência muito forte do restante dos instrumentos em relação a esse material básico. Em nenhuma dessas duas obras, que possuem incontestável valor estético, o grupo instrumental possui uma autêntica independência, como no exemplo de Darius Milhaud.

\section{Julio Estrada}

Mais um exemplo que obrigatoriamente devemos citar trata-se de certas obras do compositor mexicano Julio Estrada, em especial seu ciclo yuunohui para instrumentos de cordas friccionadas. Nesse ciclo há quatro peças para instrumentos solistas (violino, viola, violoncelo e contrabaixo) que podem ser combinadas de diversas formas em duos, 
trios ou quarteto; como a peça para violoncelo yuunohui'yei, de 1983.

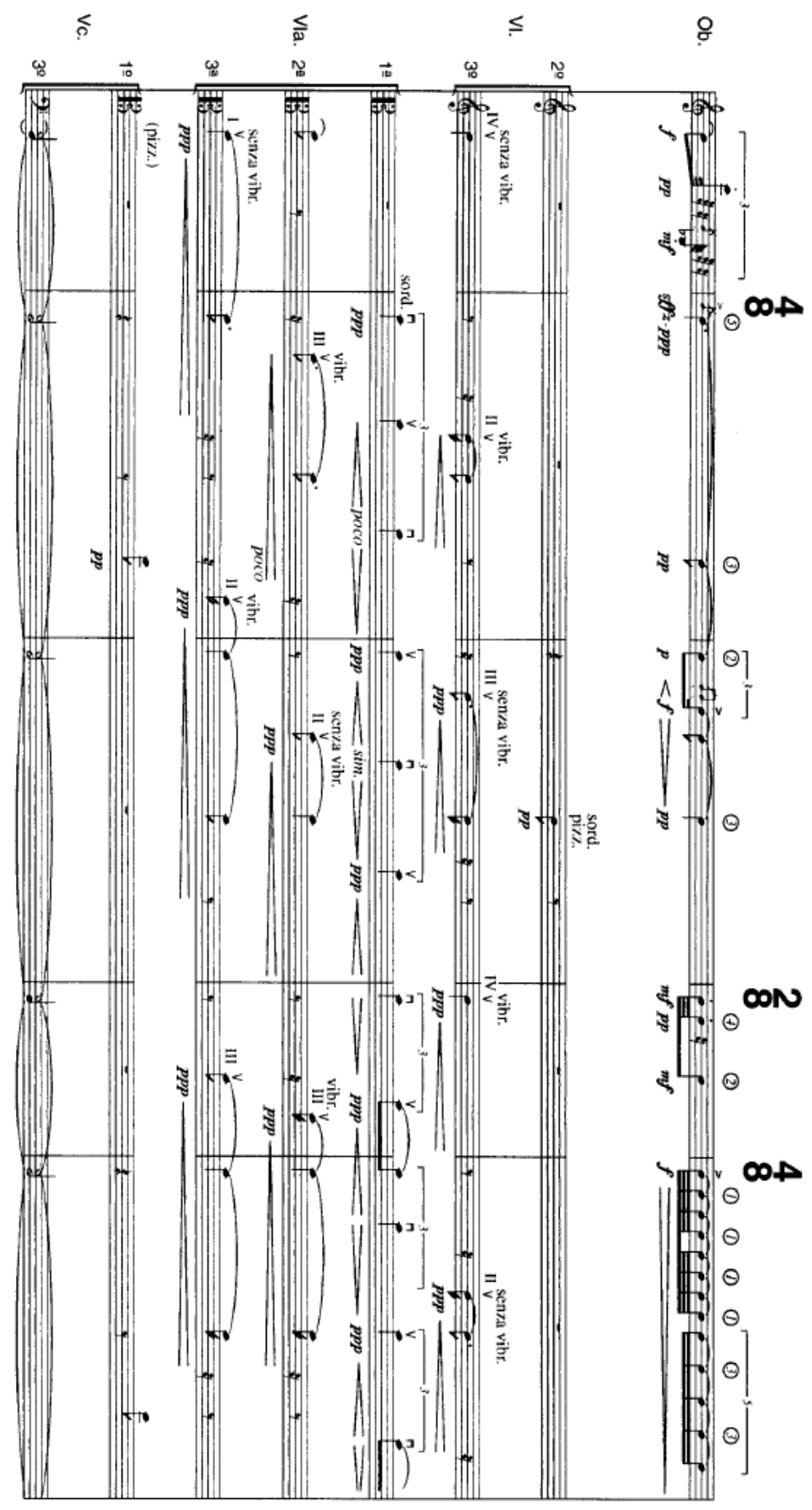

Figura 6.1: Chemins IV, baseado na Sequenze VII, para oboé e 11 cordas, de Luciano Berio.

\section{Claus-Steffen Mahnkopf}

O compositor alemão Claus-Steffen Mahnkopf, a quem nos referimos acerca de seu trabalho como teórico em vários momentos desse trabalho, talvez tenha sido um dos 
que mais radicalmente adotou a concepção de poliobra. Alguns desses trabalhos:

- Ciclo Medusa (componentes: Gorgoneion para oboé, Die Schlagen der Medusa para clarinetes, Pegasos para cravo, Stheno und Euryale para harpa. Essas obras combinadas a instrumentos adicionais formam o concerto para oboé Medusa);

- Angelus Novus (componentes: La terreur d'ange nouveau para flauta, Angela Nova para soprano e grupo instrumental, Le rêve d'ange nouveau para piano, Zweite Kammersymphonie para orquestra de câmara, La vision d'ange nouveau para violoncelo, Solitude-Sérénade para oboé piccolo e grupo instrumental);

- Ciclo Medeia (componentes: Wladmir para violino, Kammersymphonie para orquestra de câmara, Zweites Streichquartett, Meta Medeian para 30 cordas e 2 harpas);

- Hommage à Thomas Pynchon;

- Kammerzyklus (componentes: Kammerstück e Kammerminiatur para piano, Bläsertrio e Trio Basso, todos combinados em Kammerkonzert);

- Ciclo Kurtág (componentes: Kurtág-Duo para dois violões, Todesmusik I-II para metais e percussão, Hommage à Mark André para címbalo húngaro, Kurtág Cantus $I-I V$ para instrumentos de madeira solistas, todos os anteriores combinados em Hommage à György Kurtág para violão e grupo instrumental de câmara).

Como podemos perceber pelos exemplos acima, há uma grande quantidade de obras que são interconectadas de maneiras muito diversas. Notemos que não se tratam apenas de ciclos de obras, como se esperaria de um ciclo convencional. Mas tais obras, não raramente, sofrem uma realocação e interconexão mais interessante do que se esperaria de um ciclo onde as obras simplesmente são seguidas umas pelas outras.

\section{Poliobra em Richard Barrett}

Richard Barrett realizou algumas obras que poderiam ser classificadas como poliobras, a exemplo de Dark Matter, Negatives e Opening of the Mouth, além de ciclos mais 
tradicionais como After Matta e Fictions.

A obra que iremos analisar, Air para violino solo, faz parte de Opening of the Mouth, composta entre 1992 e 1997, com uma duração aproximada de noventa minutos. Mais especificamente, Air está inserida (fragmentada e rearranjada) no último movimento de Opening of the Mouth, Engfürung II, de aproximadamente trinta minutos. Opening of the Mouth foi escrita para um efetivo pouco usual composto de duas cantoras (soprano e mezzo-soprano), flauta, clarineta, percussão, mandolim/mandola, guitarra elétrica/violão de 12 cordas, violão de 10 cordas, koto/ jushichigen, violino/viola/hardingfele (instrumento similar ao violino, de origem norueguesa), violoncelo, instrumento eletrônico e música eletrônica pré-gravada. Opening of the Mouth consiste em uma série de obras que podem ser apresentadas separadamente. Porém isso não significa que quando elas sejam interpretadas sequencialmente, são na verdade fragmentadas, sobrepostas de diversas maneiras umas às outras.

O título Opening of the Mouth se refere a um ritual de cerimônia realizado no Antigo Egito durante o processo de mumificação, para restaurar o poder da fala ao morto, assim permitindo-o se proclamar diante dos juízes no mundo dos mortos. O texto inclui várias obras do poeta romeno, de língua alemã, Paul Celan; por sua vez vítima e muito ligado à catástrofe no holocausto, assim como a uma espantosa reinvenção muito pessoal da língua alemã.

As obras contidas em Opening of the Mouth podem, também, ser apresentadas separadamente:

\section{- Air (1993) para violino;}

- Charon (1994-95) para clarineta baixo;

- Inward (1994-95) para flauta contralto e percussionista, ambos amplificados;

- von hinter dem Schmerz (1992-96) para violoncelo;

- abglanzbeladen/auseinandergeschrieben (1992-96) para percussão; 
- Tenebrae para mezzo-soprano, guitarra elétrica, percussão e instrumento eletrônico;

- knospend-gespaltener (1992-93) para clarineta em dó;

- Landschaft mit Umenwesen (1996-97), música eletrônica;

- Zungenentwerzein (1996-97), música eletrônica.

Em todas essas obras (com exceção das peças eletrônicas sem performance ao vivo) a questão da fisicalidade e da corporalidade é largamente explorada. Essas peças se conjugam de diversas formas, algumas dessas possibilidades:

- instrumento solista + conjunto instrumental + segundo instrumento solista;

- instrumento solista + voz;

- instrumento solista ou duo + conjunto instrumental + voz.

Além desse aspecto sincrônico na montagens dos vários fragmentos, há também um relevante aspecto diacrônico, como, por exemplo, algumas sobreposições entre finais de seções e início de outras, o que também ocorre em Negatives. O movimento final, denominado Engfürung II, apresenta um tratamento mais radical no que se refere à estrutura formal, interconectando três peças para instrumentos solistas Air, von hinter dem Schmerz e knospend-gespaltener e Tenebrae, de forma altamente fragmentada. A esses instrumentos são adicionados, ao longo de trinta minutos, dois violões (violão clássico de dez cordas e violão com cordas de aço de doze cordas), mandolim, mandola, koto, jushichigen (koto baixo), flauta, viola, clarineta contrabaixo, vibrafone e música eletrônica. Na tabela 6.1 está o esquema geral das entradas na montagem realizada tendo por base as obras anteriormente citadas. 


\begin{tabular}{|c|c|}
\hline $3^{\prime} 00^{\prime \prime}$ & Tenebrae \\
\hline $244^{\prime}$ & knospend-gespaltener + triângulo do grupo Tenebrae \\
\hline $30^{\prime \prime}$ & Tenebrae + jushichigen do grupo Engführung \\
\hline $48 "$ & knospend-gespaltener + guitarra elétrica \\
\hline $21 "$ & Tenebrae + jushichigen + violão de 10 cordas \\
\hline $14 "$ & von hinter dem Schmerz + piccolo \\
\hline $25 "$ & knospend-gespaltener + violão 10 cordas \\
\hline $43 "$ & Tenebrae + sampler \\
\hline $51 "$ & knospend-gespaltener + percussão \\
\hline $14 "$ & von hinter dem Schmerz + piccolo \\
\hline 1'34" & knospend-gespaltener + percussão \\
\hline $14 "$ & Tenebrae + sampler + bamdolin \\
\hline $11 "$ & Air + mezzo-soprano \\
\hline $13^{\prime \prime}$ & knospend-gespaltener \\
\hline $15 "$ & Air + mezzo-soprano \\
\hline $14 "$ & von hinter dem Schmerz + piccolo \\
\hline $22 "$ & Air + mezzo-soprano \\
\hline $27 "$ & knospend-gespaltener + mezzo-soprano \\
\hline $64 "$ & Tenebrae + violão 10 cordas \\
\hline $14 "$ & knospend-gespaltener + mezzo-soprano \\
\hline $14 "$ & von hinter dem Schmerz + piccolo \\
\hline $10 "$ & Tenebrae \\
\hline $31^{\prime \prime}$ & Air \\
\hline $18 "$ & knospend-gespaltener \\
\hline $32 "$ & Air \\
\hline 1'20" & knospend-gespaltener \\
\hline $14 "$ & von hinter dem Schmerz \\
\hline $28 "$ & knospend-gespaltener \\
\hline $72 "$ & Air \\
\hline $25 "$ & knospend-gespaltener \\
\hline 1'52" & Air \\
\hline $20 "$ & vozes \\
\hline 1'10" & von hinter dem Schmerz \\
\hline 4'55" & Tempo $=57+$ vozes \\
\hline 1'30" & grupo Engfürung \\
\hline $5^{\prime}$ & von hinter dem Schmerz + vibrafone + clarineta contrabaixo \\
\hline 1'40" & vozes + percussão + clarineta contrabaixo \\
\hline
\end{tabular}

Tabela 6.1: Estrutura geral de Engfürung II, último movimento de Opening of the Mouth. Note a crescente duração das seções referentes à obra Air. 


\subsubsection{Semantificação da Técnica Instrumental}

\section{Polifonia para instrumento solista}

Voltando à outra categoria de polifonia, também inspirada nos textos de Mahnkopf, gostaríamos de retomar a questão da polifonia paramétrica, por vezes envolvendo componentes físicos, corporais. A maior parte desses exemplos pode ser encontrada em algumas obras do repertório contemporâneo. Aaron Cassidy (Cassidy 2002) fala deste tipo de polifonia (polifonia paramétrica) quando menciona que algumas das mais fascinantes pesquisas na "música polifônica complexa estão sendo realizada com experimentos focados em polifonia em apenas um instrumento". Mais adiante ele afirma que essa questão tem tomado muitas formas, a exemplo das polifonias paramétricas de Brian Ferneyhough, como nas "estratificações de timbre e de performance" em Unity Capsule, nos solos escritos em várias pautas como em Mnemosyne ou certos trechos de Kurze Schatten II. Já outros compositores, como Helmut Lachenmann ou Klaus K. Hübler desenvolveram um tipo de escrita onde componentes da técnica instrumental, antes indistinguíveis e indiferenciáveis, são desacoplados e diferenciados, fazendo surgir um novo tipo de qualidade polifônica.

\section{Polifonia paramétrica e gestual}

Como ilustração de polifonia gestual gostaríamos de mencionar o exemplo da obra Metallic Dust para clarone solo, do compositor estadunidense Aaron Cassidy. É interessante que se note como o resultado sonoro é uma mediação entre duas sugestões bem definidas de gestos bastante diferenciados: um gesto contínuo, e uma outra camada com uma alternância rápida de gestos; endossado pela indicação na partitura "strangely sinuous; smooth, set against more aggressive mouth layer' ${ }^{2}$ (figura 6.2. Observem na figura que há duas partes distintas, a pauta superior corresponde às ações da boca e sistema respiratório do instrumentista; já a parte inferior, às mãos. Os padrões gestuais de cada uma dessas camadas operam de modo "totalmente independente e não-linear",

\footnotetext{
4"Estranhamente sinuoso, liso; contaposto à camada mais agressiva da boca"
} 
segundo o autor (Cassidy 2002, p.158). O resultado dos gestos físicos atribuídos para a boca e para as mãos, durante toda a duração da obra, são muito claramente diferenciados tanto sonora quanto visualmente. Assim como no já mencionado trecho da partitura (figura 6.2), a camada correspondente às mãos do clarinetista mostra que elas realizam um gesto relativamente suave e fluido, simultaneamente na outra camada há uma pequena sequência de gestos, de natureza completamente diversa, mais agressivos, assertivos e energéticos, que incorporam, ao contrário da outra camada mais uniforme e simples, uma quantidade relativamente grande de técnicas instrumentais em um período curto de tempo combinando ações:

- da parte frontal da boca, língua contra os dentes com diferentes articulações e durações;

- da parte posterior da boca, as acciaccature de ataques guturais, que desestabilizam a coluna de ar e a embocadura;

- e finalmente as oscilações de respiração e diafragma, as pulsações smorzato.

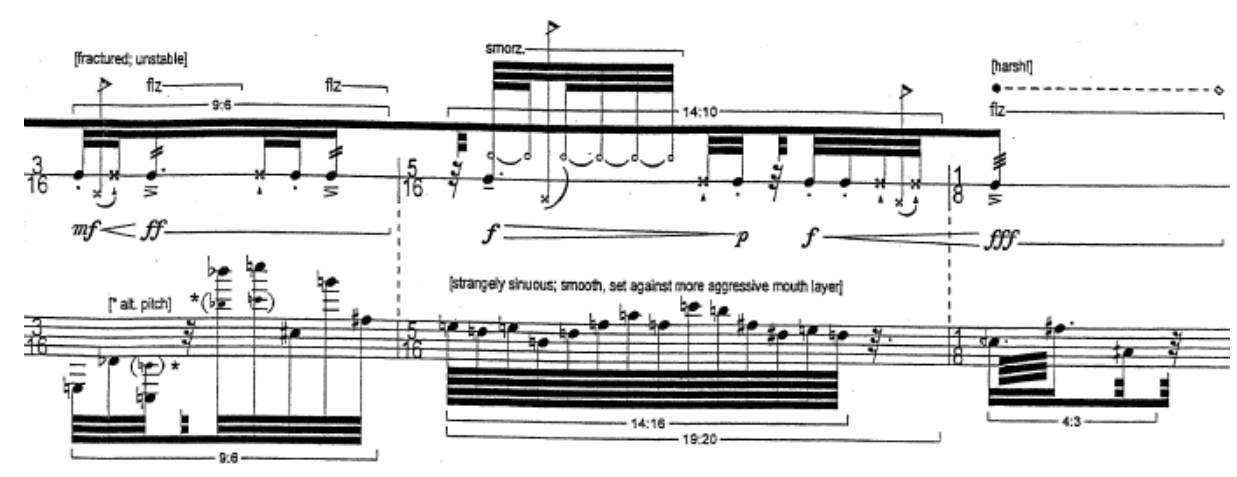

Figura 6.2: Trecho de metallic dust para clarineta baixo solo de Aaron Cassidy.

Pode-se rebater que tal abordagem da escrita e da técnica instrumental não constitui um exemplo genuíno de polifonia, uma vez que o resultado sonoro, apesar de ser fruto de uma interação complexa entre gestos diferenciados, se revela na verdade na forma de um novo e único gesto, ou uma única camada. Acreditamos que tal interpretação 
seja fruto da já mencionada concepção de polifonia enquanto estilo musical. Devemos perceber que, inegavelmente, cada uma dessas camadas contribui de modo essencial para a formação de um sentido no gesto musical, e que cada uma delas pode ser perfeitamente percebida enquanto entidade individual.

\subsection{Forma}

\subsubsection{Inserção de Air em Opening of the Mouth}

Os padrões utilizados para a fragmentação das seções das três peças solistas (knospendgespaltener, von hinter dem Schmerz e Air) que servem de base para a composição do último movimento de Opening of the Mouth, Engfürung II, podem revelar propriedades interessantes sobre a principal peça em questão, Air. Como podemos observar nas tabelas 6.1 e 6.2 knospend-gespaltener para clarineta é a primeira dessas peças a ser inserida. Tal peça é dividida em treze partes com um padrão de duração mais variado que as outras duas peças: $24,48,25,51,94,13,27,14,18,80,53,28$ e 25 segundos. No caso da peça para violoncelo solo von hinter dem Schmerz há um padrão de uma outra natureza, observamos sete seções com durações de catorze segundos, seguidas de duas longas seções de seis e cinco minutos, aproximadamente. E finalmente Air, que possui um padrão onde as durações ficam cada vez maiores: 11, 15, 22, 31, 32, 55, 72 segundos e 1 minuto e 52 segundos, como indica a tabela 6.2 . 


\begin{tabular}{|c|c|c|c|}
\hline entrada & knospend-gespaltener & von hinter dem Schmerz & Air \\
\hline \hline 1 & $24^{\prime \prime}$ & $14^{\prime \prime}$ & $11^{\prime \prime}$ \\
\hline 2 & $48^{\prime \prime}$ & $14^{\prime \prime}$ & $15^{\prime \prime}$ \\
\hline 3 & $25^{\prime \prime}$ & $14^{\prime \prime}$ & $15^{\prime \prime}$ \\
\hline 4 & $51^{\prime \prime}$ & $14^{\prime \prime}$ & $22^{\prime \prime}$ \\
\hline 5 & $94^{\prime \prime}$ & $14^{\prime \prime}$ & $31^{\prime \prime}$ \\
\hline 6 & $13^{\prime \prime}$ & $14^{\prime \prime}$ & $32^{\prime \prime}$ \\
\hline 7 & $27^{\prime \prime}$ & $14^{\prime \prime}$ & $55^{\prime \prime}$ \\
\hline 8 & $14^{\prime \prime}$ & $6^{\prime} 05^{\prime \prime}$ & $1^{\prime} 52^{\prime \prime}$ \\
\hline 9 & $18^{\prime \prime}$ & 5 & \\
\hline 10 & $80^{\prime \prime}$ & & \\
\hline 11 & $53^{\prime \prime}$ & & \\
\hline 12 & $28^{\prime \prime}$ & & \\
\hline 13 & $25^{\prime \prime}$ & & \\
\hline
\end{tabular}

Tabela 6.2: Durações de seções nas peças solistas

\subsubsection{Modelo Formal da Respiração}

A tabela 6.2 revela que há uma clara intenção do compositor ao organizar as proporções entre as seções das peças e como elas são incorporadas pelo último movimento de Opening of the Mouth. Há três padrões bem delimitados, no caso de Air as durações das seções são cada vez maiores. O compositor aponta, na nota de programa $5^{5}$ da obra, que o processo de respiração representa um modelo para a construção da obra, tanto ao nível das frases e articulações, quanto em seu formato em um plano de maior fôlego. Tanto a ação do arco quanto a forma geral da peça são ligados ao processo de respiração. Se observarmos a figura 6.3 notaremos que, de fato, há um claro processo de perda de energia, não somente as seções ficam cada vez mais lentas, como também a densidade e a energia dos materiais vão diminuindo gradualmente durante a obra, como se estivesse em andamento um processo de crescente escassez de ar.

Essa perda de energia pode ser relacionada a um lento processo de uma "respiração em crescente [...] ameaça de colapso" (Barrett 1994) $)^{6}$, Tal processo é extremamente ligado às ações do arco, aos tamanhos das frases e à densidade acústica dos objetos

\footnotetext{
5 (Barrett 1994)Também disponível em http://www.ump.co.uk/Barrett/rb-Air.htm.
}

${ }^{6}$ Barrett, Richard, Air. London: United Music Publisher Ltd., 1994 
sonoros.

Observando com atenção a figura 6.3 podemos perceber algumas demarcações bem claras entre seções. Pode-se perceber também que as durações dessas seções ficam cada vez maiores e menos densas. 


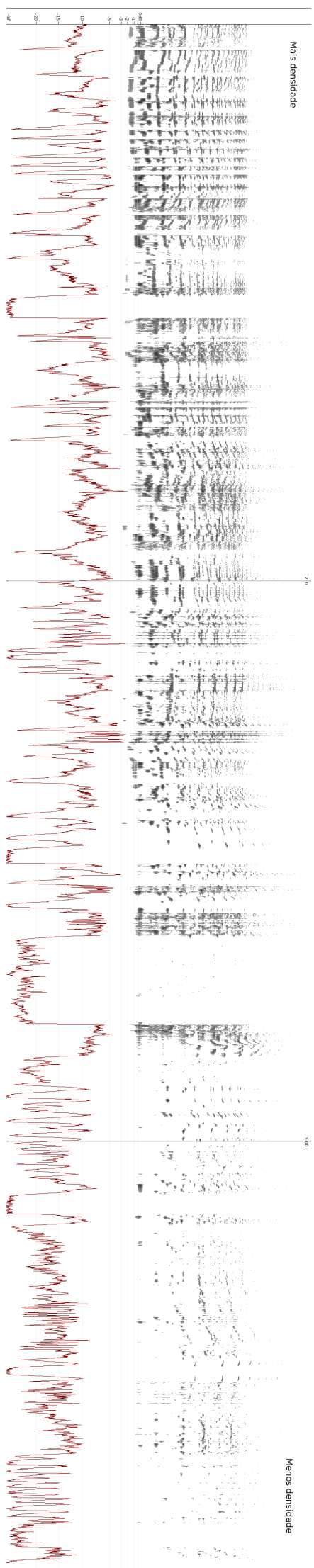

Figura 6.3: Representação do espectrograma (preto) e da amplitude de Air (vermelho), duração total da peça. 
Há um outro gesto de grandes proporções que toma forma durante a obra; não só a peça perde energia como também os materiais se iniciam no grave, com uma tendência a serem rugosos (cordas $I V$ e III, muita pressão, dinâmicas fortes) e aos poucos o compositor vai passando a utilizar cada vez mais as cordas agudas, como podemos observar nas figuras 6.4, 6.5, 6.7, 6.8, 6.9 e 6.10. Nessa série de figuras as cordas estão indicadas através de cores para uma melhor visualização do processo em questão (corda $I V$ : azul; corda $I I I$ : amarelo, corda $I I$ : vermelho e corda $I$ : verde).

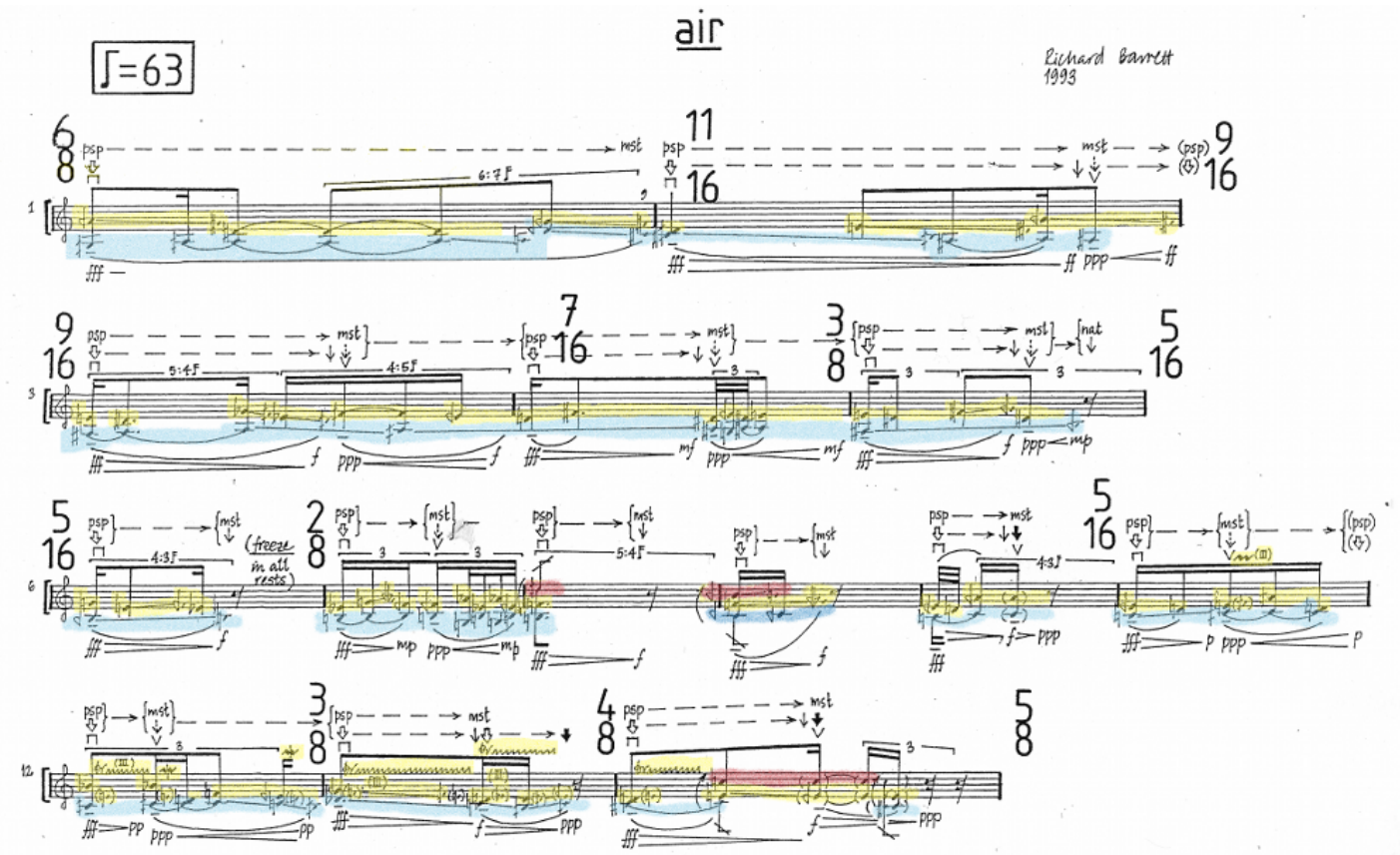

Figura 6.4: Compassos 1 a 14 - com marcações para as cordas IV (azul), III (amarelo), II (vermelho) e I (verde). 


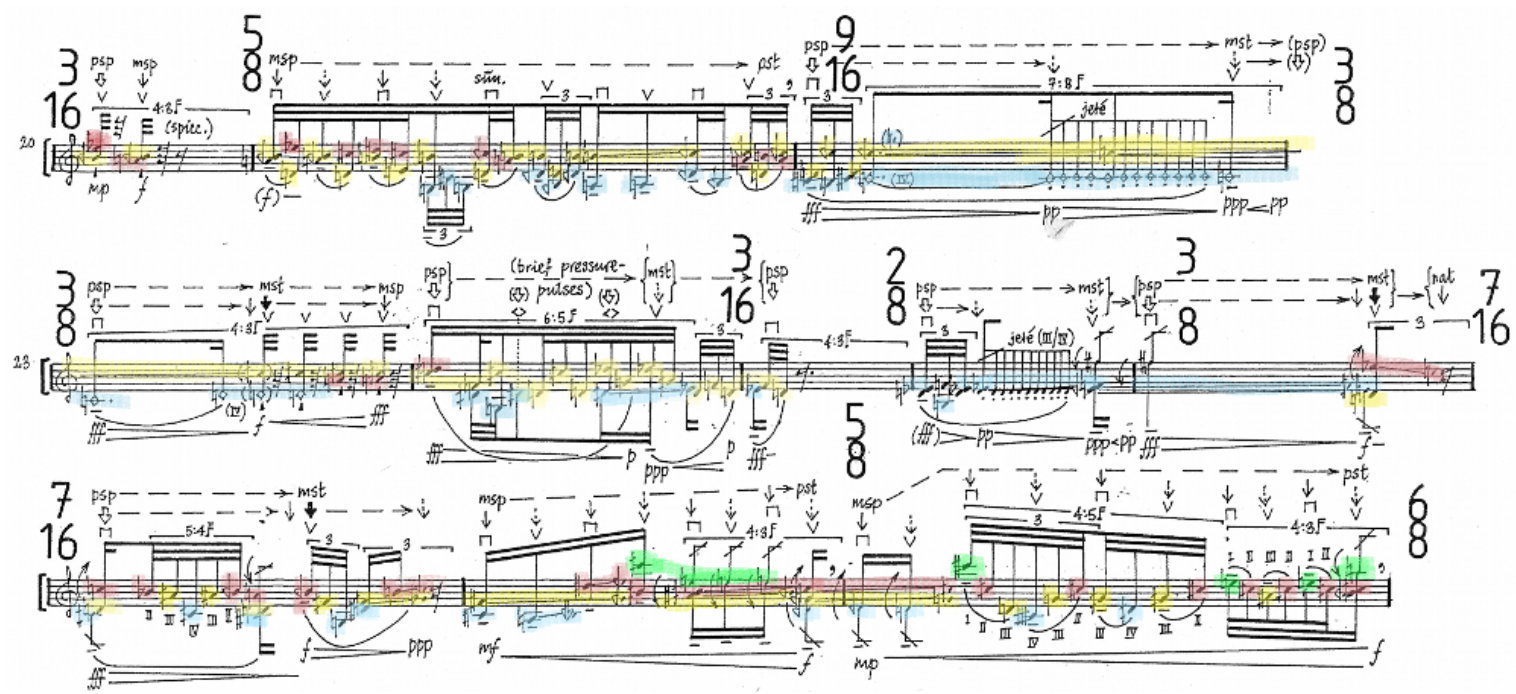

Figura 6.5: Compassos 20 a 30.

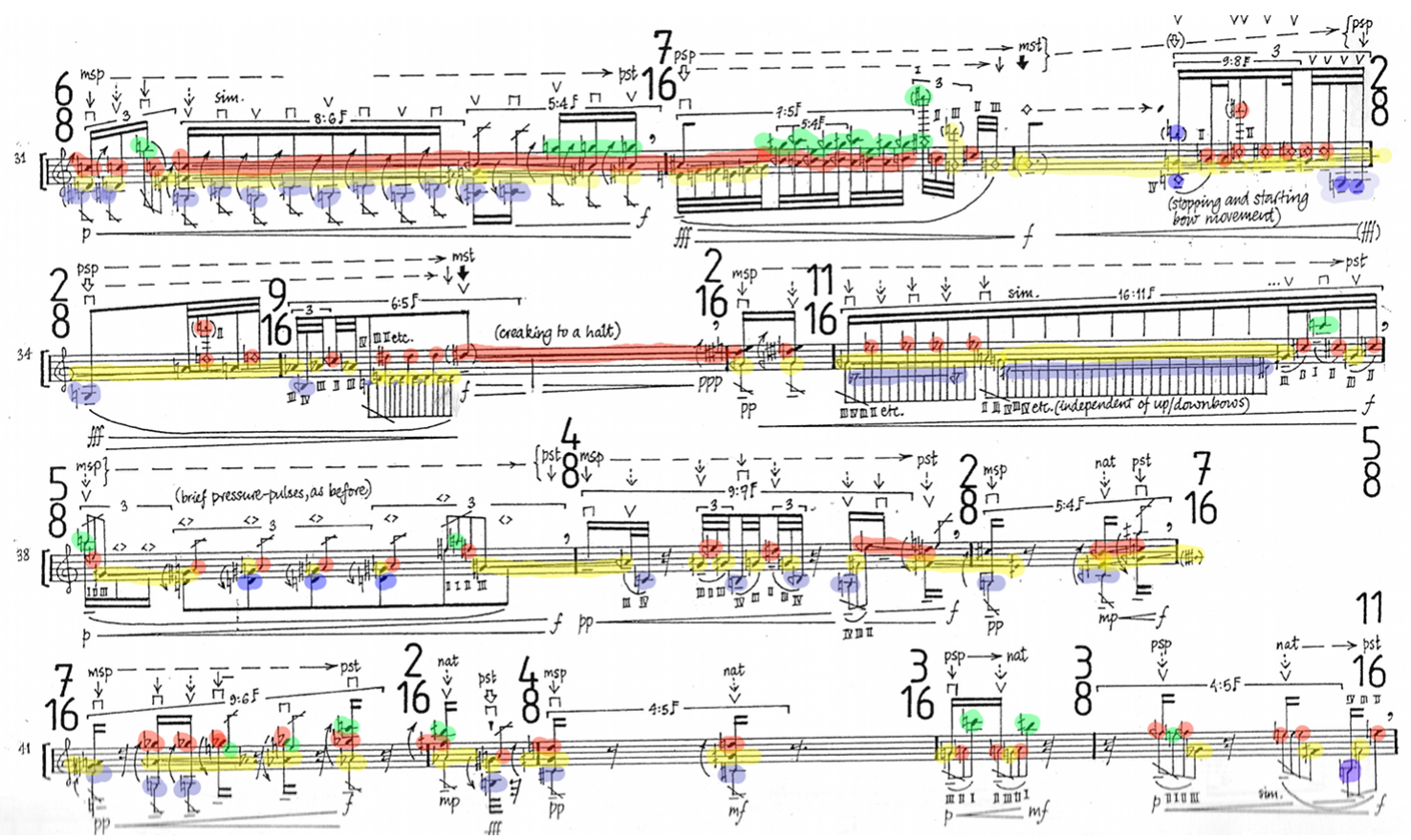

Figura 6.6: Compassos 31 a 44. 

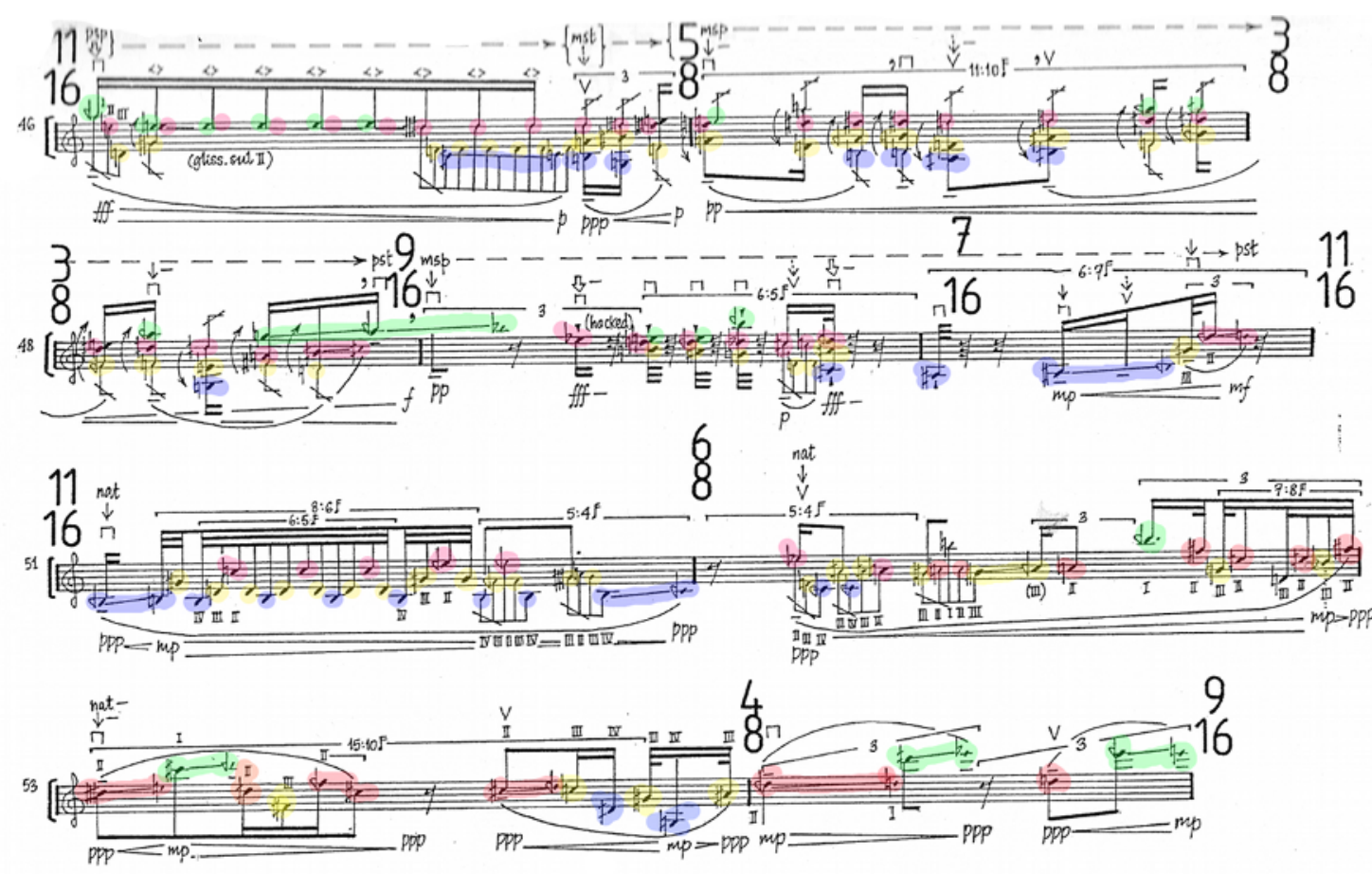

Figura 6.7: Compassos 46 a 54 .

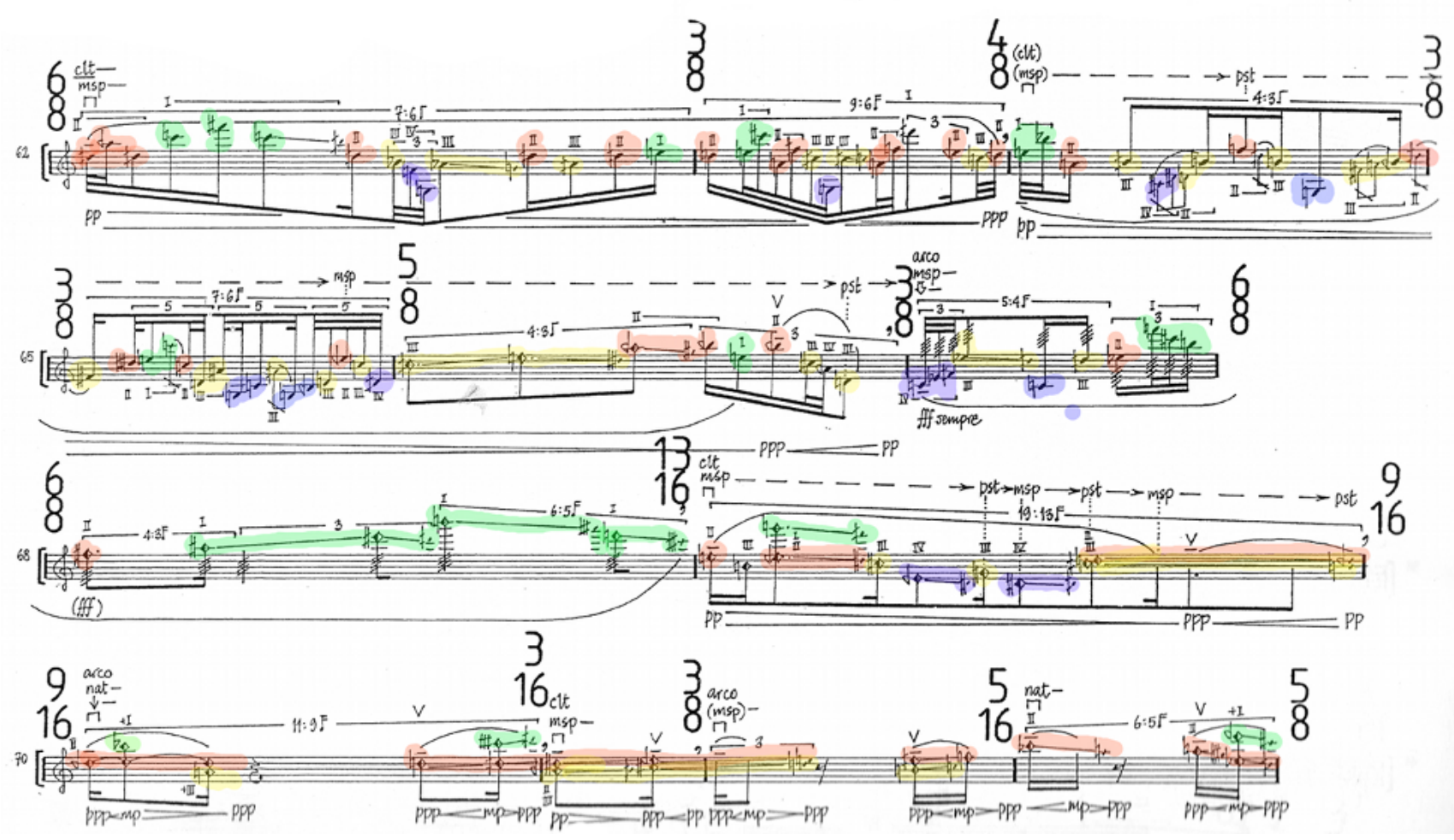

Figura 6.8: Compassos 59-73. 


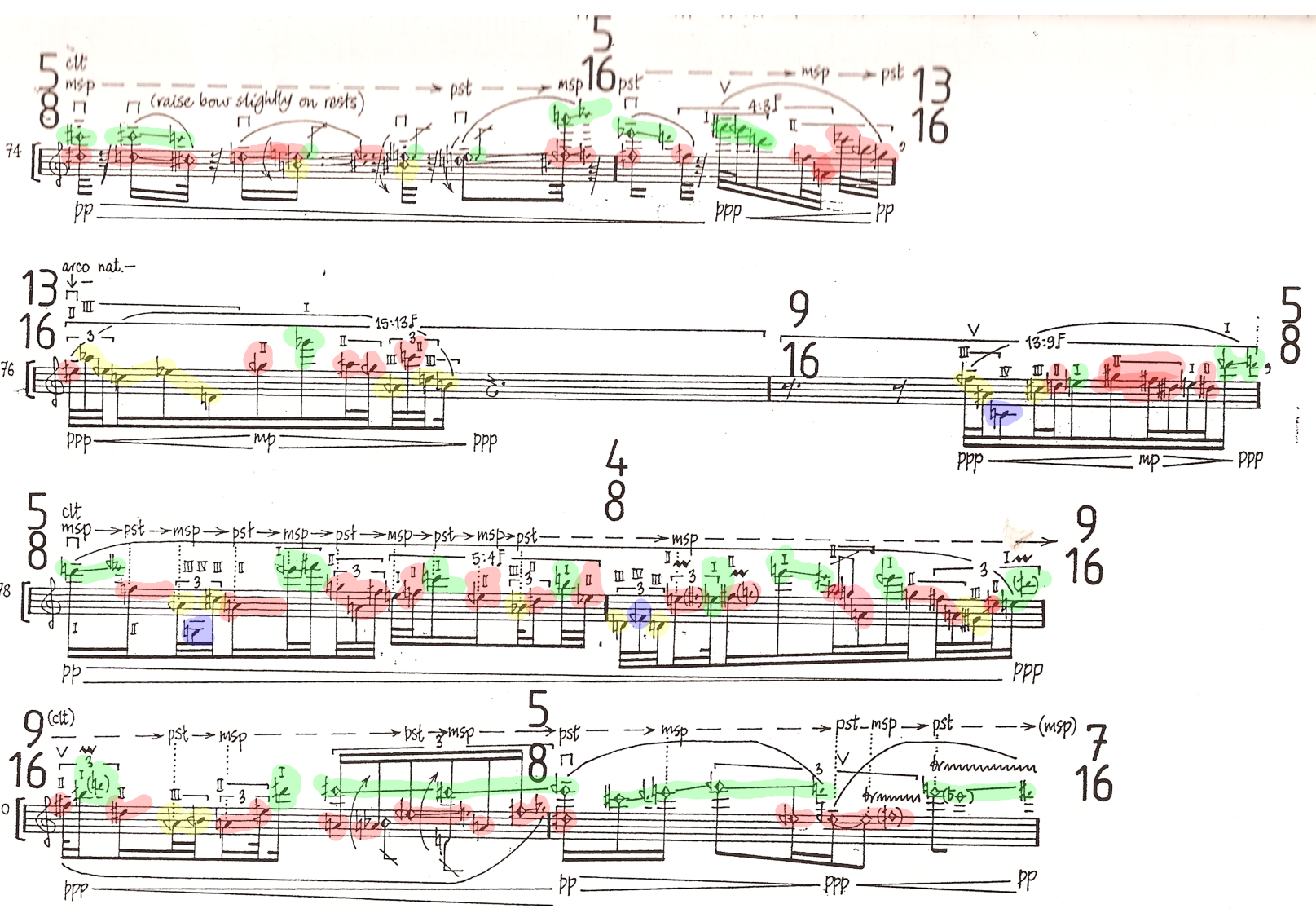

Figura 6.9: Compassos 74 a 81 .
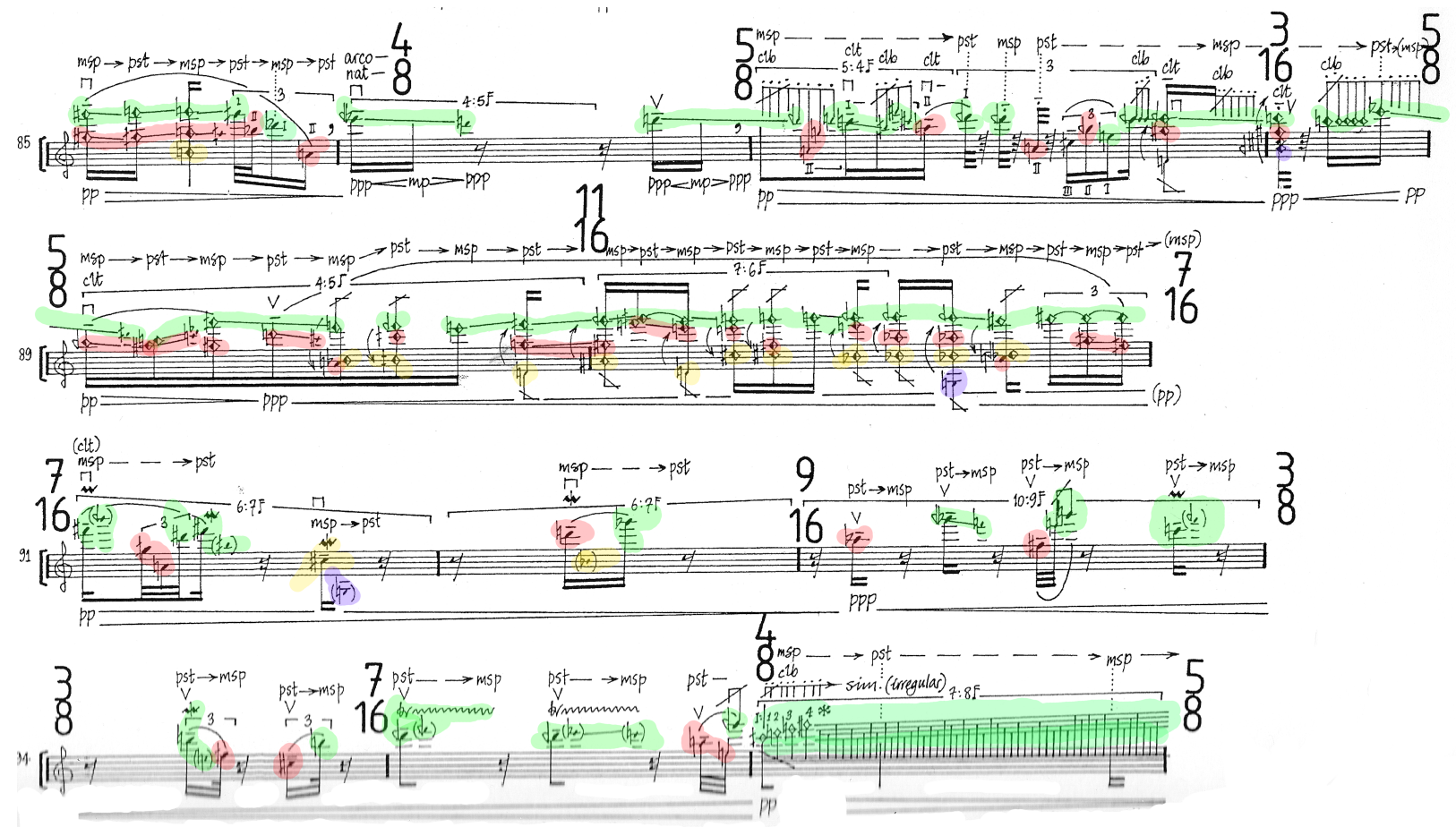

Figura 6.10: Compassos 85 a 96 . 


\section{Ações da mão direita e esquerda}

Especificações que concernem à notação prescritiva para a mão esquerda não são incomuns no repertório para violino no século XX. Um exemplo notório é do compositor italiano Luciano Berio em sua Sequenza VIII. Em uma das partes centrais da peça o compositor deixa de especificar as alturas individualmente, em vez disso ele prefere determinar a posição, a corda e o dedilhado a ser repetido muitas vezes, como na sequência $[1,4,2,3,2,1,3,4,0,1,3,2,1,2,4,2]$. O motivo que levou o compositor a utilizar tal estratégia reside no fato de que se quis enfatizar o dedilhado como um elemento composicional. A mesma passagem poderia ter sido escrita inteiramente com alturas, porém certa ideologia composicional teria impregnado com menos ênfase a notação musical. Esse último motivo pode se aplicar a muitos casos de notação prescritiva.

Mieko Kanno assim se refere à decisão composicional de Berio a respeito desse aspecto prescritivo da notação de Sequenza VIII:

A única diferença é o grau de sensibilização que o intérprete tem da figuração com a qual a passagem é composta.[...] Entretanto pode-se atribuir o caráter particular da maneira que a notação prescritiva de Berio dramatiza a articulação da música. [...] A questão se a notação prescritiva serve melhor a peça ou não é então respondida pela forte correspondência - e integridade estética - que existe entre as formas visuais e sonoras da peça (Kanno 2007, p.240-1).7

\footnotetext{
7'The only difference is the degree of awareness the performer has of the figuration with which the passage is composed. But even this procedural difference may become 'obsolete', for example when the performer memories the passage, since memorization of a passage of this complexity and speed largely depends on habitual motor-movement memory rather than on intellectual thought processes which occur during performance. Nevertheless, one can attribute the particular character of Berio's prescriptive notation to the way dramatizes the articulation of the music. The passage continues in its arabesque style for a while and the duration of the whole passage allows the schematic pattern to come to the fore of the listener's perception. Here bowing articulation comes to play a decisive role. The bowing pattern remains the same for a large part of the passage and each four-quaver unit also completes a down-up circulation of the bowing movement. In the first unit in the above example, the performer can emphasize the repetition of the four-quaver pattern by phrasing each pattern in a uniform way, such as adding a slight accent at the beginning of each down-bow (note G). Such articulation needs to be discreet if we want to avoid any mannerism: the following line in the score (starting with the note A) should be played with a seamless bow delivery - doing so will bring out the non-repetitive melodic sequence that is new in this line in contrast to the beginning of the passage in the preceding line. Such an interpretation is indeed justifies by the notation. In fact, if the notation has any value to the performer beyond communicating the sonic information,
} 
Outros compositores utilizaram a notação prescritiva não somente para as ações da mão esquerda, mas também para as ações relativas ao arco. Há uma enorme gama de possibilidades quando se explora a interação entre o arco e a corda em vibração.

As ações da mão direita têm muito mais significância do que aquelas da mão esquerda para se atingir uma certa gama e qualidade de expressão em instrumentos de cordas friccionadas (Kanno 2007, p.243).

Um dos motivos para essa maior gama de possibilidades expressivas reside no fato que o violino pode dinamicamente modificar os parâmetros de produção sonora relativos à mão direita durante a execução de um número arbitrário de dedilhados na mão esquerda, podendo modificar tais parâmetros em velocidades e métricas independentes entre si como também independentes em relação à outra mão.

As ações correspondentes ao arco do violino possuem três dimensões principais:

- velocidade;

- pressão;

- ponto de contato.

Combinações dessas variáveis são capazes de criar uma gama muito grande de possibilidades. Além é claro, de outros gêneros de ações, como os tipos de arcada, ou ações e articulações como spiccato, martelé, jeté, staccato, ricochet etc.

Na obra Air a partitura é apresentada em cinco camadas de material, geralmente nessa ordem (ver figura 6.11):

1. pontos de contato do arco;

2. pressão do arco;

it is this power of supplementing musical articulation by the graphic form of expression. But the subtlest of all features of this passage is the sense of automation it creates in the music. The piece as a whole is predominantly lyrical, and there are two 'scherzi' (including this passage) which act as a contrast to the rest of the piece. The feeling of an unstoppable cascade of fast notes, of getting out of control and being driven by its won momentum, is best represented by Berio's notation. The question as to whether or not the piece is best served by prescriptive notation is thus answered by the strong correspondence - and hence aesthetic integrity - existing between the visual and sonic forms of the piece" 
3. arcadas (para cima ou para baixo);

4. alturas, ritmos e ações da mão esquerda;

5. envelopes dinâmicos.

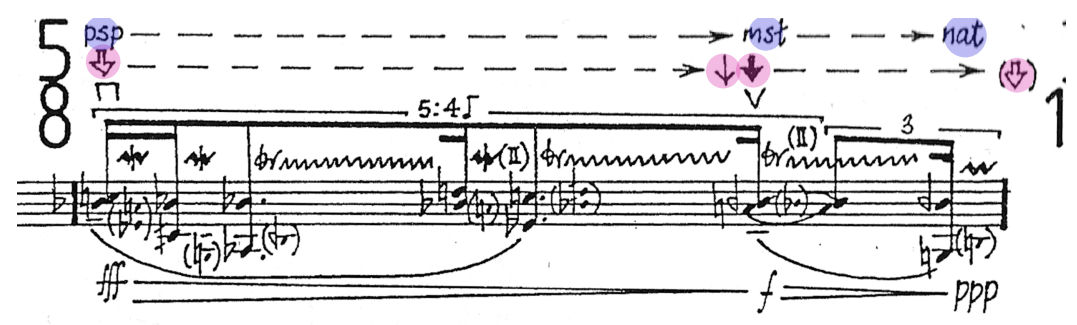

Figura 6.11: Compasso 19 de Air

Há uma clara diferença entre as camadas que utilizam um método descritivo ou prescritivo de notação musical. Podemos observar uma predominância visual dos elementos relativos às alturas e ritmos, talvez herdada pela própria tradição da notação musical. Esses elementos prescritivos (ponto de contato do arco, pressão do arco e envelopes dinâmicos) são aplicados às outras camadas que se utilizam de notação descritiva.

\section{Importância das camadas}

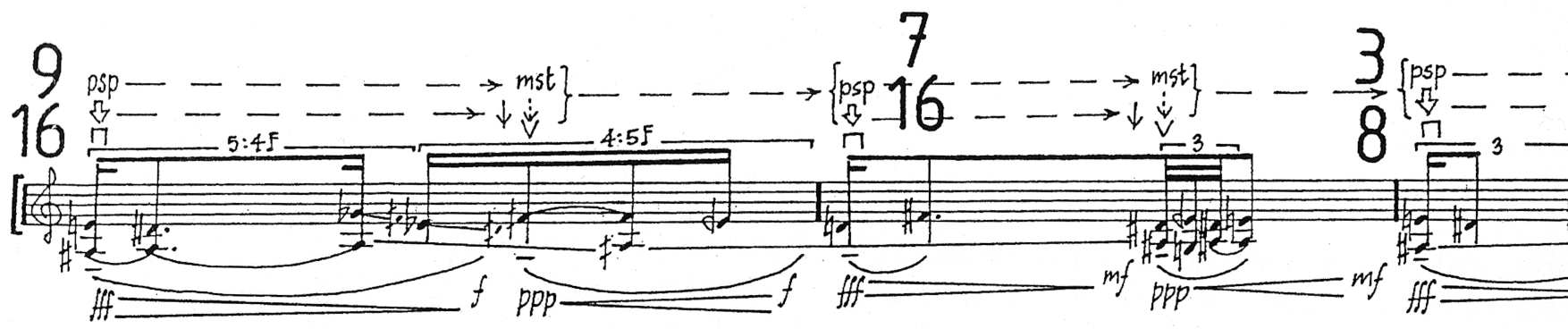

Figura 6.12: Compassos 3 e 4 de Air

Há uma divergência sobre esse aspecto nos métodos de notação utilizados por certos compositores contemporâneos. Em uma obra como o Terceiro Quarteto de Cordas de Klaus K. Hübler, utiliza-se um outro método de notação em que cada uma dessas camadas possui o mesmo nível de importância visual na partitura (Hübler 1985). 
A abordagem que o compositor Richard Barrett adota tende a ser mais clara para o intérprete, pois se conforma mais à tradição da notação, reservando às alturas e aos ritmos uma representação privilegiada, deixando os outros componentes musicais sempre em relação a essa referência principal (vide por exemplo a figura 6.12). Kanno aponta que tal abordagem, do ponto de vista do intérprete, é mais conveniente para o aprendizado da peça (Kanno 2007, p.244). Porém tal decisão pode ser enganadora em uma primeira observação, pois somos levados a crer que a informação mais importante estará justamente na camada correspondente às alturas e ritmos, e que as demais camadas de informação serão apenas qualidades adicionais dadas a uma ideia já clara nas alturas. O que observamos, contudo, é justamente o contrário. As camadas que poderiam ser entendidas como um suplemento para as camadas referente às alturas e durações, na verdade retem grande parte da informação musical relevante para a interpretação da peça.

Nos exemplo referentes às figuras 6.11 e 6.12 podemos observar tal aspecto da escolha da representação na notação, caso ignorássemos as indicações da mão direita, que possuem um área consideravelmente menor na notação musical, não seria possível perceber de fato os gestos que essa notação tenta comunicar.

\section{Notação das camadas}

A primeira camada se refere à posição do arco na corda, onde é utilizada uma forma abreviada das indicações tradicionais, como indicado na tabela 6.3 .

\begin{tabular}{|c|c|}
\hline mst & molto sul tasto \\
\hline pst & poco sul tasto \\
\hline nat & posição normal \\
\hline psp & poco sul ponticello \\
\hline msp & molto sul ponticello \\
\hline
\end{tabular}

Tabela 6.3: Posição do arco na corda 
As dinâmicas, por exemplo, são também muito importantes. No caso dessa partitura elas também ocupam um lugar de destaque, logo após os parâmetros mais tradicionais da altura e do ritmo. Nos dois exemplos que mencionamos anteriormente (figura 6.12 e 6.11 já podemos notar que há uma relação muito forte entre as dinâmicas e os outros dois parâmetros (da posição do arco e da pressão do arco).

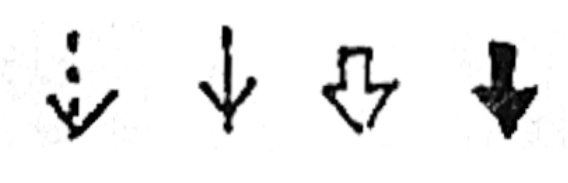

Figura 6.13: Símbolos referentes à pressão do arco

Interdependência da ação entre as camadas Há uma ligação muito forte no próprio processo de produção sonora em instrumentos de cordas friccionadas entre a dinâmica, a pressão do arco e a velocidade. Não se pode determinar independentemente esses três parâmetros, pois eles são altamente conectados do ponto de vista da própria ação. Por exemplo, para uma dada dinâmica e uma dada pressão do arco, somente uma gama muito restrita de velocidades estarão disponíveis. Assim como para uma certa velocidade e uma certa pressão, somente uma gama dinâmica limitada poderá ser utilizada pelo compositor. Na partitura de Air, apesar da velocidade do arco não estar escrita, ela representa também uma camada oculta, que não necessita de uma representação prescritiva, já que ela pode ser determinada pelas demais instruções referentes às camadas restantes. O som resultante pode variar muito em seu timbre, e aí está a importância fundamental desse tipo de abordagem. Um som com uma certa dinâmica, digamos forte, e uma pressão muito baixa, terá uma grande velocidade para tentar compensar a contradição entre os outros dois parâmetros, resultando em um som entre aerado e flautado, e que talvez, apesar da intenção do intérprete e possivelmente já previsto pelo compositor, fracasse em obter a dinâmica indicada, mas tal método descreveu com clareza o objeto sonoro pretendido. Para qualquer indicação em que a dinâmica e a pressão correspondam entre si, e a velocidade do arco seja muito elevada, 
um som "aerado" será obtido. Na hipótese contrária, se a velocidade do arco fosse menor do que a esperada para uma dada dinâmica e uma dada pressão, um som com um timbre mais ruidoso ocorreria. Se apenas variarmos a velocidade do arco, poderemos obter desde um timbre sem fundamental, somente com harmônicos ( "flautando"), até um timbre totalmente ruidoso, sem nenhum tipo de altura definida.

A camada referente às dinâmicas possui uma grande importância e está muito ligada à pressão do arco e ao ponto de contato do arco. Observemos como essa conexão ocorre na primeira seção da obra.

\subsubsection{Seções}

\section{Primeira seção (compassos 1 a 19)}

Como mencionamos no início deste capítulo, Air é baseada no processo de respiração. Esse processo pode ser percebido muito claramente não somente na primeira seção, mas também na trajetória de toda a peça. Há mesmo um componente metafórico em como as arcadas, a pressão do arco e o ponto de contato do arco funcionam, como é colocado pelo próprio compositor na nota de programa:

[...] há uma relação de analogia entre os movimentos do arco e o processo de respiração, que deve ser enfatizado na performance: arcadas para baixo como expiração, e arcadas para cima como inspiração... quaisquer distorções resultantes ou descontroles no som devem ser tidos como estágios no processo de composição, envolvendo um colapso gradual ou 'expiração' do modelo inicial. (Barrett 1994)

\footnotetext{
8"At one level, it represents an attempt to allow the instrument - and its relationship to the hands of the player - to determine the material of the work (a feature common to all of my growing body of solo works since about 1986, but taken to further extremes here), from its individual pitches (based on a system of extension and contraction of gradually-shifting left-hand positions) to its overall form (in which a constantly-implied strand rises from low on the G string to high on the E). At the same time, the action of the bow is likened to the process of respiration, a process which is under increasing (and eventually terminal) threat of breakdown through the course of the work. The most important aspect of this kind of working, however, is that no distinction is made between the technical and expressive identity of this music (a feature it shares with its darkly-glimpsed antecedents in early baroque violin music). An instrument, after all, is not a 'note-machine' but a means to articulate an 'erotic dialogue between body and intellect' - a phrase used by Mary to characterize her own improvisatory work, itself naturally a crucial influence in shaping the present composition." (BARReTt, R Air. London, United Music Publisher,1994. Também disponivel em http://www.ump.co.uk/Barrett/rb-Air.htm, acesso abril de 2010.)
} 
Na figura 6.12, que corresponde aos compassos 3 e 4, por exemplo, podemos observar que no compasso 3 há dois gestos claros: um gesto com arcada para baixo e dinâmica descrescente de fff para $f$; e um outro gesto com arcada para cima, de menor duração, e com uma dinâmica crescente de $p p p$ a $f$. Nessa inter-relação entre duração, envelope dinâmico e pressão do arco podemos notar algo interessante: há uma semelhança entre a expiração e o movimento para baixo, que está de acordo com a gravidade e com o progressivo relaxamento. Assim como há uma dinâmica sempre mais forte no talão, e uma dinâmica mais suave na ponta do arco. Esse envelope dinâmico é também acompanhado por uma mudança na pressão do arco e do ponto de contato. Por outro lado, se pudéssemos avaliar um valor médio para o envelope dinâmico, ele seria maior nos gestos de expiração do que nos gestos de inspiração. O fato de que os gestos de inspiração possuem, pelo menos a princípio, uma duração menor, acarreta que o arco deve ter uma velocidade maior para contrabalançar a dinâmica e a duração, o que causa uma diferença grande no timbre, como vimos há pouco. Essa diferença vai sendo neutralizada no decorrer da primeira seção, pois há uma tendência muito clara de diminuição da duração nos gestos de expiração, como ilustram as figuras 6.14 e 6.15 .

O ponto de contato do arco também acompanha esse processo. Nos movimentos de arcada para baixo ele percorre o movimento de poco sul ponticello ( $p s p$ ) a molto sul tasto (mst) e de volta a poco sul ponticello. Isso gera necessariamente uma constante movimentação em diagonal. 
Talão (expiração)

Ponta (inspiração)
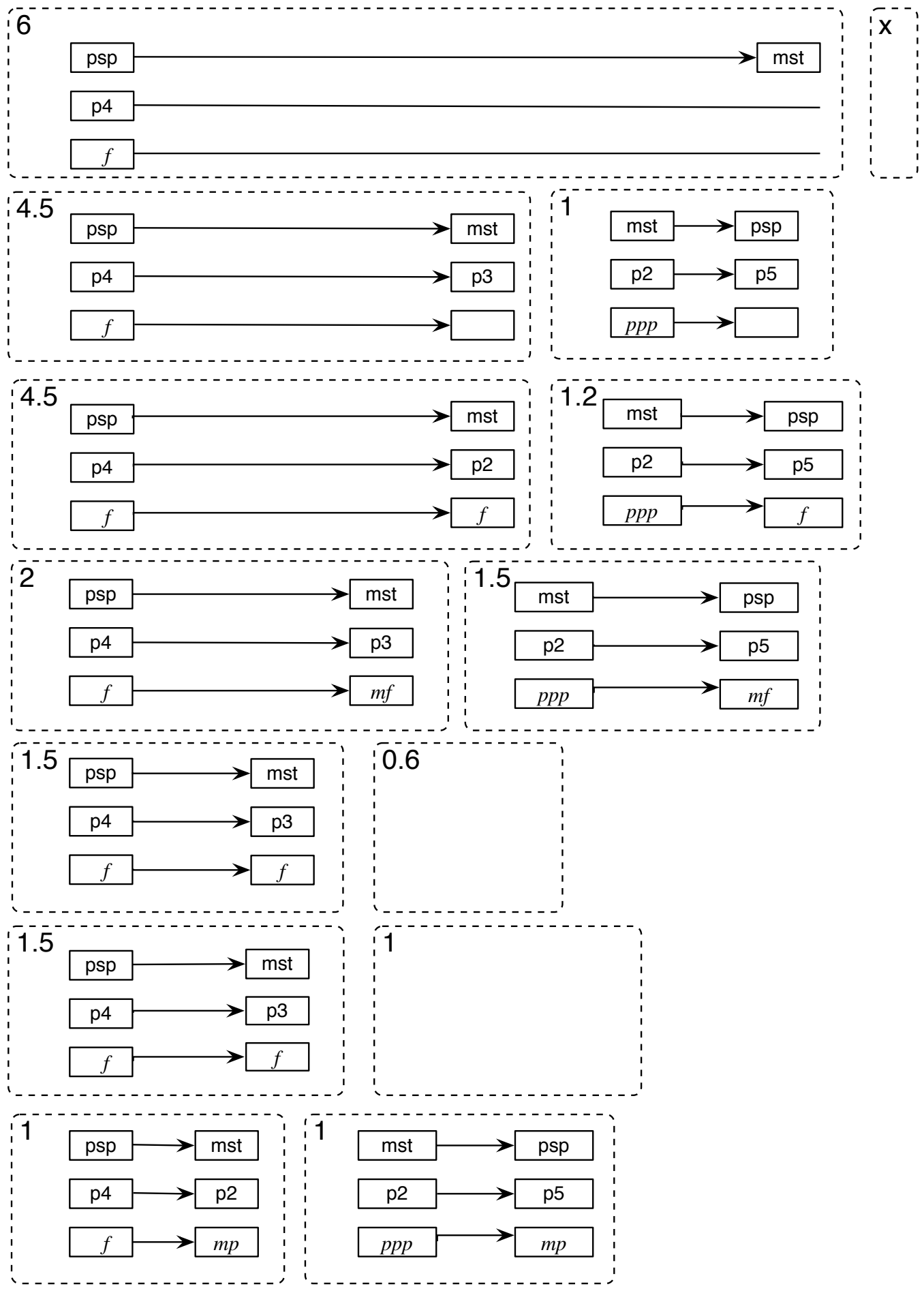

Figura 6.14: Esquema geral de tamanho de frases de parte da primeira seção: dinâmicas, pressão e ponto de contado do arco inspirado na respiração; com inspirações e expirações. 
Esse padrão se repete com variações por toda a primeira seção da obra, e possui uma carga expressiva muito forte que não poderia ser percebida facilmente pela notação, muito menos pelas informações disponíveis apenas através das alturas e ritmos. E de fato poderíamos conceber essa mesma gestualidade e direcionalidade independente das alturas, poderíamos substituí-las e ainda assim grande parte da ideia geral estaria preservada. Mieko Kanno (p.245), que interpretou a referida obra explica que Air "demonstra o poder expressivo das ações de arco prescritivas e a extensão na qual a notação prescritiva do arco pode afetar o resultado dos elementos descritos". Assim como que, do ponto de vista do intérprete, que se depara com a partitura e passa pelo processo de interpretação da notação, "é estranho ver na notação dois conjuntos de indicações simultaneamente: o que já é determinado pela notação (notas) e o que ainda está para ser determinado pela ação (técnica)". Porém em certo ponto, segundo a autora, quando o intérprete de fato absorve o material relativo às camadas prescritivas, ele então percebe que esses elementos não são apenas complementos para as "notas" e os "elementos 'descritos' ", mas representam uma parte essencial do discurso musical.

Então isso, segundo Kanno, gera a grande questão da interpretação: as notas devem ter prioridade de atenção, uma vez que sem elas as técnicas prescritivas não podem ser aplicadas a nada. Pode-se ter a opinião que o poder expressivo das técnicas prescritivas é tão dominante no caso desta peça que as notas são apenas sombras dentro da sua substância. Então, enquanto Air pode quase aparentar ser uma obra de virtuosismo tradicional, sua fascinação verdadeira reside no desafio de impor ao intérprete encontrar uma contextualização apropriada e na destreza do compositor em compor tal arcabouço técnico e expressivo. (p.245) 


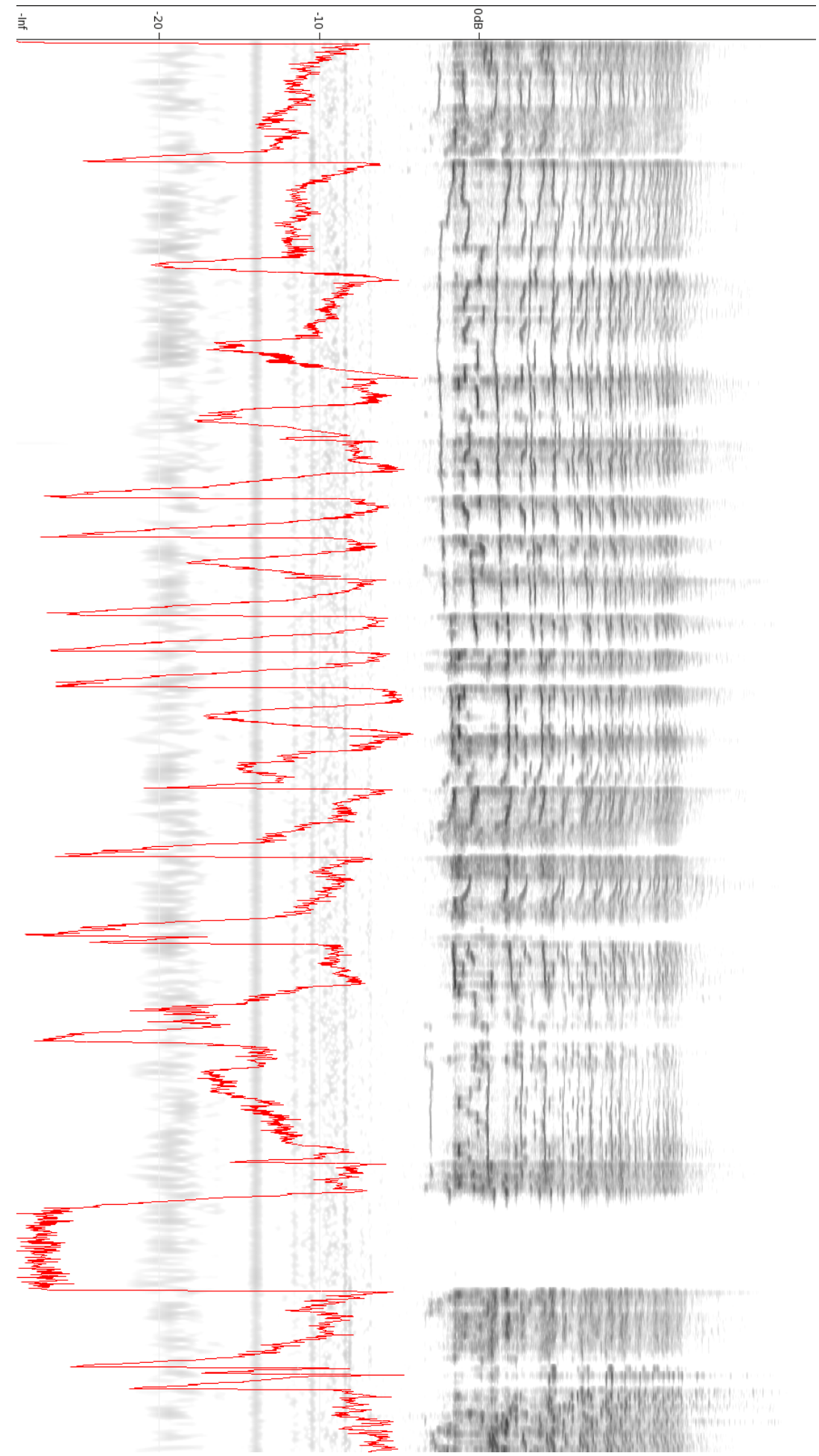

Figura 6.15: Modelo de Respiração, com inspirações e expirações.

\section{Segunda Seção (compassos 20 a 59)}

Na segunda seção há uma confirmação da tendência de ascensão no que diz respeito à altura. Aqui também se introduz novos aspectos figurais que a diferencia da primeira. 
Por exemplo, na primeira seção retomadas de arco no mesmo sentido só ocorrem após uma pausa significativa, já na segunda seção há uma variedade maior dos tipos e tamanhos de frases. Como também há uma quebra com uma certa previsibilidade nas retomadas das frases. Há também a introdução das cordas II e I (que é usada mais raramente nesta seção), de figurações de volata (ver figura 6.16), spiccatos (compassos 20, 23, 49, 58), harmônico, acordes de três notas descendentes (primeira vez no compasso 26) e ascendentes (primeira vez no compasso 27). Nesta seção nota-se, ao contrário da primeira, que há um ganho significativo de velocidade no início e vai gradualmente perdendo energia quando a terceira seção se aproxima.

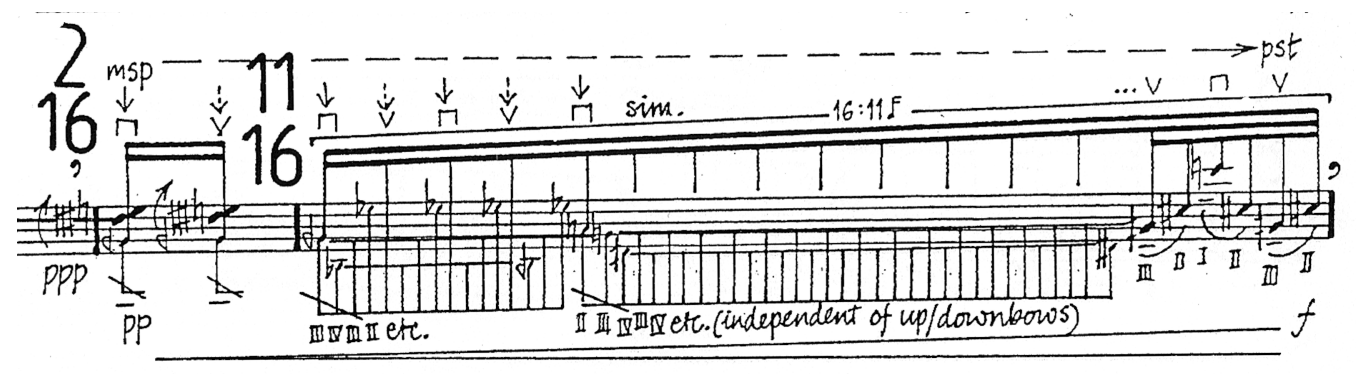

Figura 6.16: Figura de arpejo na segunda seção.

\section{Terceira seção (compassos 60 a 77 )}

Na terceira seção, entre os compassos 60 e 77, também se observa a tendência apresentada na seção anterior de aumento de velocidade procedido de gradual perda de energia. Uma característica marcante nesta seção é a mudança brusca de dinâmica, contrastando frases agressivas com fff tremolo al tallone com muita pressão no arco e molto sul ponticello o que acarreta um som ruidoso, porém com alturas definidas, no compasso 60 (figura 6.17); com frases bem mais suaves como compasso 61, onde a dinâmica vai para ppp e o arco é usado col legno tratto. Algumas dessas passagens mais suaves fazem uma diferenciação interessante, como no compasso 70 onde são escritas utilizando arco normal porém com meio harmônicos, em vez de col legno tratto com pressão do dedo normal. 


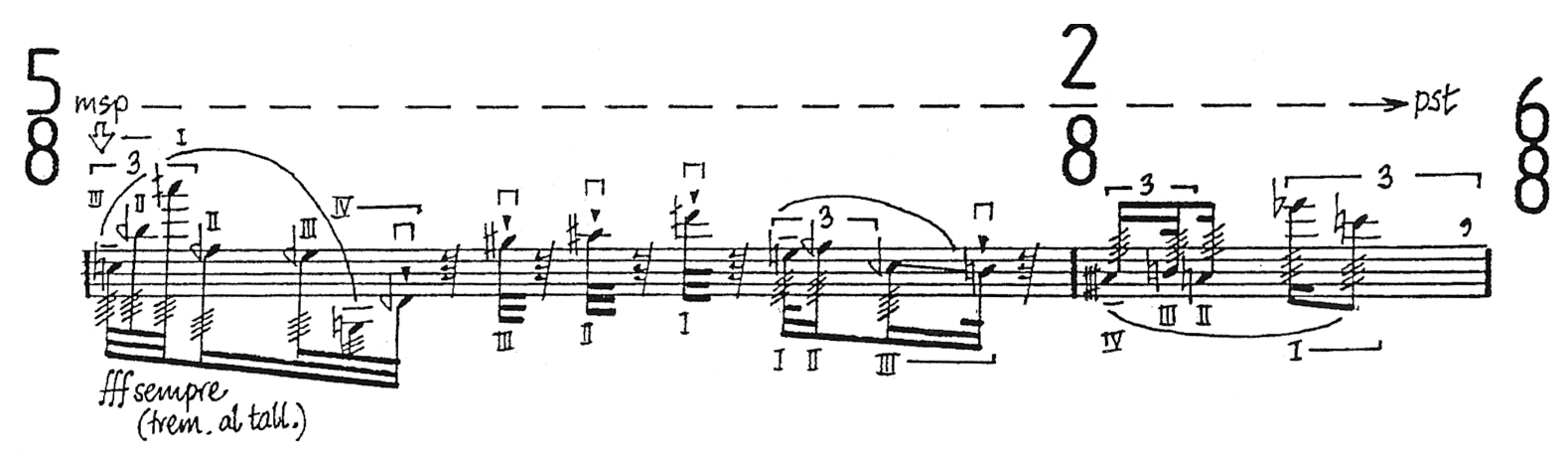

Figura 6.17: Compasso 60.

\section{Quarta seção (compassos 78 a 98 )}

Seguindo a tendência geral da peça da perda gradual de energia, a última seção apresenta uma dinâmica bastante reduzida, quase todas as dinâmicas estão entre $p p$ e p. Como podemos conferir na figura 6.18 o compositor intensifica nessa seção final as diferenciações sutis de timbre através de uma maior atividade, por exemplo, da movimentação do ponto de contato do arco, bem como utiliza largamente as diferenciações entre pressão normal e meio harmônico dos dedos da mão esquerda. Assim como, igualmente seguindo a tendência da peça de utilizar cada vez mais as cordas e as posições mais agudas, o compositor utiliza as cordas $I I$ e $I$ não exclusivamente, mas na maioria absoluta das ações.

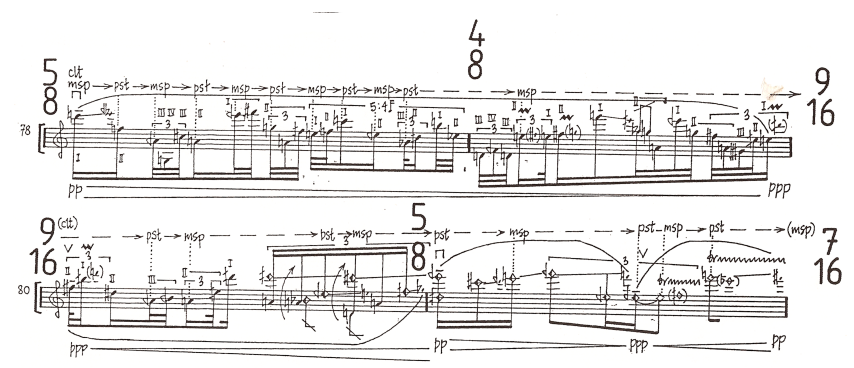

Figura 6.18: Compassos 78 a 81 de Air 


\subsection{A Corporalidade e o Som}

And that's the way I hear that pitch. It's coming to me very slowly, and there's a lot of stuff there.

MORTON FELDMAN

Nas páginas anteriores vimos quão importante é o papel da fisicalidade na construção de Air. Pode-se perceber claramente como a fisicalidade se constitui enquanto um agente ativo na articulação e estruturação da obra, tanto na composição, na interpretação quanto na apreciação musical. Porém devemos ter claro que quando um compositor se concentra no aspecto da fisicalidade isso não significa necessariamente uma atenção em detrimento dos outros aspectos presentes em uma composição musical. Na presente seção tentaremos apontar a relação inseparável de toda a preocupação gestual da obra Air e de uma pesquisa muito sofisticada no que se refere às qualidades internas dos objetos sonoros que a peça articula.

Todos os parâmetros que discutimos anteriormente têm consequências diretas na qualidade dos objetos sonoros em questão. Por exemplo, a pressão do arco tem uma relação direta com a aspereza do timbre de um som. Um som produzido com uma pressão de arco muito alta terá um som sem altura definida, com um espectro muito denso. Do mesmo modo o ponto de contato do arco tem uma consequência direta sobre a presença dos harmônicos superiores em um som. Um som produzido com uma técnica sul ponticello terá uma quantidade muito maior de harmônicos superiores do que um som produzido com uma técnica sul tasto.

Na figura 6.19 podemos observar o efeito causado pela justaposição de duas frases produzidas com técnicas instrumentais diferentes. Trata-se do último compasso da seção 3 e o primeiro compasso da seção 4: compassos 77 e 78 . Apesar da dinâmica, no que se refere à energia requerida para a produção de um som, os dois compassos são produzidos com uma dinâmica entre $p p p$ e $m p$. O compasso 77 é produzido com uma técnica relativamente tradicional, sem vibrato. Já o compasso 78 é produzido 
com a técnica col legno tratto, que cria um objeto sonoro com uma altura muito menos definida e uma dinâmica que não corresponde à energia requerida para a sua produção. Também há uma distorção do movimento do arco que oscila entre molto sul ponticello e poco sul tasto de forma regular, o que gera ainda mais indefinição no que se refere à percepção de alturas definidas. É possível também perceber a diferença no andamento da qualidade do som, no compasso 77, produzido com uma técnica mais próxima da tradicional, percebermos uma homogeneidade maior. Já no compasso 78 percebemos uma variação mais complexa do espectro sonoro, menos definida e mais rica. 


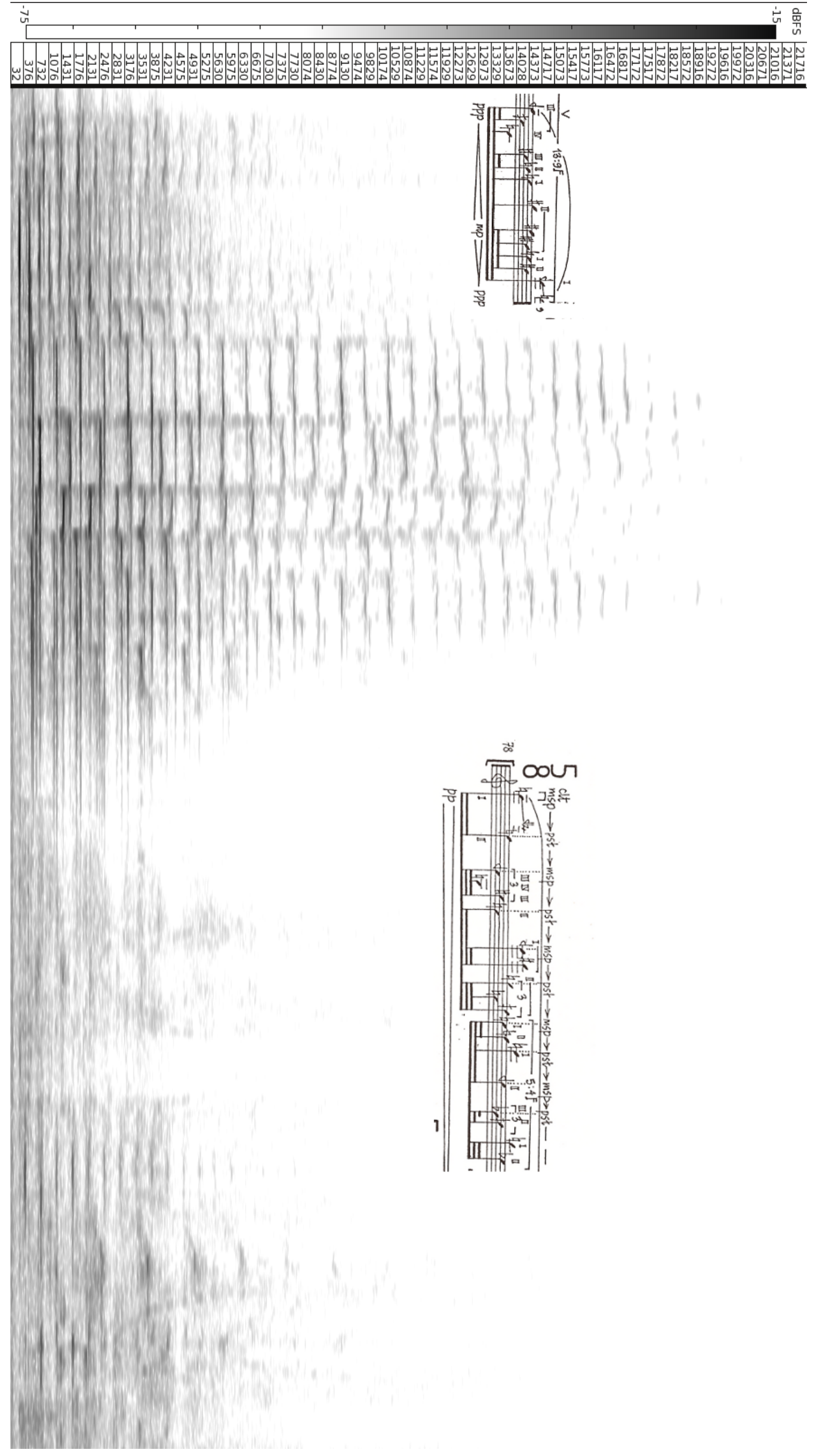

Figura 6.19: Espectrograma e fragmentos correspondentes da partitura, compassos 77 e 78. 
Em outros momentos há uma modelagem do som através das variações não sincronizadas das camadas prescritivas, como podemos observar na figura 6.20 referente ao compasso 22. Nesse compasso há trajetórias não sincronizadas da pressão do arco, da dinâmica, do ponto de contato do arco, da articulação do arco e da pressão do dedo. A trajetória de todos esses parâmetros cria um perfil muito rico do som, transformando o espectro sonoro no tempo. 

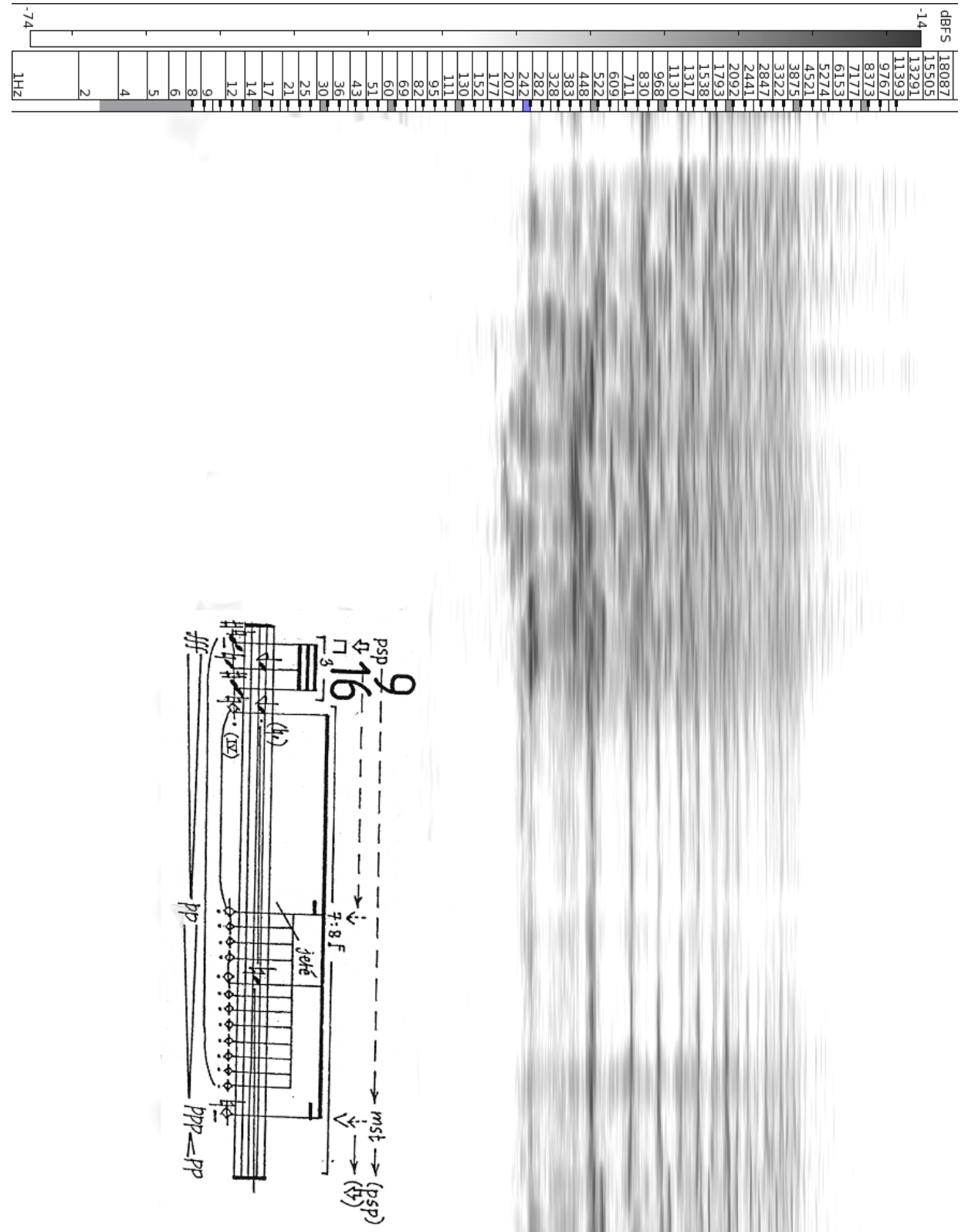

Figura 6.20: Compasso 22 


\subsection{Considerações finais}

Escolhemos a peça Air de Richard Barrett porque acreditamos que ela foi capaz de reunir em um mesmo argumento musical vários temas tratados na pesquisa, como as noções de gesto, corporalidade, polifonia paramétrica e notação prescritiva. Todos esses elementos giram em torno do que poderia ser chamado de "semantificação da técnica instrumental", ou de "corporalidade inteligente"; como querem Wieland Hoban e Frank Cox, respectivamente (Hoban 2002, Cox 2003). O uso da fisicalidade também aqui serviu de inspiração para a construção da própria peça, como o compositor afirmou na nota de programa $9^{9}$ da obra, e como também já mencionamos anteriormente.

${ }^{9}$ Barrett 1994 
Parte III

\section{Conclusão}




\section{Capítulo 7}

\section{Conclusão}

A principal meta a que esta pesquisa se propôs foi revelar da melhor maneira o papel que a corporalidade realiza tanto nas obras do repertório tradicional quanto, e principalmente, na música contemporânea, além de todos os desenvolvimentos potenciais que ela representa para novas explorações no campo da criação musical. Tentamos esclarecer de maneira sistemática como a corporalidade está, de fato, presente em todo o repertório, assim como em obras de compositores que notoriamente utilizaram a fisicalidade como principal elemento estrutural da composição, a exemplo de Helmut Lachenmann, Klaus K. Hübler, Richard Barrett e, mais recentemente, Aaron Cassidy.

Por meio da pesquisa realizada neste trabalho pudemos comprovar, embasar, fundamentar e pontuar com exemplos concretos nossas ideias sobre a importância da corporalidade e do gesto como elemento morfológico fundamental da composição. O ponto de partida foi uma percepção pessoal da importância da inter-relação entre áreas que normalmente são vistas de forma desintegrada: as relações entre corpo, mente, gesto, movimento, estruturação composicional, interpretação, notação musical. Todas essas referências inter-relacionadas nos pareceu ter um futuro promissor no sentido de gerar uma nova qualidade a ser estudada no âmbito musical, onde as questões pudessem ser discutidas mais amplamente e de maneira mais interativa.

O compositor e teórico Brian Ferneyhough fez uma grande contribuição para o aguçamento da percepção da noção de gesto (ou "figura") no contexto da música contem- 
porânea, ainda que a palavra gesto já fosse parte do vocabulário comum tratando-se de articulação musical. Ferneyhough faz uma diferenciação sobre o que ele chama "figura" , que seria um gesto com propriedades de construção e desconstrução, e o que ele chama de "gesto". O compositor apontou estas possibilidades de elaboração do gesto, o que nos permitiu pensar que um gesto pode ser decomposto em instâncias menores (por exemplo: um perfil de alturas, um envelope de dinâmica, a evolução de um parâmetro físico da técnica instrumental no tempo etc.), o que nos permite ter uma visão mais detalhada do gesto ao mesmo tempo que o projeta através dessa construção, desconstrução e reconstrução, para a formação de novos gestos no discurso musical. Esta proposta de desconstruir o gesto para poder enxergar as diversas partes que o compõe tanto nos permite entender o "interior" do mesmo quanto nos inspirou a pesquisar mais profundamente quais os possíveis componentes que interferem, estimulam e colaboram com a relação entre o corpo, o gesto e a criação musical. Desta maneira, pudemos observar que, um fator normalmente desprezado ou visto como secundário - a corporalidade — é um componente importantíssimo do gesto musical, que dependendo do contexto, está em pé de igualdade com outros parâmetros, como alturas e durações, como vimos no capítulo 6, quanto tratamos da obra de Richard Barrett.

Compositores como Helmut Lachenmann e Klaus K. Hübler foram também, cada um a seu modo, importantes para a sensibilização do potencial expressivo da corporalidade na produção da música contemporânea. Helmut Lachenmann foi o primeiro compositor a, de fato, desmantelar a técnica instrumental na estrutura e na escrita da composição e utilizar tais componentes e camadas de material de forma independente e inter-relacionada. Klaus K. Hübler pertence a uma geração posterior e possui uma orientação estética bastante diversa de Lachenmann, porém sobre este questão do desmantelamento e elaboração dos parâmetros físicos na composição ele foi o primeiro grande exemplo de radicalização nesse sentido. Posteriormente outros compositores também sofreram influência neste ponto e também se sensibilizaram para esse aspecto da composição, em ordem cronológica, Richard Barrett, Frank Cox e Aaron Cassidy. 
Algo muito interessante também foi a contribuição teórica por parte de intérpretes do repertório contemporâneo, como Mieko Kanno. Seu artigo sobre a notação prescritiva foi de um valor inestimável (Kanno 2007), não só por sua abordagem original e sofisticada do tema, mas pelo próprio ponto de vista de uma pessoa que trabalha com a interpretação desse repertório.

Do nosso ponto de vista, as características abordadas neste trabalho não constituem, de nenhum modo, conclusões finais sobre esses temas. Entendemos como uma tentativa de refletir sobre tendências que acreditamos ser esteticamente relevantes que acontecem na História da Música recente e que possuem potencial para inúmeras novas tentativas de reflexão e produção criativa, tanto por parte de intérpretes quanto por parte de compositores. 


\section{Referências Bibliográficas}

[Adorno 2002]ADORNO, T. Essays on Music. Berkeley: University of California Press, 2002. ISBN 9780520231597.

[Adorno 2006]ADORNO, T. Philosophy of New Music. Minneapolis: University of Minnesota Press, 2006. ISBN 9-780816-636662.

[Adorno 1998]ADORNO, T. W. Quasi Una Fantasia: Essays on Modern Music. London: Verso, 1998. ISBN 1859841597.

[Alberman 2005]ALBERMAN, D. Abnormal playing techniques in the string quartets of Helmut Lachenmann. Contemporary Music Review, v. 24, p. 39-51, 2005.

[André 2004]ANDRÉ, M. Computer-assisted musical composition and creation of a compositional model. In: MAHNKOPF, C. (Ed.). The Foundations of contemporary composition. Hofheim: Wolke, 2004. ISBN 9783936000146.

[Andriessen 2006]ANDRIESSEN, L. Louis Andriessen. Contemporary Music Review, v. 25, n. 5/6, p. 541-548, 2006. ISSN 0749-4467.

[Apel e Binkley 1990]APEL, W.; BINKLEY, T. Italian violin music of the seventeenth century. [S.l.]: Indiana University Press, 1990. 332 p. ISBN 9780253306838.

[Barrett 1986]BARRETT, R. anatomy. Essex: Uniter Music Publishers Ltd., 1986. Partitura; 11 instrumentos.

[Barrett 1988]BARRETT, R. ne songe plus à fluir. Essex: United Music Publishers Ltd., 1988. Partitura; violoncelo amplificado. 
[Barrett 1993]BARRETT, R. knospend-gespaltener. Essex: United Music Publishers Ltd., 1993. Partitura; clarineta em dó.

[Barrett 1994]BARRETT, R. air. Essex: United Music Publisher Ltd., 1994. Partitura; violino. ISMN M2244-0668-5.

[Barrett 1997]BARRETT, R. Opening of the Mouth. Essex: United Music Publishers Ltd., 1997. Partitura; vozes, grupo instrumental e eletrônica. ISMN M-2244-0160.

[Barrett 1998]BARRETT, R. Not necessarily anything to do with Karlheinz Stockhausen. Leonardo Music Journal, v. 8, p. 17-19, 1998. ISSN 09611215.

[Barrett 1998]BARRETT, R. Tracts for our times? The Musical Times, v. 139, n. 1864, p. 21-24, 1998. ISSN 00274666.

[Benade 1994]BENADE, A. H. Woodwinds: The evolutionary path since 1700. The Galpin Society Journal, v. 47, p. 63-110, mar. 1994. ISSN 00720127.

[Bent 1986]BENT, I. Heinrich schenker, Chopin and Domenico Scarlatti. Music Analysis, v. 5, n. 2/3, p. 131-149, out. 1986. ISSN 02625245.

[Bergson 2006]BERGSON, H. O Pensamento e o Movente. São Paulo: Martins Fontes, 2006. ISBN 8533622295, 9788533622296.

[Böhm 1964]BÖHM, T. The flute and flute-playing in acoustical, technical, and artistic aspects. New York: Dover Publications, 1964. ISBN 9780486212593.

[Bouissou 2005]BOUISSOU, S. La notation musicale aux époques baroque et classique. In: BOUISSOU, S.; GOUBAULT, C.; BOSSEUR, J.-Y. (Ed.). Histoire de la notation de l'époque baroque à nos jours. Paris: Minerve, 2005.

[1]BOUISSOU, S.; GOUBAULT, C.; BOSSUER, J.-Y. Histoire de la notation de l'époque baroque à nous jours. Paris: Minerve, 2005. ISBN 2-86931-112-5. 
[Boulez 2005]BOUlEZ, P. Leçons de Musique. Points de Repère III: deux décennies d'enseignement au Collège de France (1976-1995). Paris: Cristian Bourgois Éditeur, 2005. ISBN 2.267.01757-1.

[Brougham et al. 1997]BROUGHAM, H. et al. Uncommon Ground : the music of Michael Finnissy. Aldershot: Ashgate, 1997. ISBN 9781859283561.

[Carter 1991]CARTER, S. The String Tremolo in the 17th Century. Early Music, v. 19, n. 1, p. 43-59, 1991. ISSN 03061078.

[Cassidy 2002]CASSIDY, A. Interconnectivity and abstraction: 'Metallic dust' as testing ground for monophonic and structural polyphonies. In: MAHNKOPF, C.; COX, F.; SCHURIG, W. (Ed.). Polyphony $\&$ complexity. Hofheim: Wolke, 2002. p. 147-161. ISBN 9783936000108.

[Cassidy 2004]CASSIDY, A. Performance Physicality and Choreography as Morphological Determinants. In: MAHNKOPF, C.; COX, F.; SCHURIG, W. (Ed.). Musical morphology. Hofheim: Wolke, 2004. ISBN 9783936000139.

[Cassidy 2008]CASSIDY, A. Determinate Action / Indeterminate Sound: tablature and chance in several recent works. In: MAHNKOPF, C.; COX, F.; SCHURIG, W. (Ed.). Facets of the Second Modernity. Hofheim: Wolke, 2008. ISBN 9783936000177.

[Claren 2004]CLAREN, S. Construction and Conceptuality. In: MAHNKOPF, C. (Ed.). The Foundations of Contemporary Composition. Hofheim: Wolke, 2004. ISBN 9783936000146.

[Cox 2002]COX, F. Notes toward a Performance Practice for Complex Music. In: MAHNKOPF, C.; COX, F.; SCHURIG, W. (Ed.). Polyphony \& Complexity. Hofheim: Wolke, 2002. p. 70-132. ISBN 9783936000108.

[Cox 2003]COX, F. Toward an Intelligent Corporality: the Virtual Body. In: MAHNKOPF, C.; Pagh-Paan, Y. (Ed.). ars (in)humana? Bremem: Einwurf, 2003. 
[Cox 2004]COX, F. Musical progress? new music and perils of progressivist historicism. In: MAHNKOPF, C. (Ed.). The Foundations of contemporary composition. Hofheim: Wolke, 2004. ISBN 9783936000146.

[Cox 2005]COX, F. Helmut lachenmann als romantischer Hochmodernist. In: JAHN, H. (Ed.). Helmut Lachenmann - auf(-) und zuhören: 14 essaistische Reflexionen über die Musik und die Person Helmut Lachenmann. Hofheim: Wolke Verlag, 2005.

[Cox 2006]COX, F. Critical Modernism: beyound critical composition and uncritical art. In: MAHNKOPF, C. (Ed.). Critical composition today. Hofheim: Wolke Verlag, 2006. ISBN 9783936000160.

[Cox 2008]COX, F. Recoil, fof solo cello: Backgrounds and analysis. In: MAHNKOPF, C.; COX, F.; SCHURIG, W. (Ed.). Facets of the Second Modernity. Hofheim: Wolke, 2008. ISBN 9783936000177.

[Cunliffe 2001]CUNLIFFE, L. After late- and postmodernism: A wittgensteinian reconstructive and transformative aesthetics, art practice, and art education. Journal of Aesthetic Education, v. 35, n. 3, p. 1-13, 2001. ISSN 00218510.

[Dahlhaus 1983]DAHLHAUS, C. Foundations of Music History. Cambridge [Cambridgeshire] ;;New York: Cambridge University Press, 1983. ISBN 9780521232814.

[Dahlhaus 1991]DAHLHAUS, C. The idea of absolute music. Pbk. Chicago: University of Chicago Press, 1991. ISBN 9780226134871.

[Dale 1947]DALE, K. Domenico Scarlatti: his Unique Contribution to Keyboard Literature. Proceedings of the Royal Musical Association, v. 74, p. 33-44, 1947. ISSN 00804452.

[Dann 1968]DANN, E. Heinrich Biber and the Seventeenth Century Violin. 419 p. Tese (Doutorado) - Columbia University, New York, 1968. 
[Delalande 1988]DELALANDE, F. La gestique de Gould: élements pour une sémiologie du geste musical. In: Gleen Gould Pluriel. [S.l.]: Louise Courteau, 1988.

[Deleuze 2003]DELEUZE, G. Francis Bacon: lógica da sensação. Rio de Janeiro: Jorge Zahar, 2003. ISBN 8537800252, 9788537800256.

[Dench 2002]DENCH, C. Complexity and Polyphony. In: MAHNKOPF, C.; COX, F.; SCHURIG, W. (Ed.). Polyphony \&6 Complexity. Hofheim: Wolke, 2002. p. 147-161. ISBN 9783936000108.

[Descartes 2005]DESCARTES, R. Meditações Metafísicas. São Paulo: Martins Fontes, 2005. ISBN 8533621183.

[Dreyfus 1990]DREYFUS, H. L. Being-in-the-World: a commentary on Heidegger's being and time, Division I. Cambridge, Massachusetts: The MIT Press, 1990. ISBN 0262540568 .

[Dreyfus 1992]DREYFUS, H. L. What Computers Still Can't Do: A Critique of Artificial Reason. Cambridge, Massachusetts: The MIT Press, 1992. ISBN 0262540673.

[Dreyfus e Dreyfus 1986]DREYFUS, H. L.; DREYFUS, S. E. Mind over machine: The power of human intuition and expertise in the era of the computer. First edition. New York: Free Press, 1986. ISBN 0029080606.

[Feldman 1985]FELDMAN, M. Essays. Beginner press. Kerpen: Beginner Press, 1985.

[Ferneyhough 1993]FERNEYHOUGH, B. Il tempo della figura. Perspectives of New Music, v. 31, n. 1, 1993. ISSN 00316016.

[Ferneyhough 1995]FERNEYHOUGH, B. Collected Writings. 1. ed. Amsterdam: Routledge, 1995. ISBN 3718655772.

[Ferneyhough 1999]FERNEYHOUGH, B. Ferneyhough, Brian. In: SZENDY, P. (Ed.). Brian Ferneyhough. Paris; Montrèal: Harmattan \& Centre Ircam-Centre GeorgesPompidou, 1999. ISBN 9782738478788. 
[Ferneyhough 1999]FERNEYHOUGH, B. La 'musique informelle' (à partir d'une lecture d'Adorno). In: SZENDY, P. (Ed.). Brian Ferneyhough. Paris; Montrèal (Québec): Harmattan; Centre Ircam-Centre Georges-Pompidou, 1999. ISBN 9782738478788.

[Ferneyhough 2005]FERNEYHOUGH, B. Barbarians at the Gates. KunstMusik : Schriften zur Musik als Kunst, v. 4, p. 26-34, 2005. ISSN 16126173.

[Ferneyhough 2009]FERNEYHOUGH, B. Adorno Presentation. mar. 2009. Página da Web. Disponível em: $<$ http://www.entretemps.asso.fr/Adorno/Informel/Ferneyhough.htm>.

[Ferneyhough et al. 2008]FERNEYHOUGH, B. et al. An interview with Brian Ferneyhough. 2008. Disponível em: <http://www.searchnewmusic.org>.

[Ferneyhough et al. 2009]FERNEYHOUGH, B. et al. Entrevista com Brian Ferneyhough. Revista do Conservatório de Música de UFPel, n. 2, p. 1-18, 2009. ISSN 1984-350X.

[Ferneyhough e Sheridan 2009]FERNEYHOUGH, B.; SHERIDAN, M. In conversation with Brian Ferneyhough. jun. 2009. Disponível em: $<$ http://newmusicbox.org/page.nmbx?id=4344>.

[Ferneyhough e Toop 1995]FERNEYHOUGH, B.; TOOP, R. Interview. In: Collected Writings. 1. ed. Amsterdam: Routledge, 1995. p. 3-13. ISBN 3718655772.

[Flammer 2006]FLAMMER, E. H. A critique of negativism: Possibilities and limits of an aesthetic of 'musica negativa'. In: MAHNKOPF, C. (Ed.). Critical Composition Today. Hofheim: Wolke Verlag, 2006. ISBN 9783936000160.

[Fox 2002]FOX, C. Michael Finnissy's History of Photography in Sound: under the lens. The Musical Times, v. 143, n. 1879, p. 26-35, 2002. ISSN 00274666. Disponível em: <http://www.jstor.org/stable/1004595>. 
[Godøy e Leman 2009]GODØY, R. I.; LEMAN, M. Musical Gestures: Sound, Movement, and Meaning. 1. ed. [S.l.]: Routledge, 2009. ISBN 0415998875.

[Grasse 2007]GRASSE, T. Heinrich Ignaz Franz Biber(1644-1704)- hintergründe zu den Rosenkranz-Sonaten. [S.l.]: GRIN Verlag, 2007. 45 p. ISBN 9783638778749.

[Grella-Mozdotejko 2005]Grella-Mozdotejko, P. Helmut Lachenmann-Style, sound, text. Contemporary Music Review, v. 24, p. 57-75, 2005. Disponível em: <http://dx.doi.org/10.1080/0749446042000293619>.

[Gritten e King 2006]GRITTEN, A.; KING, E. Music and Gesture. Burlington: Ashgate Publishing, 2006. ISBN 075465298X.

[Harvey 1975]HARVEY, J. The music of Stockhausen. Berkley: University of California Press, 1975. 142 p. ISBN 9780520023116.

[Heijink e Meulenbroek 2002]HEIJINK, H.; MEULENBROEK, R. G. On the complexity of classical guitar playing: functional adaptations to task constraints. Journal of motor behavior, v. 34, n. 4, p. 339-352, 2002.

[Hindrichs 2004]HINDRICHS, G. Musical modernity: What does it mean today? In: MAHNKOPF, C. (Ed.). The Foundations of contemporary composition. Hofheim: Wolke, 2004. ISBN 9783936000146.

[Hoban 2002]HOBAN, W. Towards the Semantification of Instrumental Technique. In: MAHNKOPF, C.; COX, F.; SCHURIG, W. (Ed.). Polyphony $\&$ complexity. Hofheim: Wolke, 2002. p. 147-161. ISBN 9783936000108.

[Hoban 2004]HOBAN, W. Morphological boundaries and their dissolution: Hedone for string quintet. In: MAHNKOPF, C.; COX, F.; SCHURIG, W. (Ed.). Musical morphology. Hofheim: Wolke, 2004. ISBN 9783936000139. 
[Hoban 2004]HOBAN, W. On the methodology and aesthetics of form polyphony. In: MAHNKOPF, C. (Ed.). The Foundations of contemporary composition. Hofheim: Wolke, 2004. ISBN 9783936000146.

[Hoban 2004]HOBAN, W. On the Methodology and Aesthetics of Form-Polyphony. In: MAHNKOPF, C.-S. (Ed.). The Foundations of Contemporary Composing. Hofheim: Wolke Verlag, 2004. ISBN 3-936000-14-X.

[Hoban 2005]HOBAN, W. Zur Musik Klaus K. Hüblers. Saarbruecken: Pfau-Vlg, 2005. ISBN 3897272687.

[Hockings 2005]HOCKINGS, E. All dressed up and nowhere to go. Contemporary Music Review, v. 24, p. 89-100, fev. 2005. Disponível em: <http://www.ingentaconnect.com/content/routledg/gcmr/2005/00000024/00000001/art00009>.

[Hübler 1984]HÜBLER, K. K. Expanding the String Technique. Interface, v. 13, n. 4, p. 187, 1984. ISSN 0303-3902. Disponível em: $<$ http://www.informaworld.com/10.1080/09298218408570452>.

[Hübler 1985]HÜBLER, K. K. 3. Streichquartett: Dialektische Fantasie (1982-84). Wiesbaden: Breitkopf \& Härtel, 1985. Partitura; quarteto de cordas.

[Hübler 1987]HÜBLER, K. K. Sonetto LXXXIII del Michelangelo (1986). Wiesbaden: Breitkopf \& Härtel, 1987. Partitura; piano. ISMN: M 004178904.

[Hübler 2004]HÜBLER, K. K. Expanding String Technique. In: MAHNKOPF, C.; COX, F.; SCHURIG, W. (Ed.). Musical morphology. Hofheim: Wolke, 2004. ISBN 9783936000139 .

[Huron e Berec 2009]HURON, D.; BEREC, J. Characterizing idiomatic organization in music: A theory and case study of musical affordances. Empirical Musicology Review, v. 4, 2009. 
[Jahn-Bossert 2005]Jahn-Bossert, H. Fear of... essayistic miniatures on Grido. Contemporary Music Review, v. 24, p. 31-38, fev. 2005. Disponível em: <http://www.ingentaconnect.com/content/routledg/gcmr/2005/00000024/00000001/art00003>.

[Jerkert 2003]JERKERT, J. Measurements and models of musical articulation. In: Proceedings of SMAC03 (Stockholm Music Acoustics Conference 2003). [S.l.: s.n.], 2003. p. $537-541$.

[Kanno 2007]KANNO, M. Prescriptive Notation: limits and challenges. Contemporary Music Review, v. 26, p. 231-254, abr. 2007. Disponível em: <http://www.ingentaconnect.com/content/routledg/gcmr/2007/00000026/00000002/art00009>.

[Knepler 1977]KNEPLER, G. Geschichte als Weg zum Musikverständnis. Leipzig: Verlag Philipp Reclam, 1977.

[Lachenmann 1972]LACHENMANN, H. Gran Torso: Musik für Streichquartett. Wiesbaden: Breitkopf \& Haertel, 1972. Partitura; quarteto de cordas.

[Lachenmann 1980]LACHENMANN, H. The 'Beautiful' in music today. Tempo, n. 135, p. 20-24, dez. 1980. ISSN 00402982. Disponível em: $<$ http://www.jstor.org/stable/946043>.

[Lachenmann 1982]LACHENMANN, H. Kontrakadenz. Wiesbaden: Breitkopf \& Härtel, 1982. Partitura; orquestra.

[Lachenmann 1982]LACHENMANN, H. Kontrakadenz (1970-71). Wiesbaden: Breitkopf \& Härtel, 1982. Partitura; grande orquestra.

[Lachenmann 1985]LACHENMANN, H. Mouvement (-vor der Erstarrung). Wiesbaden: Breitkopf \& Härtel, 1985. Partitura; grupo instrumental.

[Lachenmann 1989]LACHENMANN, H. II. Streichquartett 'Reigen seliger Geister'. Wiesbaden: Breitkopf \& Härtel, 1989. Partitura; quarteto de cordas. ISMN M 00450182 5. 
[Lachenmann 1999]LACHENMANN, H. Touched by Nono. Contemporary Music Review, v. 18, p. 17-30, 1999.

[Lachenmann 2002]LACHENMANN, H. III. Streichquartett 'Grido"(Fassung Oktober 2002). Wiesbaden: Breitkopf \& Härtel, 2002. Partitura; quarteto de cordas.

[Lachenmann 2002]LACHENMANN, H. "..zwei Gefühle...", Musik mit Leonardo (1992). Wiesbaden: Breitkopf \& Härtel, 2002. Partitura; para locutores e grupo instrumental. ISMN M-004-21091-8.

[Lachenmann 2004]LACHENMANN, H. Composing in the Shadow of Darmstadt. Contemporary Music Review, v. 23, p. 43-53, 2004. Disponível em: <http://www.ingentaconnect.com/content/routledg/gcmr/2004/00000023/F0020003/art00015>.

[Lachenmann 2004]LACHENMANN, H. Four questions regarding new music. Contemporary Music Review, v. 23, p. 55-57, 2004.

[Lachenmann 2004]LACHENMANN, H. Musik als existentielle Erfahrung : Schriften 1966-1995. Wiesbaden: Breitkopf \& Härtel, 2004. ISBN 9783765102479.

[Lachenmann 2004]LACHENMANN, H. On my Second String Quartet (Reigen seliger Geister). Contemporary Music Review, v. 23, p. 59-79, 2004.

[Lachenmann 2005]LACHENMANN, H. Philosophy of composition - is there such a thing? In: Identity and difference : essays on music, language, and time. Leuven: Leuven University Press, 2005. p. 55-70. ISBN 9789058674135.

[Lachenmann 2009]LACHENMANN, H. "musique concrète instrumentale": Helmut Lachenmann, in conversation with Gene Coleman. 2009. Disponível em: $<$ http://slought.org/content/11401/>.

[Lehmann 2006]LEHMANN, H. Avant-garde today: A theoretical model of aesthetic modernity. In: MAHNKOPF, C. (Ed.). Critical composition today. Hofheim: Wolke Verlag, 2006. ISBN 9783936000160. 
[Leman 2007]LEMAN, M. Embodied Music Cognition and Mediation Technology. 1. ed. Cambridge, Mass.: The MIT Press, 2007. ISBN 0262122936.

[Leppert 1995]LEPPERT, R. The Sight of Sound: Music, Representation, and the History of the Body. [S.l.]: University of California Press, 1995. ISBN 0520203429.

[Luhmann 2000]LUHMANN, N. Art as a Social System. Stanford Calif.: Stanford University Press, 2000. ISBN 9780804739061.

[MacGillivray 1959]MacGillivray, J. A. Recent advances in woodwind fingering systems. The Galpin Society Journal, v. 12, p. 68-72, maio 1959. ISSN 00720127.

[Mahnkopf 2004]MAHNKOPF, C. On Musical Deconstruction. In: MAHNKOPF, C.; COX, F.; SCHURIG, W. (Ed.). Musical morphology. Hofheim: Wolke, 2004. ISBN 9783936000139.

[Mahnkopf 2002]MAHNKOPF, C.-S. Theory of Polyphony. In: MAHNKOPF, C.-S.; COX, F.; SCHURIG, W. (Ed.). Polyphony \& Complexity. Hofheim: Wolke Verlag, 2002. ISBN 3-936000-10-7.

[Merleau-Ponty 2002]MERLEAU-PONTY, M. Phenomenology of Perception. London: Routledge, 2002. 584 p. ISBN 9780415278416.

[Merleau-Ponty 2008]MERLEAU-PONTY, M. The World of Perception. 1. ed. London: Routledge, 2008. ISBN 0415773814.

[Noë 2004]NOË, A. Action in Perception. Cambridge, Mass.: The MIT Press, 2004. ISBN 978-0-262-14088-1.

[Nonnenmann 2005]NONNENMANN, R. Music with images: the development of Helmut Lachenmann's Sound Composition between Concretion and Transcendence. Contemporary Music Review, v. 24, n. 1, p. 1, 2005. ISSN 0749-4467. 
[Nonnenmann 2006]NONNENMANN, R. The dead end as a way out. Critical composition: a historical phenomenon? In: MAHNKOPF, C. (Ed.). Critical composition today. Hofheim: Wolke Verlag, 2006. ISBN 9783936000160.

[Pace 1996]PACE, I. The Panorama of Michael Finnissy (I). Tempo, n. 196, p. 25-35, abr. 1996. ISSN 00402982.

[Pace 1997]PACE, I. The panorama of Michael Finnissy (II). Tempo, n. 201, p. 7-16, jul. 1997. ISSN 00402982. Disponível em: < http://www.jstor.org/stable/944689>.

[Pace 1998]PACE, I. Positive or Negative 1. The Musical Times, v. 139, n. 1859, p. 9-17, 1998. ISSN 00274666. Disponível em: <http://www.jstor.org/stable/1003769>.

[Pace 1998]PACE, I. Positive or negative 2. The Musical Times, v. 139, n. 1860, p. 4-15, fev. 1998. ISSN 00274666.

[Parker 1992]PARKER, E. De Motu. 1992. Http://www.efi.group.shef.ac.uk/fulltext/demotu.html. Disponível em: <http://www.efi.group.shef.ac.uk/fulltext/demotu.html>.

[Parncutt et al. 1997]PARNCUTT, R. et al. An ergonomic model of keyboard fingering for melodic fragments. Music Perception, v. 14, n. 4, p. 341-382, 1997.

[Pauset 2008]PAUSET, B. The Impossible and its Methods. In: MAHNKOPF, C.; COX, F.; SCHURIG, W. (Ed.). Facets of the Second Modernity. Hofheim: Wolke, 2008. ISBN 9783936000177.

[Pierce 2010]PIERCE, A. Deepening Musical Performance through Movement: the theory and practice of embodied interpretation. 1. ed. Bloomington and Indianapolis: Indiana University Press, 2010. ISBN 0253222230.

[Radicioni e Lombardo 2007]RADICIONI, D.; LOMBARDO, V. A constraint-based approach for annotating music scores with gestural information. Constraints, v. 12, n. 4, p. 405-428, dez. 2007. Disponível em: <http://dx.doi.org/10.1007/s10601-007-9015$\mathrm{y}>$. 
[Redgate 2001]REDGATE, R. Brian Ferneyhough's 'Etudes Transcendantales'. Contemporary Music Review, v. 20, p. 79-100, 2001.

[Ridley 1986]RIDLEY, E. A. K. Birth of the 'Boehm' clarinet. The Galpin Society Journal, v. 39, p. 68-76, set. 1986. ISSN 00720127.

[Robert 2005]ROBERT, M. Ivo Malec et son Studio Instrumental. Paris: L'Harmattan, 2005. ISBN 9782747585927.

[Rosen 1998]ROSEN, C. The Romantic Generation. 1st. ed. Cambridge Mass.: Harvard University Press, 1998. ISBN 9780674779341.

[Ruzicka 2004]RUZICKA, P. Toward a New Aesthetic Quality, On Helmut Lachenmanns Aesthetics of Material. Contemporary Music Review, v. 23, p. 97-102, 2004. Disponível em: <http://www.ingentaconnect.com/content/routledg/gcmr/2004/00000023/F0020003/art00021>.

[Sachs 2006]SACHS, C. The History of Musical Instruments. Mineola N.Y.: Dover Publications, 2006. ISBN 9780486452654.

[Sani 2004]SANI, N. Musical thought and technology: Composing by means of the present. In: MAHNKOPF, C. (Ed.). The Foundations of contemporary composition. Hofheim: Wolke, 2004. ISBN 9783936000146.

[Sankey 2009]SANKEY, J. Why yet another Scarlatti Edition? jan. 2009. Disponível em: <http://www.johnsankey.ca/scarlattimus.html>.

[Schneider 2010]SCHNEIDER, A. Music and gestures: a historical introduction and survey of earlier reserach. In: Musical Gestures: sound, movement and meaning. New York: Routledge, 2010.

[Schurig 2002]SCHURIG, W. The figure and its dramaturgy. In: MAHNKOPF, C.; COX, F.; SCHURIG, W. (Ed.). Polyphony $\&$ complexity. Hofheim: Wolke, 2002. p. 147-161. ISBN 9783936000108. 
[Searle 2003]SEARLE, J. Minds, Brains and Science. 13. ed. Cambridge, Massachusetts: Havard University Press, 2003.

[Searle 1970]SEARLE, J. R. Speech Acts. Cambridge, Massachusetts: Cambridge University Press, 1970. 216 p. ISBN 052109626X, 9780521096263.

[Searle 1983]SEARLE, J. R. Intentionality: an essay in the Philosophy of Mind. Cambridge, Massachusetts: Cambridge University Press, 1983. ISBN 0521273021.

[Searle 1992]SEARLE, J. R. The Rediscovery of the Mind. Cambridge, Massachusetts: The MIT Press, 1992. ISBN 026269154X.

[Searle 2000]SEARLE, J. R. Consciousness. Annual Review of Neuroscience, v. 23, p. 557-578, 2000. ISSN 0147-006X. PMID: 10845075. Disponível em: <http://www.ncbi.nlm.nih.gov/pubmed/10845075>.

[Shepherd 1995]SHEPHERD, R. C. The emergence of a pivotal role for the thumb in keyboard fingering during the early eighteenth century and its subsequent impact on pianistic idiom. Tese (Doutorado) - University of Illinois at Urbana-Champaign, 1995.

[Shove e Repp 1995]SHOVE, P.; REPP, B. H. Musical motion and performance: Theoretical and empirical perspectives. The practice of performance: Studies in musical interpretation, p. 55-83, 1995.

[Spahlinger 2008]SPAHLINGER, M. this is the time of conceptive ideologues no longer. Contemporary Music Review, v. 27, n. 6, p. 579-594, 2008. ISSN 0749-4467.

[Steenhuisen 2004]STEENHUISEN, P. Interview with Helmut Lachenmann - Toronto, 2003. Contemporary Music Review, v. 23, n. 3, p. 9, 2004. ISSN 0749-4467. Disponível em: <http://www.informaworld.com/10.1080/0749446042000285591>.

[Stiegler 1998]STIEGLER, B. Technics and Time, 1: the Fault of Epimetheus. Stanford Calif.: Standford University Press, 1998. ISBN 0804730415. 
[Stockhausen 1996]STOCKHAUSEN, K. Electroacoustic performance practice. Perspectives of New Music, v. 34, n. 1, p. 74-105, 1996. ISSN 00316016.

[Stockhausen 2009]STOCKHAUSEN, K. Stockhausen e a Música. São Paulo: Mandras, 2009. ISBN 9788537003992.

[Sudnow 1979]SUDNOW, D. Talk's body: A meditation between two keyboards. 1st. ed. [S.l.]: Knopf, 1979. ISBN 0394502701.

[Sudnow 1993]SUDNOW, D. Ways of the hand. Cambridge, Massachusetts: MIT Press, 1993. 180 p. ISBN 0262691612, 9780262691611.

[Tarasti 1997]TARASTI, E. The emancipation of the sign: On the corporeal and gestural meanings in music. Applied Semiotics/Sémiotique appliquée, A Learned Journal of Literary Research on the World Wide Web, p. 176-265, 1997.

[Todes 2001]TODES, S. Body and World. Cambridge, Massachusetts: The MIT Press, 2001. ISBN 0262700824.

[Toop 1991]TOOP, R. Sulle Scale della Fenice. Perspectives of New Music, v. 29, n. 2, p. 72-92, 1991. ISSN 00316016. Disponível em: <http://www.jstor.org/stable/833431>.

[Toop 2004]TOOP, R. Concept and Context: a historiographic consideration of Lachenmann's orchestral works. Contemporary Music Review, v. 23, n. 3-4, p. 125-143, 2004 .

[Webb 2007]WEBB, B. Richard Barrett's 'Imaginary Trombone'. Contemporary Music Review, v. 26, p. 151-177, abr. 2007.

[Webern 1984]WEBERN, A. O Caminho para a Música Nova. São Paulo: Editora Novas Metas, 1984.

[Whittall 2005]WHITTALL, A. Resistance and Reflection: Richard Barrett in the 21st Century. The Musical Times, v. 146, n. 1892, p. 57-70, 2005. ISSN 00274666. 
[Wishart 1996]WISHART, T. On Sonic Art. Amsterdam: Harwood Academic Publishers, 1996. ISBN 3771865847X.

[Wittgenstein 1985]WITTGENSTEIN, L. The Blue and Brown Books: preliminary Studies of the 'Philosophical Investigations'. New York: Harper Torchbooks, 1985. ISBN 9780061312113.

[Wittgenstein 1991]WITTGENSTEIN, L. Philosophical Investigations: The German Text, with a Revised English Translation. Oxford: Wiley-Blackwell, 1991. ISBN 0631231277.

[Wittgenstein 1996]WITTGENSTEIN, L. Cultura e Valor. Lisboa: Ed. 70, 1996. ISBN 9789724409108 .

[Yung 1984]YUNG, B. Choreographic and kinesthetic elements in performance on the chinese Seven-String zither. Ethnomusicology, v. 28, n. 3, p. 505-517, set. 1984. ISSN 00141836. Disponível em: <http://www.jstor.org/stable/851237>.

[Zehentreiter 2006]ZEHENTREITER, F. Sensory congnition as an autonomous form of critique: Reflections on redefining a 'critical theory of art'. In: MAHNKOPF, C. (Ed.). Critical composition today. Hofheim: Wolke Verlag, 2006. ISBN 9783936000160. 